UNIVERSIDADE DE BRASÍLIA

INSTITUTO DE CIÊNCIAS HUMANAS

DEPARTAMENTO DE GEOGRAFIA - GEA

UMA ANÁLISE SOBRE A PRÁTICA PEDAGÓGICA DOS PROFESSORES DE GEOGRAFIA DO CEF-28 DE CEILÂNDIA

Antonio Dias da Silva

Brasília - DF: maio/2015 
UNIVERSIDADE DE BRASÍLIA

INSTITUTO DE CIÊNCIAS HUMANAS

DEPARTAMENTO DE GEOGRAFIA - GEA

UMA ANÁLISE SOBRE A PRÁTICA PEDAGÓGICA DOS PROFESSORES DE GEOGRAFIA DO CEF-28 DE CEILÂNDIA

Antonio Dias da Silva

Orientadora: Prof ${ }^{a}$. Dra. Cristina Maria Costa Leite

Dissertação de Mestrado

Brasília - DF: maio/2015 
Ficha catalográfica elaborada automaticamente, com os dados fornecidos pelo(a) autor(a)

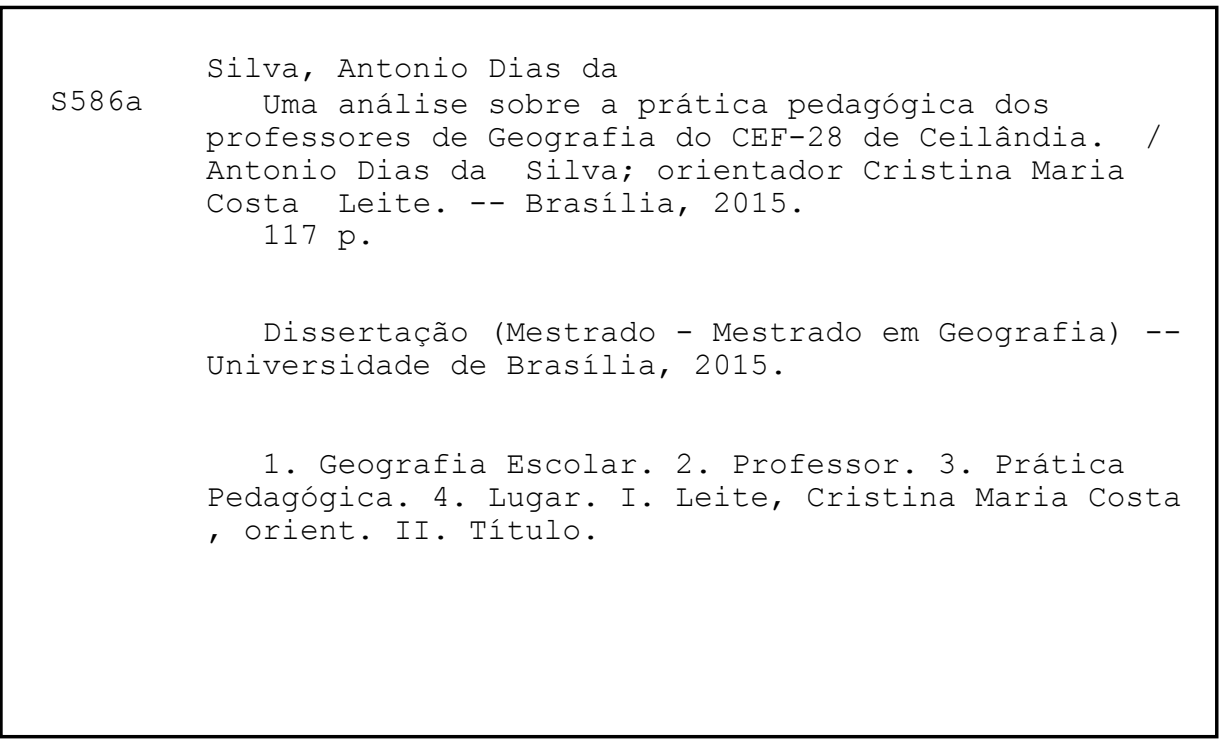




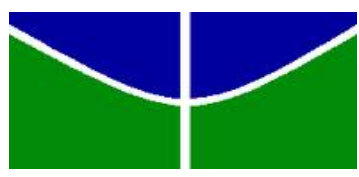

UNIVERSIDADE DE BRASÍLIA

INSTITUTO DE CIÊNCIAS HUMANAS

DEPARTAMENTO DE GEOGRAFIA - GEA

\title{
UMA ANÁLISE SOBRE A PRÁTICA PEDAGÓGICA DOS PROFESSORES DE GEOGRAFIA DO CEF-28 DE CEILÂNDIA
}

\author{
Antonio Dias da Silva
}

Dissertação de Mestrado submetida ao Departamento de Geografia da Universidade de Brasília, como parte dos requisitos necessários para obtenção do Grau de Mestre em Geografia.

Linha de pesquisa: Produção do Espaço Urbano, Rural e Regional.

Eixo Temático: Formação escolar geográfica e instrumentos educacionais.

Aprovado por:

Prof ${ }^{a}$ Dra. Cristina Maria Costa Leite, $(U n B)$

(Orientadora)

Prof ${ }^{a}$ Dra. Ercília Torres Steinke

(Examinadora Interno - Titular)

Prof ${ }^{-}$Dra. Antonia da Silva Samir Ribeiro

(Examinador Externo)

Profo Dr. Fernando Luiz Araújo Sobrinho

(Examinadora Interno - Suplente) 
In memoriam à Prof ${ }^{a}$ Paula Andrade, pela aprendizagem com ela alcançada. 
"Ninguém escapa da educação" e essa acontece "em casa, na rua, na igreja ou na escola" (BRANDÃO, 1985, p. 7). Por isso, dedico este trabalho a todos que participaram direta ou indiretamente de minha formação e me possibilitaram alçar voos e realizar sonhos. 
"Enfim, a geografia escolar não se ensina, ela se constrói, ela se realiza".

(CAVALCANTI, 2010). 


\section{AGRADECIMENTOS}

À Prof ${ }^{a}$ Dra. Cristina Maria Costa Leite, minha orientadora, que aceitou pegar em minhas mãos e nessa jornada acadêmica, carinhosamente me conduziu em um caminho, retirando as pedras que existiam.

À Prof ${ }^{a}$ Dra. Marli Sales, professora que deu os primeiros passos comigo nessa jornada na busca de realizar sonhos acadêmicos.

Aos professores que pertenceram à minha banca de seleção do Mestrado: Profo ${ }^{\circ}$ Dr. Everaldo Batista da Costa, Profo Dr. Fernando Luiz Araújo Sobrinho, Prof ${ }^{a}$ Dra. Marília Luiza Peluso por acreditar na relevância desta pesquisa e perceber a sua importância para o ensino de Geografia.

À toda equipe do Centro de Ensino Fundamental 28 de Ceilândia, palco da construção dessa investigação. Em especial à Diretora Glauce Kelly Novaes Scofield Furletti, ao ViceDiretor José Antônio Martins, ao Supervisor Pedagógico Josivaldo Oliveira Santos, Ao Secretário escolar Rander de Souza Ribeiro e todos que estiveram sempre dispostos a me auxiliar com informações e documentos internos da instituição.

Aos professores de Geografia do CEF-28 que contribuíram com a pesquisa.

À professora Rejane Alencar Domingos, que lutou por melhorias do CEF-28 de Ceilândia, registrando com fotografias as dificuldades enfrentadas no dia-a-dia e cobrando melhorias das autoridades competentes e me disponibilizou fotos de seu arquivo pessoal para agregar juntos as informações empíricas dessa pesquisa.

À todos os amigos e familiares por incentivar a continuação dos estudos e em especial à Itamar Araújo Morais e Sidinei Esteves de Oliveira de Jesus por incentivar a realização de um diálogo entre Lugar e ensino de Geografia.

A Leon dos Reis Costa Silva pela ajuda com a Língua Inglesa.

E incondicionalmente, a Lúcia Reis da Costa e Silva, por todas as contribuições e auxílio nos preenchimentos de lacunas da minha formação. 


\section{LISTA DE GRÁFICOS}

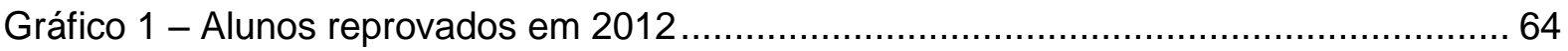

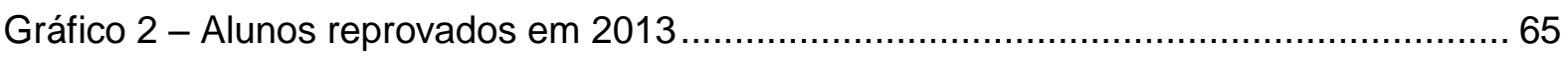

Gráfico 3 - Número de alunos desistentes....................................................................66 


\section{LISTA DE QUADROS}

Quadro 1 - Números de EPC's necessários para o Sol Nascente..................................... 52

Quadro 2 - Quantitativo de professores do CEF-28 nos anos de 2013 e $2014 \ldots \ldots \ldots \ldots \ldots \ldots . . . . . . .63$

Quadro 3 - Quantitativo de alunos por turmas do CEF-28 período de 2012 e 2013 ............ 63

Quadro 4 - Alunos ANEE e classes inclusivas do CEF-28 período de 2013 .......................63

Quadro 5 - Taxa de reprovação por série e disciplina 2013 .............................................6 66

Quadro 6 - Caracterização dos participantes da pesquisa ............................................. 67

Quadro 7- Conteúdos do PCN de Geografia para trabalhar Cidadania ............................... 80

Quadro 8 - Conteúdos do PCN de Geografia para trabalhar Lugar..................................... 82

Quadro 9 - Conteúdos do CM/EB-DF da disciplina de Geografia para trabalhar Cidadania e

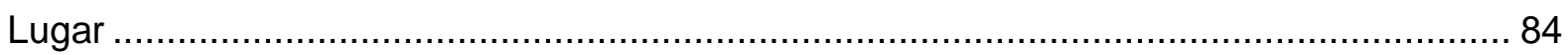

Quadro 10 - Conteúdos do PPP do CEF-28 de Ceilândia da disciplina de Geografia para

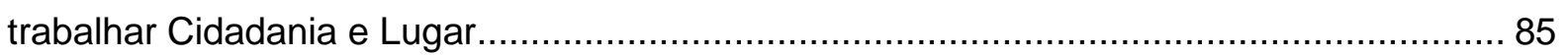

Quadro 11 - Conteúdos do PE dos professores de Geografia do CEF-28 de Ceilândia para

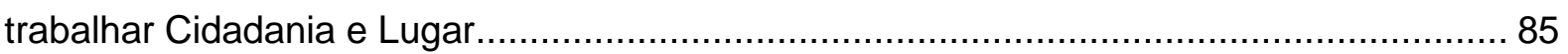

Quadro 12 - Cidadania e Lugar no LD escolhido pelos professores de Geografia do CEF-28

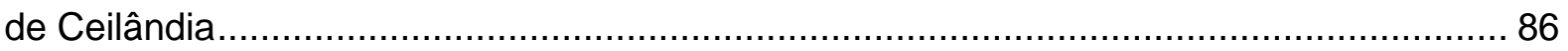

Quadro 13 - Respostas dos professores por grupo de perguntas dos questionários .......... 88

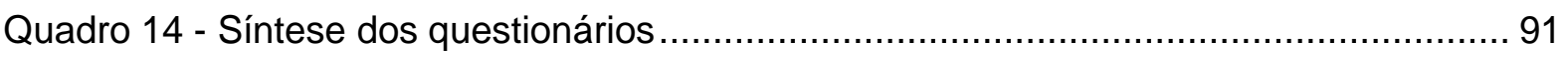

Quadro 15 - Respostas dos professores por grupo de perguntas das entrevistas...............93

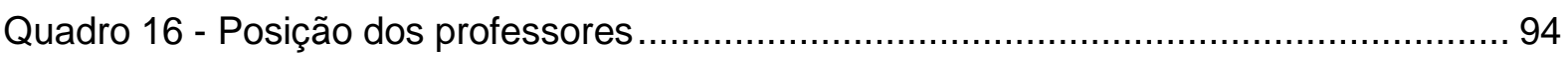




\section{Lista de Imagens}

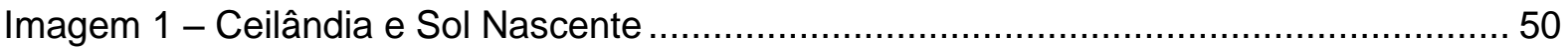

Imagem 2 - Futuro Laboratório de Informática do CEF-28 …......................................... 56

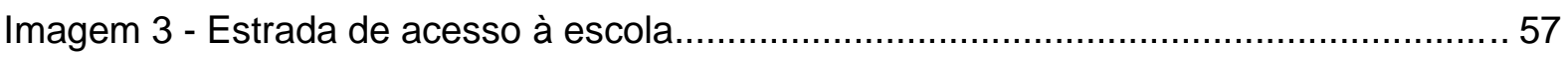

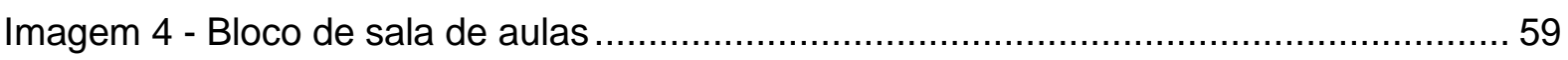

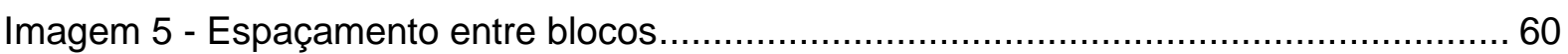

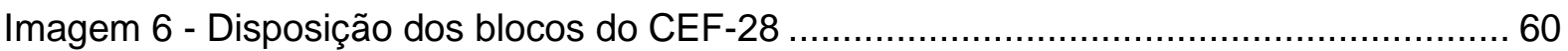




\section{Lista de Mapas}

Mapa 1 - Localização do CEF-28 na Ceilândia ........................................................... 53

Mapa 2 - Área e disposição do Centro de Ensino Fundamental 28 de Ceilândia ............... 61 


\section{Lista de Siglas}

ANEE - Alunos com Necessidades Educacionais Especiais

APAM - Associação de Pais, Alunos e Mestres

APM - Associação de Pais e Mestres

BIA - Bloco Inicial de Alfabetização

CEF - Centro de Ensino Fundamental

CEI - Companhia de Erradicação das Invasões

CMEB-DF - Currículo em Movimento da Educação Básica - Distrito Federal

CNAS - Conselho Nacional de Assistência Social

CODEPLAN - Companhia de Planejamento do Distrito Federal

DCSEE-DF - Diretrizes Curriculares da Secretaria de Estado e Educação-Distrito Federal.

DF - Distrito Federal

DPSEE/DF - Diretrizes Pedagógicas Secretaria de Estado de Educação do Distrito Federal

EAPE - Escola de Aperfeiçoamento dos Profissionais da Educação

EIA - Estudos de Impactos Ambientais

EPC's - Equipamentos Públicos Comunitários

GT's - Grupos de trabalhos

IBGE - Instituto Brasileiro de Geografia e Estatística

IE's - Instituições de Ensino

LD - Livro Didático

LDB - Lei de Diretrizes e Base da Educação

PCN's - Parâmetros Curriculares Nacionais

PCNEM - Parâmetros Curriculares Nacionais do Ensino Médio

PD - Pratica Diversificada

PDAF - Programa de Descentralização Administrativa Financeira

PDDE - Programa Dinheiro Direto na Escola

PE - Plano de Ensino

PNE - Plano Nacional de Educação

PPP - Projeto Político Pedagógico

QNP - Quadra Norte P

QNQ - Quadra Norte Q

SEAA - Serviço Especializado de Apoio à Aprendizagem

SEE-DF - Secretaria de Estado e Educação do Distrito Federal

TERRACAP - Companhia Imobiliária de Brasília

TGD - Transtorno Global de Desenvolvimento

UEx - Unidade Executora 
SILVA, Antonio Dias da (2015). Uma análise sobre a prática pedagógica dos professores de Geografia do CEF-28 de Ceilândia. Brasília: Dissertação de Mestrado, Universidade de Brasília.

\section{RESUMO}

Este estudo tem como objetivo compreender a prática pedagógica dos professores de Geografia do CEF-28 de Ceilândia, na perspectiva de entender se o ensino dessa disciplina cumpre com o papel da formação de cidadãos críticos, atuantes e conscientes do seu papel na sociedade e no lugar de sua vivência. A abordagem de compreensão do problema se fez através das teorias da Geografia Escolar e da Educação, passando pelas análises de documentos oficiais da Educação brasileira e do Distrito Federal. A pesquisa, de base qualitativa, foi realizada com questionários e entrevistas, cujos resultados apontam que a dinâmica do lugar, com suas particularidades sócio culturais e a ausência de uma política diferenciada para escolas em bairros com alta vulnerabilidade social, interfere diretamente no processo de gestão educacional, na prática pedagógica dos professores, e na aprendizagem dos alunos, evidenciando um ambiente pouco motivador à comunidade escolar. Diante das dificuldades enfrentadas pela equipe gestora e da falta de apoio diferenciado por parte da SEE-DF, os professores se sentem desmotivados, não se integram ao lugar e buscam outra escola para trabalhar, por meio de concurso de remoção interno ou externo. Em consequência, o rodízio de profissionais tem gerado dificuldades que apontam para descontinuidades e rupturas na construção do Projeto Político Pedagógico, que atendem aos anos finais, bem como de projetos educacionais na disciplina de Geografia, que poderiam ter, no lugar, uma via para o trabalho pedagógico. Os resultados obtidos pela pesquisa apontam, também, deficiências na formação dos professores, na medida em se constata uma prática pedagógica ainda tradicional, de um lado, e ausência de formação continuada no ambiente escolar. Esta prática solitária faz com os professores não se articulem coletivamente, distanciem-se não somente do seu coletivo escolar, como também da própria comunidade.

Palavras chaves: Geografia Escolar, Professor, Prática Pedagógica, Lugar. 
SILVA, Antonio Dias (2015). An analysis of the pedagogical practice of Geography teachers of CEF-28 Ceilândia. Brasília: Master's Thesis, University of Brasília.

\begin{abstract}
This study aims to understand the pedagogical practice of Geography teachers of CEF-28 Ceilândia as an attempt to understand wether the teaching of this discipline fulfills the role of forming critical citizens, active and aware of their role in society and in the space of their living experience. The approach of understanding of the problem was done through the theories of School Geography and Education, throughout the analysis of official documents of the Brazilian Education and of the Distrito Federal. The research, established on a qualitative basis, was conducted with questionnaires and interviews, which results show that the dynamics of the space, with its socio-cultural features and the lack of a differentiated policy for schools in neighborhoods with high social vulnerability, directly interfere in the education management, in the pedagogical practice of teachers, and the student learning, showing a low motivational environment to the school community. Given the difficulties faced by the management team and the lack of differentiated support from the SEE-DF, teachers feel discouraged, do not integrate the place where they teach and seek other schools to work, through a relocating administrative process. Consequently, the rotation of professionals has created difficulties that point to discontinuities and disruptions in the construction of Political Pedagogical Project designed for the final years, as well as educational projects in geography discipline, which could have, in the school space, a way to the pedagogical work. The results obtained from the research also indicate deficiencies in teacher formation, As it can be seen in the remaining traditional pedagogical practices carried out, on one hand, and lack of a continuous formation in the school environment on the other hand. This solo practice makes teachers do not operate collectively to alienate not only to its school community, as well as the community.
\end{abstract}

Keywords: School Geography, Teacher, Pedagogical Practice, Place. 


\section{SUMÁRIO}

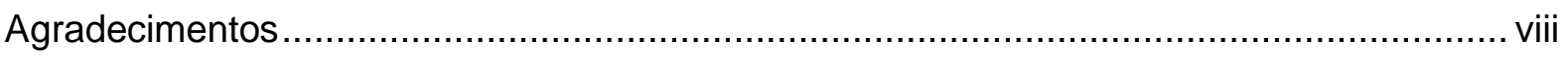

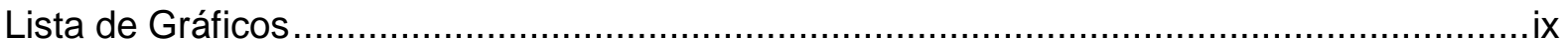

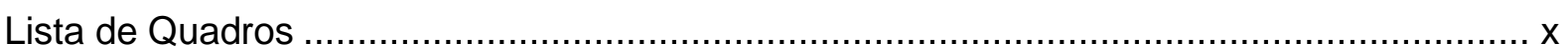

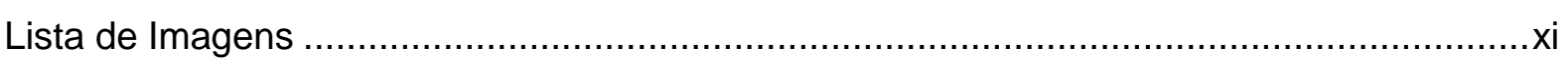

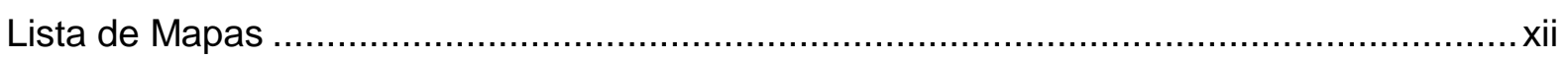

Lista de Siglas ..................................................................................................

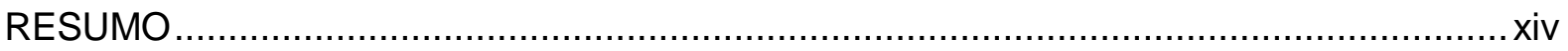

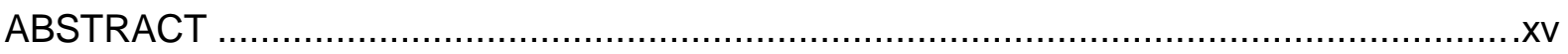

Introdução

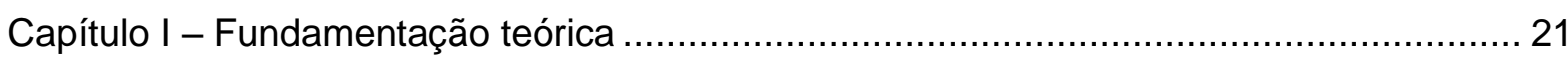

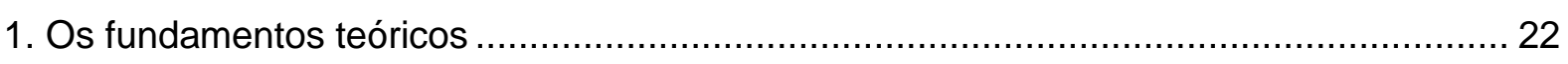

1.1 Ciência Geográfica, Geografia Escolar, Espaço Vivido, Conceito de Lugar e

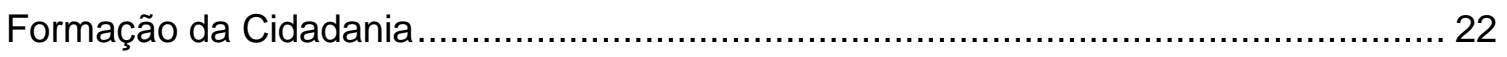

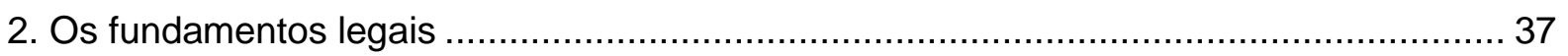

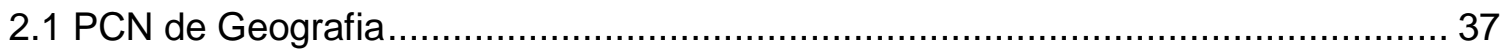

2.2 O Currículo em Movimento da Educação Básica do Distrito Federal/CMEB-DF .... 41

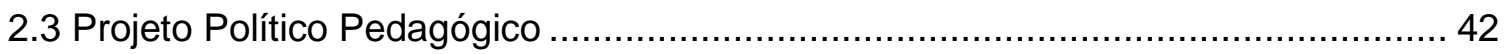

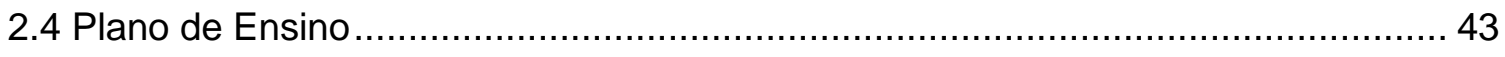

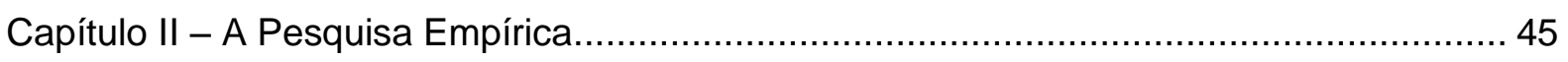

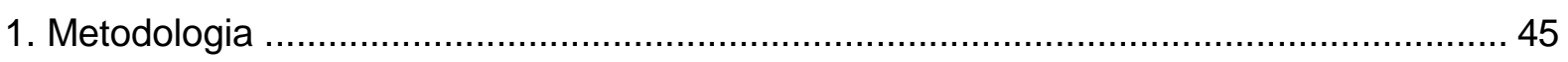

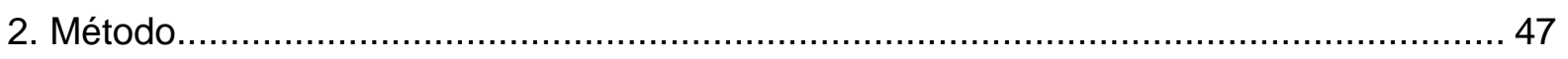

2.1 O contexto de construção das informações empíricas ....................................... 47

2.1.1 - O lugar da pesquisa: o Condomínio Sol Nascente, na Região Administrativa

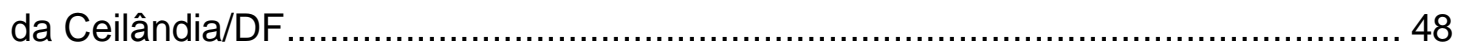

2.1.2 - O Centro de Ensino Fundamental 28 de Ceilândia ..................................... 52

2.1.3 - Participantes da pesquisa: os professores de Geografia do CEF- 28 e a sua

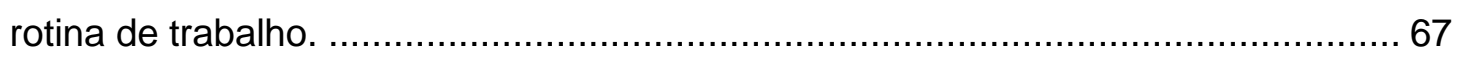

2.2 Procedimentos de construção das informações empíricas .................................... 71

2.2.1- Os questionários e as entrevistas ........................................................ 71

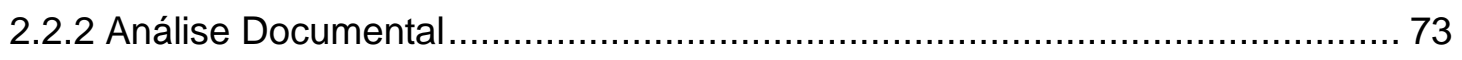

2.2.2.1 A organização dos conteúdos de Geografia no PCN .......................... 73

2.2.2.2 Organização e objetivos apresentado no Currículo em Movimento da Educação Básica do Distrito Federal/CM/EB-DF para a disciplina de Geografia74 2.2.2.3 Projeto Político Pedagógico/PPP do Centro de Ensino Fundamental/CEF28 de Ceilândia........................................................................................ 75 
2.2.2.4 Plano de Ensino dos Professores de Geografia do CEF-28................. 76

2.3 Procedimentos de análise das informações empíricas ......................................... 76

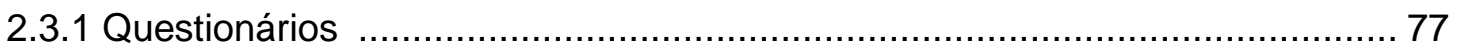

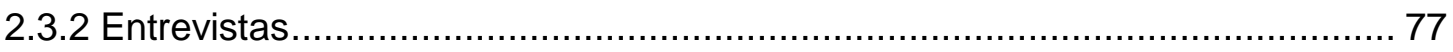

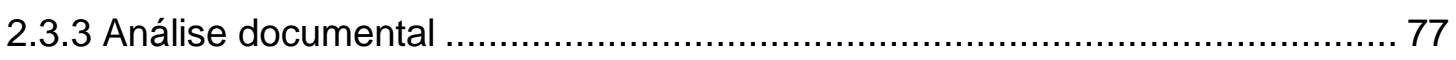

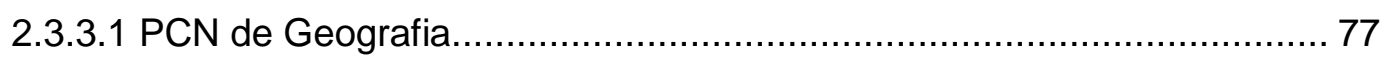

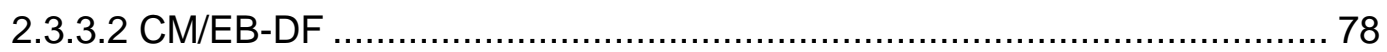

2.3.3.3 PPP do CEF- 28 de Ceilândia............................................................. 78

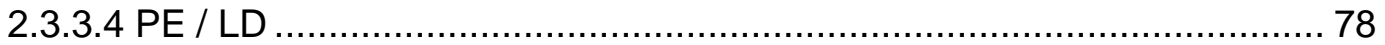

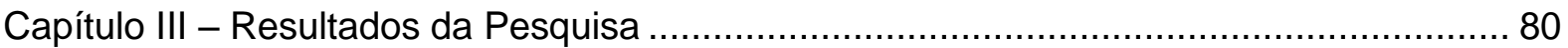

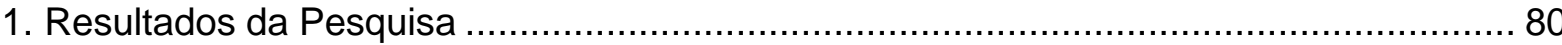

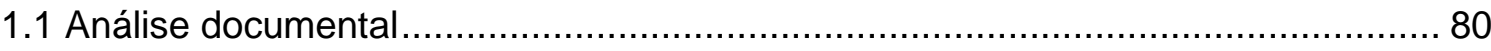

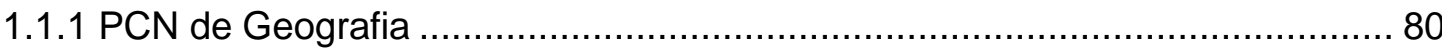

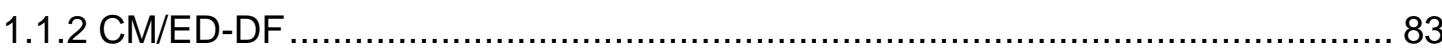

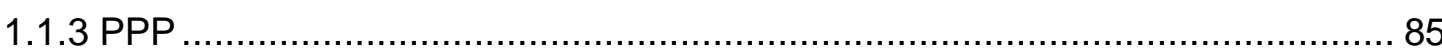

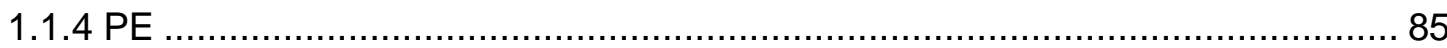

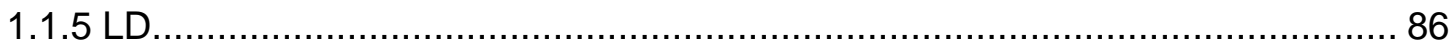

1.2 Organização das respostas e quadro síntese dos questionários ............................ 88

1.3 Sistematização e quadro síntese das entrevistas................................................ 92

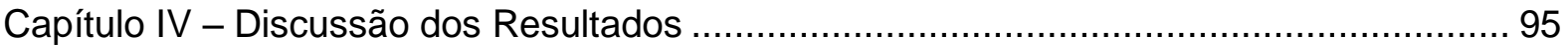

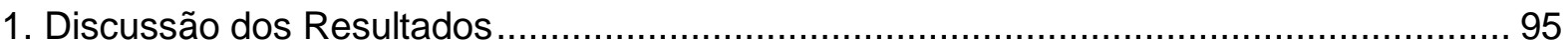

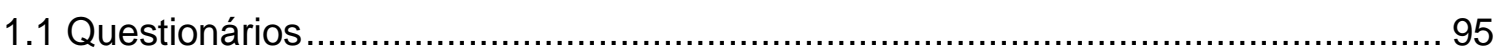

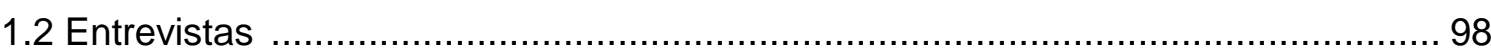

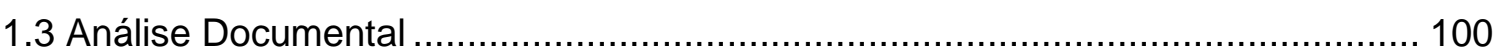

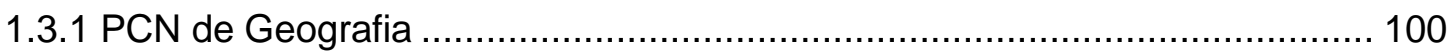

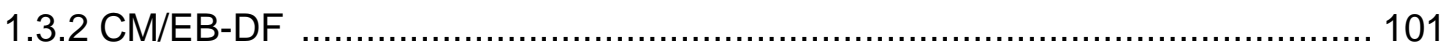

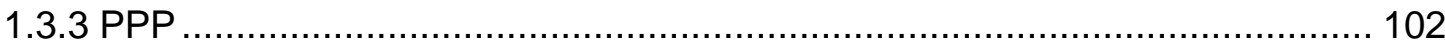

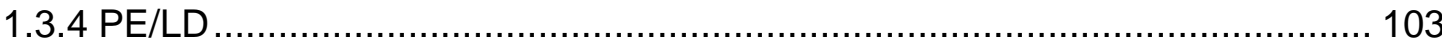

Considerações Finais e Recomendações ................................................................. 104

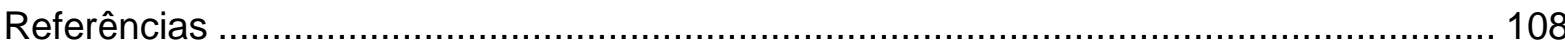

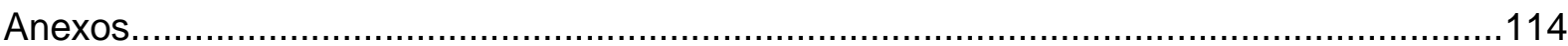




\section{Introdução}

O espaço Geográfico, que se encontra em constante transformação, expressa a história e as características da ação humana. Nesse sentido, constitui-se de relevante interesse para a pesquisa, não somente em relação à Ciência Geográfica, como também para formação de pesquisadores e professores na área.

Parte-se da premissa que espaço geográfico é o objeto comum entre a ciência Geográfica e a Geografia Escolar. A perspectiva escolar, entretanto, objetiva, também, a compreensão da vida cotidiana dos alunos, na esperança de que o indivíduo se perceba nas ações transformadoras do meio, como sujeito nas relações com o espaço geográfico e que adquira, ainda, a desenvoltura de refletir e opinar e, dessa forma, agir na realidade da sua comunidade.

A Geografia Escolar no Brasil está agregada a um contexto sócio, político, histórico, econômico e cultural de uma época e de uma sociedade. Portanto, o pensamento construído representa as expressões de cada época histórica. Desde a sua origem até a forma como se encontra hoje no currículo escolar, a Geografia contribui para a formação de mentalidades, a partir da compreensão do processo de produção do espaço geográfico, materializado nas relações entre sociedade/ natureza, conforme atestam os Parâmetros Curriculares Nacionais:

A Geografia tem por objetivo estudar as relações entre o processo histórico
na formação das sociedades humanas e o funcionamento da natureza por
meio da leitura do lugar, do território, a partir de sua paisagem. Na busca
dessa abordagem relacional, trabalha com diferentes noções espaciais e
temporais, bem como com os fenômenos sociais, culturais e naturais
característicos de cada paisagem, para permitir uma compreensão
processual e dinâmica de sua constituição, para identificar e relacionar
aquilo que na paisagem representa as heranças das sucessivas relações no
tempo entre a sociedade e a natureza em sua interação. (PCN DE
GEOGRAFIA,1998, p. 26).

Ao analisar a finalidade da Geografia Escolar percebe-se o aumento de sua importância no contexto escolar diante das necessidades de enfrentamento de questões complexas, tais como a diversidade, desigualdade socioeconômica, étnica e religiosa, que caracterizam a contemporaneidade. Nessa perspectiva, o ensino de Geografia possibilita promover o conhecimento das pluralidades culturais, desconstruindo preconceitos e 
predisposições contra os diversos grupos sociais, o que the confere reconhecido mérito, notadamente no que se refere à formação dos indivíduos.

Assim, esta pesquisa expressa os questionamentos de um professor da Educação Básica, da Secretária de Educação do Distrito Federal, com nove anos de exercício da função de magistério, no âmbito do Ensino Fundamental e Médio. A experiência obtida nesse percurso permitiu a constatação de que os alunos sentiam-se pouco motivados com as aulas de Geografia, demonstrando seu descontentamento com reclamações e alto índice de reprovações.

Tal situação desencadeou questionamentos referentes ao porque da rejeição à disciplina de Geografia. Nesse sentido, esses questionamentos desdobraram-se no projeto de pesquisa ora apresentado com a seguinte problemática: o ensino de Geografia cumpre seu papel na formação dos alunos, possibilitando a construção de conhecimentos necessários à formação da cidadania?

A suposição que norteia esta investigação é que a disciplina Geografia não cumpre com seu papel formativo. Nesse sentido, supõe-se que os resultados a serem obtidos nesta investigação, comprovarão que a prática dos professores de Geografia ainda se encontra numa perspectiva tradicional, em desacordo com as orientações estabelecidas pelos documentos oficiais. Tal suposição possibilita construir alguns questionamentos, cujas respostas serão apresentadas ao final desta pesquisa, a saber:

- Papel da Geografia na formação dos alunos;

- Importância da Geografia para os alunos;

- Problemas nas relações de ensino/aprendizagem em Geografia:

- Inserção do lugar no contexto de suas aulas;

- Material de consulta para elaboração de plano de ensino;

- Avaliação do aluno;

- Utilização do livro didático;

- Trabalhos de campo.

O objetivo geral desta investigação é analisar o papel da Geografia Escolar na prática pedagógica dos professores dessa área. Assim, esta pesquisa analisará a prática docente dos professores da disciplina de Geografia do $6^{0}$ ao $9^{\underline{a}}$ ano, do Centro de Ensino Fundamental 28 de Ceilândia, no sentido de identificar se seu papel para a formação cidadã 
vem sendo cumprido. Nessa linha de raciocínio, pretende-se verificar e analisar se os professores dessa disciplina atendem as expectativas de aprendizagem estipuladas por documentos oficiais - Parâmetros Curriculares de Geografia/PCN para o Ensino Fundamental; Diretrizes Curriculares da Secretaria de Educação para a disciplina de Geografia/DCSEE-DF; PPP da escola; e Planos de Ensino da disciplina. Tal intenção fundamenta os objetivos específicos desta pesquisa, a saber:

- Analisar o papel do componente disciplinar Geografia nos documentos oficiais;

- Relacionar os pressupostos teóricos para o ensino de Geografia com a prática docente para o CEF-28 de Ceilândia.

- Identificar e analisar como os professores de 6ํㅡㅁ ao ano trabalham os conteúdos de Geografia;

- Analisar se os professores estabelecem relações entre o conteúdo ministrado e a realidade vivida pelos alunos.

Para o alcance dos objetivos desta pesquisa foi utilizada uma abordagem qualitativa, a partir de análise documental dos - Parâmetros Curriculares Nacionais de Geografia/PCN de Geografia, Currículo em Movimento da Educação Básica do Distrito Federal/CM/EB-DF, Projeto Político Pedagógico do Centro de Ensino Fundamental 28 de Ceilândia/PPP CEF28, Plano de Ensino/PE-, questionários mistos e entrevistas semiestruturadas com os professores do CEF-28 de Ceilândia. 


\section{Capítulo I - Fundamentação teórica}

"[...] o lugar é a vida cotidiana: o cotidiano é o lugar do desejo, do sentido, contrapondo com a necessidade, a ordem distante". (CAVALCANTI, 2008, p. 31).

A intenção de estudar o papel da Geografia no âmbito da escolarização do CEF 28 de Ceilândia exige a necessidade de articulação de aportes teóricos distintos e complementares: Geografia e Educação. Assim, a delimitação do campo de pesquisa foi efetuada em função do acesso e disponibilidade de bibliografia compatível com os objetivos desta investigação.

Os fundamentos teóricos que norteiam as discussões relativas à Geografia apoiamse em Pontuschka, Paganelli \& Cacete (2007), Callai (2005), Cardoso \& Medeiros (2009), Cavalcanti (2006, 2008, 2011 e 2012), Leite (2011), Pontuschka (2007, 2013), Vesentini (2004).

No que se refere à Educação, os fundamentos são de Freire (1982, 1997), Gôngora (1985), Libâneo (1994), Piletti (1990), Saviani (1987) e Veiga (2000), além dos dispositivos legais existentes, a saber: Parâmetros Curriculares Nacionais (1997), Currículo em Movimento do Distrito Federal (2013), Projeto Político Pedagógico e Plano de Ensino. Assim, os fundamentos que se seguem, explicitam as considerações desses dois campos de conhecimento, que se articulam a partir do ensino de Geografia.

Tais fundamentos estruturam-se em dois tópicos básicos: o primeiro efetua uma breve síntese histórica da ciência geográfica e suas relações com o ensino de Geografia, inseridas no prisma das vertentes pedagógicas vigentes. A partir dessa retrospectiva, apresenta-se a perspectiva crítica para o ensino de Geografia, pano de fundo para a discussão dos conceitos de lugar, espaço vivido e formação da cidadania. Num segundo momento, sintetizam-se as proposições dos PCN's para a formação da cidadania e a valorização do lugar, no sentido de verificar onde os documentos oficiais, que legitimam novas práticas na escolarização em geografia, indicam a perspectiva do lugar, categoria de análise do espaço geográfico, do espaço vivido e da formação da cidadania. Importante ressaltar que tais fundamentos, teóricos e legais, objetivam demonstrar como o ensino de Geografia apresenta estreita relação com a formação da cidadania. 


\title{
1. Os fundamentos teóricos
}

\subsection{Ciência Geográfica, Geografia Escolar, Espaço Vivido, Conceito de Lugar e Formação da Cidadania}

Esta sessão apresenta, inicialmente, considerações acerca das relações entre o desenvolvimento do pensamento geográfico e o ensino da Geografia na escola básica. Nessa perspectiva, e a partir de uma abordagem histórica, pontua questões referentes ao processo didático-pedagógico na esfera dos objetos, das técnicas e da metodologia do ensino desta disciplina. Posteriormente, direciona-se o olhar sobre o ensino de Geografia pelo prisma de sua vertente crítica, a partir da qual se analisam as relações com o conceito de lugar, o espaço vivido e a formação da cidadania.

Ao pesquisar sobre a história da Geografia, enquanto disciplina no currículo das escolas públicas, percebe-se que existem poucas pesquisas nessa área. Esta constatação é feita por Rocha, que afirma:

\begin{abstract}
A história da Geografia escolar brasileira, tem sido sistematicamente relegada a segundo plano pela comunidade acadêmica, a mesma comunidade que tem buscado amiúde intervir nos rumos dados ao ensino desta disciplina, com um claro intuito de sanar os problemas por ela apresentados, sem, porém, buscar a fundo desvelar as origens destes problemas. Até mesmo os(as) próprios(as) educadores(as) que atuam com o ensino desta disciplina, pouquíssimo têm se preocupado com essa questão. É como se esta disciplina (bem como as demais) não fosse dotada de história. (ROCHA, 1996, p. 23).
\end{abstract}

O saber geográfico surge em decorrência do próprio processo de organização do homem em sociedade, com fins práticos, de solucionar problemas imediatos tais como: localização de seres, objetos, ou lugares em seu entorno e identificar os perigos e potenciais de uso da natureza (ROCHA, 1996). No caso brasileiro, a Companhia de Jesus, de padres jesuítas, contribuiu com a construção da educação escolar, que foi implantada por volta de 1599. Nesse contexto, os jesuítas ensinavam saberes considerados geográficos, pautados no conhecimento e utilização dos recursos naturais existentes no território. Assim, pode-se deduzir, que os Jesuítas, não somente, se utilizavam de informações consideradas geográficas, como também, faziam uso de conceitos da área, conforme atesta Rocha:

Ressalte-se, porém que não interessou aos jesuítas, até por causa de seu currículo internacionalista, falar em suas aulas de uma geografia brasileira (seja desenvolvendo um estudo descritivo da colônia de então, seja trabalhando uma cartografia local). Inaugurava-se com eles, também, o ensino que somente se propunha a falar da geografia produzida por outros 
povos, característica tão marcante assumida por esta disciplina no Brasil. (ROCHA, 1996, p. 136).

Portanto, por todo o período de atuação da educação jesuítica no Brasil, saberes considerados geográficos permeavam o currículo e se manifestavam pelos conteúdos referentes à descrição de outros povos, outras culturas, descrição dos locais, regiões e território.

Somente por volta de 1817 é que a Geografia aparece como um saber escolar, a despeito de ainda não estar legitimada como campo científico, fato esse que ocorreria anos mais tarde, em 1870, na Alemanha. Assim, seu início no âmbito escolar é decorrente da publicação, pela Imprensa Régia, do Compêndio Elementar de Geographia Especial do Brasil (Sousa Neto, 2000), que foi adotado pelas escolas, caracterizando o que seria o ensino de geografia.

Este livro foi utilizado por aproximadamente um século, por professores que atuavam na disciplina. Nesse sentido, em todo o período que esse livro se constituiu suporte ao ensino de geografia, constata-se a ocorrência de uma perspectiva considerada tradicional, na medida em que os conteúdos referiam-se à descrição das paisagens naturais brasileiras.

O ensino de Geografia adquiriu estatuto de disciplina autônoma e com maior importância, somente em meados do século XIX, após a criação do Colégio Imperial Pedro II, nas cidades do Rio de Janeiro, Niterói e Duque de Caxias. Com influência da escola francesa de Geografia, o modelo implantado naquele colégio tinha como objetivo a formação de uma elite nacional, pois a maioria dos alunos, na época, representava a elite econômica e política do país. Tal situação só foi alterada após o manifesto dos pioneiros em 1932, que resultou na elaboração de anteprojetos ao capítulo da educação, para a nova Constituição e, também, o esboço para um plano nacional da educação com proposta de universalizar a educação (PAGNI, 2000).

Após ter se tornado uma ciência autônoma, a Geografia chega ao final do século $X X$ com considerações renovadas, ou seja, superação do positivismo como fundamento filosófico e novas possibilidades de análise, estabelecidas no materialismo históricodialético, na fenomenologia, entre os mais significativos. Nesse contexto, a repercussão em ambiente escolar evidencia-se pela consideração da realidade vivida pelos alunos, pela compreensão das relações sociedade/natureza e a interligação entre ambas. Importante ressaltar que no longo período de evolução da geografia, como campo científico do saber, 
essa área sempre buscou a construção de fundamentos epistemológicos necessários à consolidação de sua cientificidade.

A consolidação da Geografia como ciência no Brasil, teve uma trajetória marcada por distintas correntes de pensamento, que repercutiram no modo pelo qual a Geografia era ensinada nas escolas, a saber: Determinismo Ambiental, Possibilismo, Regional, Teorética Quantitativa e Crítica. Tais vertentes de pensamento serão sintetizadas a seguir.

A primeira vertente do pensamento geográfico, denominada Determinismo Ambiental, tem como representante principal Friedrich Ratzel. Esse autor concebeu a ideia do espaço vital, cuja apropriação pelo Estado alemão contribuiu para justificar o expansionismo alemão. Por esse prisma, o homem é considerado produto do meio e as condições naturais de um território influenciam a fisiologia e a psicologia humana. Daí a afirmação de que essas condições determinariam as condições de desenvolvimento de progresso de uma dada localidade (GALVÃO \& BEZERRIL, 2013).

A segunda vertente do pensamento geográfico é denominada possibilismo e tem Paul Vidal de La Blache como um de seus maiores representantes. A denominação dessa vertente é explicada pelo historiador Lucien Febvre:

[...] para discernir a geografia francesa dos trabalhos influenciados pelo determinismo ambiental. Assim, o termo passou a designar uma escola de pensamento que encara o ambiente natural como um mero fornecedor de possibilidades para a modificação humana, não determinando a evolução das sociedades, sendo o homem o principal agente geográfico (DINIZ FILHO, 2009, p. 84-87).

Nessa vertente considera-se que a natureza exerce influência relativa sobre o homem, na medida em que ele detém a possibilidade de escolher e modificar o ambiente natural, conforme suas necessidades. La Blache contrapunha-se ao pensamento determinista defendido por Ratzel e, em consequência, suas ideias tinham, também, o propósito de combater a escola alemã e justificar o colonialismo afro-asiático francês.

Posteriormente, a Geografia começa se enquadrar na corrente denominada Regional, tendo Richard Hartshorne como um dos seus principais representantes. A ele é atribuído a transição para a renovação na Geografia (MORAES, 1990). Esta vertente do pensamento surgiu na Europa e nos Estados Unidos e recebeu atenção dos estudiosos desde o século XVIII e XIX. Entretanto, somente a partir da década de 1940, ganhou maior evidência. Hartshorne realiza um estudo particularizado de cada área, que se constitui a 
própria regionalização, ou seja, é preciso criar uma geografia de nível regional para saber o potencial de cada região, para melhor explorá-la.

É nesse contexto que a Geografia alcança seu lugar na educação escolar no Brasil, com a criação do curso superior de Geografia na Faculdade de Filosofia, Ciências e Letras da Universidade de São Paulo, em 1934. O curso teve colaboração dos professores Pierre Monbeig e Pierre Defontaines, geógrafos franceses, formados sobre a influência da vertente Possibilista. Em consequência, a consolidação da Geografia neste período foi marcada pela fundamentação filosófica positivista, que sustentava epistemológica e metodologicamente quase todos os cursos, estudos e pesquisas da área de ciências humanas deste período, nas universidades brasileiras. Esta geografia, embasada no positivismo e Lablachiana, foi denominada a partir dos anos 1970, como Geografia Tradicional, pois se pautava nos estudos das populações e dos homens como coisas objetivas, nas quais a sociedade e o espaço emergiam das ações humanas desprovidas de quaisquer intencionalidades ou ideologias (MORAES, 1990).

Nessa sequência temporal a Geografia Teórico-Quantitativa surge a partir da necessidade de reconstrução econômica dos países destruídos pela Segunda Guerra Mundial. Nesse sentido, os geógrafos buscam formulações para superar a crise econômica capitalista. Importante destacar que essa corrente efetua críticas à Geografia Tradicional, por considerá-la insuficiência à análise dos problemas que emergiam no pós-guerra.

Segundo Wettstein (1992, p. 11): "A Geografia Quantitativa baseou-se na formulação matemática dos raciocínios e alcançou alto grau de formalização, graças à utilização de métodos matemáticos". Desta forma, se apropriou das tecnologias e substituiu o trabalho de campo pelos experimentos laboratoriais, mensurações, dados estatísticos, gráficos e tabelas bastante sofisticadas. Nessa vertente as linguagens matemáticas e estatísticas constituíamse o principal caminho para se chegar a comprovação de hipóteses, esclarecer e explicar a ocorrência dos fenômenos geográficos.

O ensino de Geografia, em termos da educação básica, derivado e embasado na perspectiva Tradicional se pautava pelos estudos descritivos das paisagens naturais e humanizadas, sendo dissociada dos sentimentos dos homens pelo espaço. E Leite, (2002, p. 258) ainda afirma que este "teve ampla ressonância em termos da Geografia ensinada nas escolas, o mesmo não pode ser afirmado em relação às vertentes críticas". 
$\mathrm{Na}$ perspectiva Tradicional a metodologia didática utilizada pelos professores enfatizava a descrição e a memorização dos elementos da paisagem, como dimensão observável do território e do lugar (Rocha, 1996). Essa metodologia caracterizava-se pela tendência liberal tradicional na qual a sociedade capitalista sustenta(va) a ideia de que o aluno deve ser preparado para os papéis sociais de acordo com suas aptidões. $\mathrm{Na}$ educação o professor é a figura central e o aluno é um receptor passivo do processo educativo.

A educação tradicional permaneceu por anos e, até hoje, muitos educadores ainda se encontram ancorados nessa perspectiva. Ou seja, ainda são encontrados profissionais que consideram o professor como detentor do saber, com a função de transmitir informações e onde o aluno é, apenas, um mero receptor da informação, que deve receber e memorizar as informações que Ihe são repassadas. Nesse contexto as avaliações servem, tão somente, para medir a quantidade de informações que o aluno conseguiu absorver. Tal situação, considerada o caminho em direção do saber, é pontuada por Gôngora:

O caminho cultural em direção ao saber é o mesmo para todos os alunos, desde que se esforcem. Assim, os menos capazes devem lutar para superar as dificuldades e conquistar um lugar junto aos mais capazes. Caso não consigam, devem procurar um ensino mais profissionalizante. (GÔNGORA, 1985, p. 23).

Assim, pode-se afirmar que a existência dessa situação caracteriza a educação numa perspectiva tradicional e conservadora. Saviani (1987) avança nessa análise ao dividir as concepções fundamentais da filosofia da educação em períodos

[...] até 1930 - predomínio da tendência 'humanista' tradicional; de 1930 a 1945: equilíbrio entre as tendências 'humanista' tradicional e 'humanista' moderna; de 1945 a 1960: predomínio da tendência 'humanista' moderna: de 1960 a 1968: crise da tendência 'humanista' moderna e articulação da tendência tecnicista; a partir de1968: predomínio da tendência tecnicista e a concomitante emergência de críticas à pedagogia oficial e à política educacional que busca implementá-la. (SAVIANI, 1987, p. 33).

De acordo com esse autor, esses períodos não se constituem fases homogêneas, nem tampouco fixas. Por isso pode-se perceber sua ocorrência nos dias atuais, na prática e nas concepções pedagógicas de muitas instituições e professores. A periodização estabelecida por Saviani é interessante para mostrar que as ocorrências no âmbito da Geografia eram plenamente compatíveis com as perspectivas educacionais vigentes. 
Retomando-se a evolução da geografia, pode-se afirmar que por volta dos anos 1970, surgiu a Geografia Crítica, fundamentada no materialismo histórico-dialético. Seus principais teóricos foram o francês Yves Lacoste e no Brasil, Milton Santos. A Geografia Crítica ficou conhecida como a geografia do mundo subdesenvolvido e, de um modo geral, postula que essa situação é decorrente de um processo histórico, da situação de colônia, no passado, e da economia periférica no presente. Na perspectiva daqueles autores o conhecimento científico deve servir como via para mudar a situação vigente.

No que se refere à educação, a partir da década de 1980 e logo após o período de redemocratização política no Brasil, ocorrem transformações nos métodos e nas metodologias de ensino, atingindo todas as áreas do conhecimento. Nesse sentido, a transformação dos conceitos de concepção da sociedade, os métodos pedagógicos tradicionais e as teorias descritivas da Geografia Tradicional tornaram-se insuficientes para apreender a complexidade do espaço geográfico. Tal situação se insere num contexto, onde a escola assume um novo papel, conforme explicita Leite:

\begin{abstract}
Neste contexto a escola constitui-se um meio para aquisição de conhecimentos e habilidades, num empreendimento educacional que inculca crenças, habilidades e sentimentos, a fim de transmitir e explicar as formas de interpretar o mundo natural e social de sua cultura patrocinadora. Assim, a escola e o processo de escolarização assumem relevante papel nas interpretações que cada pessoa constrói sobre si, sobre o outro, sobre o mundo. No desempenho dessa função, porém, a escola pode incorrer no risco de estabelecer uma determinada versão de mundo. Entretanto, esse risco é necessário para superar a estagnação e alienação, uma vez que uma educação eficaz corre riscos ao fomentar a flexibilidade. (LEITE, 2011, p. 4).
\end{abstract}

Nesse novo panorama a educação é concebida diante do desafio de corroborar com a formação de educandos. Assim, propõe conceber a realidade em todas suas complexas relações de causa e efeito, com a intenção de organizar as capacidades dos sujeitos, para que possam cumprir e assumir papéis na construção de uma sociedade mais justa e igualitária.

Diante do exposto, até o momento, pode-se constatar o panorama geral sobre o qual se assentam novas proposições para o ensino de Geografia. Desse modo, torna-se necessário explicitar a perspectiva da Geografia Crítica e suas contribuições para a formação do pensamento geográfico escolar, em contraposição às vertentes da Geografia Tradicional, de fundamentação positivista. Para isso, serão apontadas algumas considerações relativas à educação, entre as quais se destaca a psicologia interacionista de Vygotsky, que forneceu elementos importantes à proposição de metodologia de ensino- 
aprendizagem, com implicações na formação de cidadãos atuantes e conscientes de seu papel na sociedade.

A herança dos conceitos vinculados às vertentes que cunham a Geografia Tradicional, por vários anos produziu obstáculos à elaboração de uma geografia voltada para a construção da cidadania, perspectiva contemporânea dessa área em relação ao conhecimento escolar. Nesse sentido, é somente no contexto dos anos 1960-1970, que emerge a vertente crítica na Geografia, como possibilidade de atender aos questionamentos que se impunham naquele período. As produções geográficas anteriores a essa época apresentavam uma pseudo neutralidade e excluíam a problemática social, sob o entendimento de que tais temas não eram geográficos, além de não se enquadrarem nos pressupostos do método positivista. Em consequência, revelavam-se os interesses políticosideológicos das classes dominantes, uma vez que a geografia produzida ao identificar, localizar, quantificar e representar os recursos naturais existentes no território, indicando seus potenciais de uso e ocupação, explicitava as próprias bases de reprodução capitalista (Rocha, 1996).

A Geografia Crítica surge da necessidade de uma análise crítica das realidades sociais, sustentadas tacitamente para as finalidades sociopolíticas da educação. Nesse contexto, o prognóstico essencial para a transformação conceitual e epistemológica do saber geográfico fundamenta-se na criticidade e na elaboração de um novo saber, como afirma Vesentini

[...] criticidade entendida como uma leitura do real - isto é, do espaço geográfico - que não omitia as suas tensões e contradições, tal como fazia e faz a geografia tradicional, que ajude a esclarecer a espacialidade das relações de poder e de dominação. E engajamento visto como uma geografia não mais "neutra" e sim comprometida com a justiça social, com a correção das desigualdades socioeconômicas e das disparidades regionais. (VESENTINI, 2004, p. 223).

Desse modo, a perspectiva da Geografia crítica na escola vai se consolidando a partir da década de 1980, conforme atesta Cavalcanti:

Neste momento de renovação do ensino de Geografia - na década de 1980, como já se disse, predominavam ideias de caminhos alternativos que se orientavam pelo marxismo, ou pelo materialismo dialético -, questionavase a estrutura dicotômica e fragmentada (composta por "partes estanques") do discurso da geografia (de um lado, apresentavam-se os fenômenos naturais; de outro, os humanos), e algumas propostas buscavam inserir nesse discurso elementos da análise espacial. Mas do que localizar e descrever elementos da natureza, da população e da economia, de forma 
separada e dicotomizada, propunha-se uma nova estrutura para esse conteúdo escolar, que tivesse como pressupostos 0 espaço e as contradições sociais, orientando-se pela explicação das causas e decorrências das localizações de certas estruturas espaciais. (CAVALCANTI, 2008, p. 23).

Tal perspectiva associada à educação manifesta-se pelo esclarecimento dos conceitos da espacialidade, das relações de poder e dominação e também de uma visão crítica da justiça social. Tais temáticas foram fundamentais à análise da tendência históricocritico. Tal tendência surgiu no Brasil nos fins dos anos 1970 e salientava a prioridade focar os conteúdos no seu cotejo com as realidades sociais. Tal concepção influenciou o ensino de Geografia, na medida em que, a partir desse período, ganhou conteúdo político, que contribuiu para a significação do conceito de cidadania. Em consequência, abriram-se novas possibilidades de (re)interpretar os conceitos de espaço, território e paisagem.

$\mathrm{Na}$ perspectiva de Leite (2011, p. 03) diante dos desafios impostos à educação, exige-se do docente um trabalho que fuja das metodologias de ensino tradicionais e que sejam compatíveis com a formação do sujeito no século XXI, notadamente no que se refere às características da contemporaneidade, onde se destacam o processo de globalização da economia e a ampliação das desigualdades sócioespaciais.

Nesse contexto, a educação encontra-se diante da necessidade de encontrar novos caminhos: caminhos que atribuam significados ao processo de ensinar e aprender e que possibilitem a construção do conhecimento. Tal perspectiva, aplicada ao ensino de geografia, se traduz pelas palavras de Cavalcanti:

[...] o primeiro passo é colocar o aluno como centro e sujeito do processo de ensino, para, a partir daí, refletir sobre o papel do professor e da Geografia, que são elementos igualmente fundamentais no contexto didático. (CAVALCANTE, 2008, p. 35).

Assim, a geografia escolar é um trabalho investigativo, conforme enunciam Pontuschka, Paganelli \& Cacete (2007):

A perspectiva de trabalhar de forma investigativa pressupõe uma mudança de atitude perante ao conhecimento. Significa ultrapassar a visão da prática pedagógica como simples transmissão de conhecimento pronto e acabado que os alunos não possuem e implica outra concepção de educação, de acordo com a qual o conhecimento é visto a luz de seu processo de produção e apropriação, como um produto social de contextos históricos determinados - revelando-se, portanto, algo provisório, em permanente processo de construção e reconstrução (PONTUSCHKA, PAGANELLI \& CACETE, 2007, p.98). 
Este processo, de construção e reconstrução do conhecimento, trouxe grandes desafios para a prática pedagógica, onde se destacam: a questão da formação do professor nas universidades; a produção de materiais e livros didáticos; a necessidade de organização curricular e seleção dos conteúdos; as transformações nas concepções de práticas pedagógicas dos professores em sala de aula e no processo avaliativo.

Tais desafios situam-se num contexto de redes de comunicação tecnológica, com a decorrente globalização da economia, que desencadeou uma padronização de consumo. Desse modo, as tecnologias da comunicação e da informação, que permitem presenciar simultaneamente, instantaneamente e assincronamente fenômenos e acontecimentos em escala mundial, favorecem um processo de homogeneização cultural, pelo fato do consumo estar sendo padronizado em escala mundial. Em consequência, ampliam-se as desigualdades socioespaciais, com agravamento de alguns problemas tais como: exclusão social, desigualdade socioeconômica, violência, fragmentação territorial, conflitos socioambientais, desemprego entre outros (LEITE, 2011).

Nesse cenário de mundo globalizado merece destaque o processo de urbanização, que representa uma das características mais contundentes da contemporaneidade. No caso brasileiro, por exemplo, as cidades abrigam aproximadamente $84 \%$ da população (IBGE, 2010), com forte presença do multiculturalismo, intensificado pelas tecnologias de comunicação e o convívio urbano, que enriquece a vida cotidiana, tornando-a lugar de manifestações globais e universais. Nesse sentido, Cavalcanti (2008, p. 17), apropriadamente afirma que estas manifestações "constituem-se lugares de encontros, lugares de diferenças".

Tais considerações, sucintas, sobre a contemporaneidade objetivam introduzir a temática referente ao ensino de Geografia, no sentido de que essa área do conhecimento assume relevada importância na formação de um cidadão que é mundial e local ao mesmo tempo. Assim, o ensino de Geografia assume uma perspectiva de compreensão do espaço na sua historicidade e na relação dialética com a sociedade. Nesse prisma a Geografia Escolar dispõe de uma postura crítica, que revela um descontentamento sobre práticas tradicionais de ensino. Numa perspectiva tradicional, essa disciplina não atraía os alunos, que sequer percebiam a importância dos conteúdos. Ao contrário, a consideravam inútil, sem significado, por serem mnemônicas, o que nas palavras de Freire (1982), caracterizava uma educação bancária, na medida em que a memorização se constituía o principal 
objetivo. Além disso, servia à inculcação de um sentimento de patriotismo acrítico, estático, e neutralizante (LEITE, 2002; ROCHA, 1996). A esse respeito Cavalcanti comenta:

\begin{abstract}
A prática desse ensino continua quase inalterada, predominando até agora o ensino tradicional, baseado na memorização de dados isolados, e ainda tendo como critério de avaliação da aprendizagem dos alunos a sua capacidade de reproduzir os conteúdos apresentados, sem questionamentos, sem muito espaço para a reelaboração, para a construção de conhecimentos novos, para a produção da autonomia geográfica. (CAVALCANTI, 2008, p. 24).
\end{abstract}

Tal situação, à luz da contemporaneidade, resultou na busca por novos paradigmas. Desse modo, a Geografia no início do século XXI assinala significativa produção relacionada às questões associadas à educação e consagra uma nova temática, que apesar de ainda não ser uma subárea, vem se desenvolvendo como tal: a Geografia Escolar. Essa vem se constituindo como um campo de investigação que, segundo Lestegás (2012), apresenta-se como um conjunto de gnose claramente estabelecido, legitimado por suas estreitas relações com o saber elaborado pelos especialistas:

O conhecimento científico produz-se nas instâncias que configuram a
comunidade científica e investigadora e, como tal, está submetido a
requisitos de cientificidade que lhe asseguram esse reconhecimento.
Portanto, alimenta-se dos problemas que a ciência deve tentar responder
satisfatoriamente, o que o converte em um saber que se constitui à medida
que se vai produzindo. Em contraposição, o conhecimento escolar organiza-
se em torno de resultados, porquanto se transmite o que já se pesquisou, o
que se conhece com segurança, deixando à margem aquilo sobre o que a
ciência duvida ou que mantém ainda sob interrogação. (LESTEGÁS, 2012,
p. 14).

Nesse contexto de transição paradigmática, onde se sobressai a dimensão do ensino, proposições tem sido feitas no sentido de (re)construir orientações, conforme explicita Cavalcanti:

Toda essa produção buscou analisar o ensino de Geografia e propor orientações com vistas a alterações em sua prática, orientações explicitadas nos livros didáticos mais recentes, em livros acadêmicos e em diversas diretrizes curriculares, destacando-se, aqui, pela sua abrangência, os Parâmetros Curriculares Nacionais (PCNs 1998). (CAVALCANTI, 2008, p. 24).

A estrutura da Geografia Escolar é realizada e praticada, em última instância, pelo professor dessa disciplina. Tal aplicação prática obedece aos PCN e Diretrizes Curriculares Nacionais, que servem como norteadores ao exercício da docência. Importante ressaltar que essa prática se insere no contexto da vertente pedagógica Histórico-crítica, pois, de acordo com Saviani, 
Parte-se da crítica à pedagogia tradicional (pedagogia bancária) caracterizada pela passividade, transmissão de conteúdos, memorização, verbalismo etc. e advoga-se uma pedagogia ativa, centrada na iniciativa dos alunos, no diálogo (relação dialógica), na troca de conhecimentos. (SAVIANI, 1983, p. 68).

Diante dessas considerações, compreende-se que a superação das concepções tradicionais do ensino em geral, e da Geografia, em particular, passa por um trabalho pedagógico, que possibilite aos discentes desenvolver um olhar crítico sobre a realidade social em que vivem. Nesse sentido, tal trabalho deve proporcionar condições de vivência e reflexão sobre a própria vida e a atuação cidadã, função essa que imputa à escola o papel de viabilizar uma educação transformadora. Nesse contexto, a Geografia apresenta-se como um componente curricular que contribui para a formação de indivíduos críticos e participativos na sociedade, o que pode ser associado à formação da cidadania.

Nesse contexto, e com tal responsabilidade social, a atuação do professor é diferenciada, conforme atesta Cavalcanti:

\begin{abstract}
O trabalho docente orientado para o desenvolvimento teórico dos alunos se desenvolve buscando estabelecer, com a intervenção deliberada do professor, a relação do aluno com o mundo objetivo. Nessa relação, o aluno desenvolve sua capacidade mental, sobretudo a de formar conceitos, para lidar com o mundo. Ajudar a formar conceitos é, portanto, papel central do professor. (CAVALCANTI, 2012, p. 158).
\end{abstract}

Tal orientação, no âmbito do ensino de Geografia na escola, expressa uma orientação pautada em pressupostos de Vygotsky, que foram incorporados por Cavalcanti (2012) em sua proposição metodológica denominada sócioconstrutivismo, a qual, de acordo com Boiko e Zamberlan (2001, p. 51), caracteriza-se por "efeito da interação social, da linguagem e da cultura na origem e na evolução do psiquismo humano".

$\mathrm{Na}$ discussão em defesa de sua proposição, Cavalcanti (2006) aponta ações didáticas que propiciam o processo ensino-aprendizagem, tais como: "considerar a vivência dos alunos como dimensão do conhecimento" (p. 148); "estabelecer situações de interação e cooperação entre os alunos" (p. 151); "contar com a intervenção do professor no processo de aprendizagem dos alunos" (p. 154); "apresentar informações, conceitos e exercitar memorização de dados" (p. 155); "manter relações dialógicas com os alunos e entre os alunos" (p. 158); "promover autorreflexão e sócio reflexão dos alunos" (p. 162); "acompanhar e controlar resultados da construção de conhecimentos pelos alunos" (p. 164). Tais ações didáticas expressam a importância da geografia na formação dos indivíduos, principalmente 
quando se pretende formar pessoas que saibam ler o mundo, de modo crítico, a ponto de desenvolverem condutas coerentes diante dos desafios impostos pela contemporaneidade.

Deve-se ressaltar, ainda, que a educação é fator primordial na formação do sujeito, pois contribui para sua não alienação. A Educação serve para libertar. Nessa perspectiva, Freire (1982) assinala que a verificação do conteúdo é concebida por meio de "um esforço comum da consciência da realidade e, autoconsciência, que a inscreve como ponto de partida do processo educativo, ou da ação cultural de caráter libertador" (FREIRE, 1982, p.117). Libâneo (1994) dialoga com essa concepção freireana quando afirma que é função da Educação "[...] prover os indivíduos dos conhecimentos e experiências culturais que os tornam aptos a atuar no meio social e a transformá-lo em função de necessidades econômicas, sociais e políticas da coletividade" (LIBÂNEO, 1994, p.17).

A escola inserida em uma sociedade globalizada, em constante modificação, deve preparar o sujeito para as mudanças políticas, culturais e sociais, conforme propõe Ferreira (2001): "Sem dúvida, um dos mais importantes objetivos da educação é contribuir para o desenvolvimento da autonomia, ajudar os alunos a se tornarem moral e intelectualmente livres, aptos a pensar e agir de forma independente" (FERREIRA, 2001, p. 22).

Na mesma linha de raciocínio, Cavalcanti (2011), em análise sobre a escola e o ensino de Geografia na sociedade contemporânea, afirma que o condicionante para escola superar os obstáculos impostos pela estrutura legal e institucional vigente, é o compartilhamento de práticas de gestão e de aprendizagem para além da sala de aula:

[...] a escola, e não só os professores em sala de aula, deve ser responsável pelo envolvimento dos seus alunos em seu próprio processo de aprendizagem, de formação intelectual, social e afetiva. A escola tem um papel importante como espaço do debate dos problemas educacionais vivenciados no país e na própria comunidade onde se situa, e deve também ser responsável pelo exercício da cidadania crítica, criativa e participativa. Para isso, deve se pautar por uma relação respeitosa entre as pessoas, por uma abertura ao diálogo, ao debate, à diversidade, à criatividade das pessoas que ali vivem. (CAVALCANTI, 2011, p. 82-83).

Nesse contexto a Geografia desempenha um papel fundamental na construção da autonomia dos educandos, conforme expressam os objetivos gerais da disciplina nos PCN:

Conhecer o mundo atual em sua diversidade, favorecendo a compreensão, de como as paisagens, os lugares e os territórios se constroem; Identificar e avaliar as ações dos homens em sociedade e suas consequências em diferentes espaços e tempos, de modo que construa referenciais que possibilitem uma participação propositiva e reativa nas questões 
socioambientais locais; Conhecer o funcionamento da natureza em suas múltiplas relações, de modo que compreenda o papel das sociedades na construção do território, da paisagem e do lugar; Compreender a espacialidade e temporalidade dos fenômenos geográficos estudados em suas dinâmicas e interações; Compreender que as melhorias nas condições de vida, os direitos políticos, os avanços tecnológicos e as transformações socioculturais são conquistas ainda não usufruídas por todos os seres humanos e, dentro de suas possibilidades, empenhar-se em democratizálas; Conhecer e saber utilizar procedimentos de pesquisa da Geografia para compreender a paisagem, o território e o lugar, seus processos de construção, identificando suas relações, problemas e contradições. (PCN DE GEOGRAFIA, 1998, 35).

Desse modo, espera-se que ao final do ensino fundamental obtenham conhecimentos referentes a conceitos, procedimentos, e atitudes ligados à cidadania. Assim, compreende-se que o conhecimento adquirido na escola por meio de disciplinas, conduza o sujeito ao exercício de seus direitos à cidadania, como pondera Cavalcanti:

[...] cidadão é aquele que exerce seu direito a ter direitos, ativa e democraticamente, o que significa exercer seu direito de, inclusive, criar novos direitos e ampliar outros. É no exercício pleno da cidadania que se torna possível, então, transformar direitos formais em direitos reais". (CAVALCANTI, 2008, p. 85).

Para o alcance do objetivo de contribuir para a formação da cidadania por meio do ensino de Geografia, além de implementar ações didáticas numa perspectiva socioconstrutivista, é preciso, ainda, verificar os caminhos percorridos pelos professores dessa disciplina. Com isso, acredita-se, que será possível entender o desenvolvimento das práticas docentes, desde suas concepções pessoais às suas experiências com o ensinar e aprender Geografia e a execução das recomendações contidas nos PCN, DCN, PPP e Planos de Ensino.

A ciência geográfica deve trabalhar conteúdos que possibilitem aos educandos se perceberem participantes do espaço em que vivem no sentido de identificarem que os fenômenos ai existentes, são resultados da vida e do trabalho de toda uma coletividade. Assim, espera-se, que os educandos possam compreender o mundo que os cerca, para exercitarem sua cidadania plena. Entretanto, para que essa compreensão ocorra, torna-se necessário considerar o lugar de vivência, como o parâmetro de realidade, prisma pelo qual será constituída a leitura do mundo. Desse modo, o lugar possibilitará uma compreensão do próprio processo de produção do espaço, conforme atesta Tuan (1983, p. 6): "o espaço transforma-se em lugar à medida que conhecemos melhor e o dotamos de valor". 
Tal perspectiva é ratificada por Ferreira (2000, p. 68) que afirma: "ao dotarmos de valor o lugar, ele será o centro de significações insubstituíveis para a fundação de nossa identidade como indivíduos e como membros de uma comunidade". Assim, o estudo do lugar constitui-se uma alternativa metodológica ao ensino de Geografia, que possibilita uma abordagem das questões sociais, econômicas, culturais e ambientais, a partir do próprio indivíduo e ou comunidade, conforme atesta Callai (2000, p. 84): "Estudar e compreender o lugar em Geografia significa entender o que acontece no espaço onde se vive para além de suas condições naturais ou humanas".

Vários são os autores que consideram a perspectiva do Lugar. Nesse sentido, podese apontar Tuan (1983), que considera os lugares como núcleos de valor, que podem ser totalmente apreendidos através de uma experiência total englobando relações íntimas próprias do residente. Para Straforini (2001) a consideração da categoria lugar "precisa ser entendida como ponto de encontro de espaços locais e globais", assim, entendido pelo autor como "totalidade-mundo". Já para Francischett (2002), a noção de lugar encontra-se subentendida na ideia de que o professor deve desenvolver um trabalho que "respeite a realidade vivida do aluno", contribuindo, assim, para a relação entre o conhecimento adquirido em seu espaço de vivência e o conteúdo estudado. Assim, o conceito de lugar aproxima-se da noção de espaço vivido.

De acordo com Gomes (1996, p. 319) o espaço vivido é "compreendido como um espaço de vida, construído e representado pelos atores sociais que circulam neste espaço". Portanto é tudo aquilo que se desenvolve no espaço geográfico, desde as relações interpessoais, até mesmo a dimensão de uma cidade, vivenciadas por um sujeito, numa dada coletividade. A esse respeito Relph (1979) busca compreender os seres humanos mediante as suas dificuldades, as relações interpessoais, ligando ao mundo da intersubjetividade. Assim, o mundo vivido social, é visto e experienciado, não como uma soma de objetos, mas como um sistema de relações entre o homem e sua vizinhança, como foco de seus interesses, o que Ihe confere identidade. Então, para Relph (1980, p. 61), a identidade do lugar é formada de três componentes inter-relacionados: características físicas, atividades observáveis e significados. Assim, o lugar pressupõe afetividade, pertencimento e topofilia. Essa é considerada uma percepção mais ampla, que inclui todos os laços afetivos dos seres humanos com seu meio ambiente material (TUAN, 1980, p. 107).

Diante dessas considerações, pode-se afirmar que a leitura e compreensão do mundo pelo aluno, a partir de seu lugar, começa com a construção/consolidação do 
sentimento de afetividade, identidade e pertencimento do aluno, pelo seu lugar. Considerando-se que a noção de pertencimento é um importante fator de desenvolvimento da cidadania, pode-se afirmar que o ensino de Geografia tem a possibilidade efetiva de proporcionar a constituição desse sentimento aos alunos, no sentido de thes mostrar que integram um coletivo, compõem e produzem o espaço e, por conseguinte, assumem responsabilidades diante desses, o que conforma a dimensão de cidadania. Tal ideia é corroborada por Callai (2005, p. 247) que afirma: "A Geografia é uma ciência social, que ao ser estudada, tem de considerar o aluno e a sociedade em que vive. Não pode ser uma coisa alheia, distante, desligada da realidade".

Na mesma perspectiva, os Parâmetros Curriculares Nacionais de Geografia do Ensino Médio retomam o conceito de Lugar e o colocam na posição de imputar significados aos conteúdos:

\begin{abstract}
O conceito de lugar guarda uma dimensão prático-sensível que a análise vai aos poucos revelando. Lugar é a porção do espaço apropriável para a vida, que é vivido, reconhecido e cria identidade. Ele possui densidade técnica, comunicacional, informacional e normativa. Guarda em si o movimento da vida, enquanto dimensão do tempo passado e presente. É nele que se dá a cidadania, o quadro das mediações se torna claro e a relação sujeito-objeto direta. É no lugar que ocorrem as relações de consenso e conflito, dominação e resistência. É a base da reprodução da vida, da tríade cidadão-identidade-lugar, da reflexão sobre o cotidiano, onde o banal e o familiar revelam as transformações do mundo e servem de referência para identificá-las e explicá-las. (PCNEM, Ciências Humanas e suas Tecnologias, 2000, p.33).
\end{abstract}

Nesse contexto, Carlos (2007, p.18) chama a atenção para a tríade cidadaniaidentidade-lugar e aponta "a necessidade de considerar o corpo, pois é dele que o homem habita e se apropria do espaço". Então, pode-se concluir, que é a partir do corpo e das interações humanas entre cotidiano e o familiar, que se constituem os lugares. O lugar possui uma relação de sentimento do ser: trata-se de uma conjuntura de desenvolvimento de atividades, que proporciona uma exteriorização de sentidos e que liga o homem ao mundo por meio de um elo afetivo com o meio em que vive. O lugar é, então, o espaço vivido do indivíduo no contexto de uma coletividade.

Assim, o espaço vivido constitui-se o espaço das relações sociais do nosso dia a dia, por exemplo: a nossa casa, bairro, escola, ou seja, é o espaço das possíveis representações e também é o cenário de ações e interações sociais. Nesse sentido, Lefèbvre (1980) acrescenta que a simbolização do espaço se estabelece sobre o que é vivido, percebido e concebido, por meio de um processo dialético ininterrupto, no qual as 
representações dos espaços constituem-se "fatos de palavras e de prática social" Lefèbvre (1980, p. 94) e se caracterizam por serem de natureza social, psíquica e política ao mesmo tempo.

Nessa linha de raciocínio Lefèbvre (1980) pondera que o espaço vivido é, também, dubiedade das relações sociais, pois as pequenas representações articulam-se com o saber, os sonhos, as lembranças e as ficções de cada um. Por isso, é no espaço que se encontra a chave para a compreensão da produção e reprodução do homem em sociedade, o que demonstra o poder que a representação desse possui, para transformar e substituir a realidade vivida e percebida. Assim, o espaço vivido é, sem dúvida, um meio de engajamento do homem na sua própria ação transformadora.

As considerações desses autores, que são complementares uns aos outros, nos permite perceber a relação entre os conceitos de lugar e espaço vivido. Nesse sentido, para o presente trabalho, considerar-se-ão tais conceitos como sinônimos. Além disso, é importante explicitar que os argumentos que construiu esta investigação, priorizou o entendimento de lugar estabelecido por Callai (2005).

Diante do exposto, pretende-se entender o desenvolvimento das práticas docentes, a partir das concepções pessoais dos professores, suas experiências com o ensinar e aprender geografia e sua prática em relação às recomendações contidas nos PCN, DCN, PPP e planos de ensino, cujas explicitações sobre seus propósitos apresentam-se a seguir.

\section{Os fundamentos legais}

Parte da premissa de que os dispositivos legais norteiam e orientam as práticas pedagógicas dos professores no Brasil. Nesse sentido, aqui serão estudados e explicitados os fundamentos legais da ação do professor de Geografia, no tocante à formação da cidadania e à consideração do conceito de lugar.

Assim, seguem abaixo, sínteses dos documentos selecionados para esta pesquisa, a saber: PCN de Geografia, CMEB-DF, PPP e PE.

\subsection{PCN de Geografia}

Os PCN's foram criados no final década de 1980 e apresentados à sociedade por volta de 1994. Este documento vinha, segundo o MEC, atender à necessidade da renovação 
e mudanças nos currículos escolares brasileiros, que estavam defasados em relação às novas necessidades educacionais do mundo global. Também foram modificadas as nomenclaturas de $1^{\circ}$ e $2^{\circ}$ Graus para Ensino Fundamental e Médio.

Nessa perspectiva,

O MEC adotou uma política educacional centralizadora. Os Estados da Federação já não poderiam estabelecer os respectivos currículos, como o tinham feito até então. Com essa política, a Secretaria de Ensino Fundamental do MEC elaborou um documento curricular de referência para todo o Brasil, visando de acordo com esse órgão, a uma educação de qualidade que assegurasse às crianças e aos jovens brasileiros, mesmo nos locais de infraestrutura restrita e condições sócio econômicas desfavoráveis, o acesso aos conhecimentos socialmente elaborados e reconhecidos como necessários ao exercícios da cidadania. Desse modo, garantiria o respeito a diversidade cultural do país mediante a possibilidade de adaptações que integrasse as diferentes dimensões da prática educacional. (PONTUSCHKA, PAGANELLI E CACETE, 2009, p.74).

Assim, compreende-se que os dispositivos legais norteiam as práticas pedagógicas dos professores e aqui serão brevemente explicitados os fundamentos legais à ação do professor de geografia, no tocante à formação da cidadania e à consideração do conceito de lugar.

O contexto educacional, em geral, e o ensino de Geografia, em particular, encontram-se num momento onde há significativa reflexão sobre seus propósitos, sua adequação em relação às demandas de formação na contemporaneidade, entre outras questões importantes. Nesse cenário emergem preocupações referentes ao currículo, que tem se concretizado como uma oportunidade de reflexão e discussão sobre as questões afetas à educação, entre aqueles que constituem uma determinada comunidade escolar.

Em relação ao currículo de geografia para a educação básica, há clareza da necessidade de alteração/adaptação de seus conteúdos e propósitos, notadamente a partir da década de 1980. Nesse sentido, há um reconhecimento de práticas vinculadas ao que se denomina Geografia Tradicional - a de base positivista, pautada pela descrição e memorização das características físicas da paisagem - não possibilitavam a compreensão efetiva do processo de produção do espaço, nem tampouco permitiam ao estudante, se perceberem integrantes e partícipes desse processo.

Assim, as discussões de currículo resultaram, também, no equacionamento de questões que se destacam: necessidade de consideração dos contextos político, 
econômico, social, ideológico e cultural no processo de produção do espaço; reconhecimento sobre a necessidade de discussão da geografia numa perspectiva didática, que procura modificar as rotinas e tradições na programação escolar; e, ainda, a busca por respostas relativas ao tipo de aluno que se deseja formar. Nesse sentido, Moraes (2007, p. 27) afirma que o ensino contemporâneo diligencia "uma nova ecologia cognitiva, traduzida na criação de novos ambientes de aprendizagem que privilegiam a circulação de informações, a construção do conhecimento".

Assim, os Parâmetros Curriculares Nacionais buscam fornecer orientações gerais ao currículo, no sentido de superar a perspectiva tradicional, de um lado, e de atender às demandas de formação contemporânea, de outro. Importante ressaltar que não se pretende, aqui, efetuar análise crítica dos PCN's, apenas identificar nesse documento, as ideias e proposições que corroboram com o papel da geografia, de contribuir para a formação da cidadania e a utilização do conceito de lugar. Assim, pretende-se analisar esse documento a partir desse prisma.

E para atender esta nova diligência da educação o Parâmetro Curricular Nacional de Geografia do ensino fundamental está dividido em duas partes principais, onde a primeira parte do documento contém uma contextualização geral da área no ensino fundamental, com explicitação da trajetória da Geografia como ciência e como disciplina escolar, suas tendências atuais e sua importância na formação do cidadão. Apontam-se objetivos, conceitos básicos, procedimentos, atitudes e critérios de avaliação a serem ensinados, para que os alunos se aproximem e compreendam a dinâmica desta área de conhecimento. $\mathrm{Na}$ segunda parte, encontram-se orientações para o trabalho com a área no ensino fundamental, apresentando objetivos, eixos temáticos, conteúdos e critérios de avaliação. Ao final, o documento traz uma série de indicações sobre a organização do trabalho escolar do ponto de vista metodológico e didático. Nas orientações didáticas, são apresentadas sugestões de recursos que podem ser utilizados pelo professor no planejamento de suas aulas e na definição das atividades a serem propostas aos alunos.

As propostas apresentadas no PCN de Geografia do ensino fundamental almejam que, ao final do ensino fundamental, os alunos possam elaborar um conjunto de conhecimentos referentes a conceitos, procedimentos e atitudes relacionados à esta disciplina, que Ihes conceda serem capazes de

Conhecer o mundo atual em sua diversidade, favorecendo a compreensão, de como as paisagens, os lugares e os territórios se constroem; Identificar e 
avaliar as ações dos homens em sociedade e suas consequências em diferentes espaços e tempos, de modo que construa referenciais que possibilitem uma participação propositiva e reativa nas questões socioambientais locais; Conhecer o funcionamento da natureza em suas múltiplas relações, de modo que compreenda o papel das sociedades na construção do território, da paisagem e do lugar; Compreender a espacialidade e temporalidade dos fenômenos geográficos estudados em suas dinâmicas e interações; Compreender que as melhorias nas condições de vida, os direitos políticos, os avanços tecnológicos e as transformações socioculturais são conquistas ainda não usufruídas por todos os seres humanos e, dentro de suas possibilidades, empenhar-se em democratizálas; Conhecer e saber utilizar procedimentos de pesquisa da Geografia para compreender a paisagem, o território e o lugar, seus processos de construção, identificando suas relações, problemas e contradições; Orientálos a compreender a importância das diferentes linguagens na leitura da paisagem, desde as imagens, música e literatura de dados e de documentos de diferentes fontes de informação, de modo que interprete, analise e relacione informações sobre o espaço; Saber utilizar a linguagem gráfica para obter informações e representar a espacialidade dos fenômenos geográficos; Valorizar o patrimônio sociocultural e respeitar a sociodiversidade, reconhecendo-os como direitos dos povos e indivíduos e elementos de fortalecimento da democracia. (PCN DE GEOGRAFIA ENSINO FUNDAMENTAL, 1998, p. 35).

Na dimensão de conhecimentos apresentada pelos PCN's ressalta-se a importância da formação do professor. Marin (1995) afirma que para os professores executarem suas práticas é necessário que adquiram conhecimentos, através de formações inicial e continuada.

Assim, é a formação inicial que possibilita o pensar sobre a realidade e, sob o prisma desta investigação, o saber geográfico. A Geografia ocupa um lugar privilegiado, que possibilita o desenvolvimento da capacidade de observar, analisar, interpretar e pensar criticamente a realidade tendo em vista sua transformação. Ou seja, é fundamental à formação de indivíduos críticos, principalmente para que possam participar na vida social.

Medeiros (2010) afirma que para entendermos a influência das novas tendências que o currículo assume no ensino de Geografia, é preciso observar que o conhecimento desta disciplina precisa ser construído de maneira que reproduza os conhecimentos produzidos culturalmente pela humanidade, redefinidos pelas possibilidades de uma reconstrução continua pelo aluno e pelo professor, no dia-a-dia da sala de aula.

Nessa perspectiva, Cardoso \& Medeiros (2009) esclarecem que ao olharmos para o ensino de Geografia, na possibilidade de entender a semelhança entre a Geografia escolar e o cotidiano dos alunos, encontraremos um desafio que permeia a rotina de tantos professores, que é a constante busca de um aprendizado, que tenha repercussão na vida 
dos discentes. Para isso é necessário que os discentes pensem a realidade na relação com o mundo que os cerca, ou percebam como se dá a integração de cada um deles nas diferentes realidades desse mundo. Assim, o PCN de Geografia aponta que a

[...] Geografia propõe um trabalho pedagógico que visa à ampliação das capacidades dos alunos do ensino fundamental de observar, conhecer, explicar, comparar e representar as características do lugar em que vivem e de diferentes paisagens e espaços geográficos. (PCN DE GEOGRAFIA, 1998, p.15).

Para alcançar a ampliação das capacidades cognitivas dos alunos é importante valorizar a relação professor aluno, principalmente para o desenvolvimento do pensamento crítico sobre o meio em que vive. Nessa perspectiva é possível que ele perceba que a Geografia faz parte do seu cotidiano. Com isso será possível levar discussões para o interior da sala de aula, que permitam entender que sociedade e natureza constituem-se os fundamentos com os quais paisagem, território, lugar e região são construídos.

\subsection{Currículo em Movimento da Educação Básica do Distrito Federal/ CMEB-DF}

O processo de construção do Currículo em Movimento da Secretaria de Educação do Distrito Federal teve início no ano de 2000, mas somente em 2011 foram realizadas as primeiras plenárias com discussões em Grupos de Trabalhos, em parcerias com as Coordenações Regionais de Ensino. No ano de 2012, houve a continuidade das discussões nos GT's e a elaboração de uma minuta organizada por cadernos e, estes, em 2013 foram submetidas às escolas para validação no ano letivo de 2013. No ano de 2013, a SEE-DF e a EAPE organizaram formações nas escolas para que os professores se apropriassem desse documento com fim de auxiliá-los em suas práticas pedagógicas.

O Currículo em Movimento do Distrito Federal/CMEB-DF é o documento norteador da ação didático-pedagógica na rede de ensino do Distrito Federal. Suas orientações propõem que para o ensino/aprendizagem em Geografia torna-se importante criar condições pedagógicas para que o estudante consiga olhar, observar, descrever, registrar e analisar o espaço geográfico, considerando e valorizando o conhecimento prévio do estudante, despertando sua consciência crítica, política e ambiental, possibilitando a construção de sociedades menos desiguais.

O caminho para esse fim se dá por meio da prática cidadã - onde os indivíduos possam exercer seus direitos e deveres, civis, políticos e sociais também, os valores éticos e de respeito às diferenças, a fim de promover aprendizagens contextuais e significativas. 
Nesse sentido, apresentar temas e conteúdos problematizados a partir da prática social, permite interações proveitosas e atendimento ao preceito de organização escolar à serviço da formação e transformação social do educando e nele mesmo.

\begin{abstract}
Os conceitos básicos em Geografia constituem-se como objetivos para o 6으 ano, levando o estudante a compreender seu lugar, interações com seu espaço de vivência, localização e conhecimento do planeta Terra, como também entender e utilizar a cartografia. A partir do $7^{\circ}$ Ano, a proposta de trabalho se dá com a cartografia, no intuito de levar o estudante a localizar continentes, oceanos e mares do mundo, com ênfase em continentes específicos da fase escolar em que se encontra, bem como conhecer o território nacional, suas regiões e compreender aspectos físicos, ambientais, sociais, econômicos e demográficos brasileiros. Para o $8^{\circ}$ e $9^{\circ}$ anos, 0 enfoque remete ao mundo, dividido por continentes, cujo objetivo é conhecer e refletir sobre aspectos físicos, ambientais, sociais e econômicos dos mesmos. (CURRÍCULO EM MOVIMENTO DA EDUCAÇÃO BÁSICA EDUCAÇÃO FUNDAMENTAL ANOS FINAIS, 2013, p. 126).
\end{abstract}

\title{
2.3 Projeto Político Pedagógico
}

O Projeto Político Pedagógico/PPP é um documento que facilita e organiza as atividades dentro da escola, atuando como mediador de decisões e da condução das ações e da análise dos resultados e impactos. Este ainda se constitui como retrato da memória histórica e registros construídos e que permite aos professores rever e reescrever a sua trajetória de intencionalidades (VEIGA, 2000).

Neste sentido, pode-se entender que o PPP norteia o trabalho da escola por encaminhar ações para o futuro com base na sua realidade atual. De acordo com essa base conceitual, as Diretrizes Pedagógicas de Estado de Educação do Distrito Federal afirmam que:

[...] uma proposta pedagógica deve considerar as questões sociais contemporâneas para que os alunos possam exercer seus direitos e deveres numa participação ativa na vida científica, cultural, social e política da sua comunidade. (DPSEE/DF, 2009-2013, p.14).

Assim, tais Diretrizes propõem que o trabalho pedagógico deva possibilitar que o aluno seja sujeito de sua própria aprendizagem em busca da compreensão do mundo. Nesse sentido, um PPP que contemple a necessidade de compreender a realidade vivida, para estabelecer propostas de estudos e pesquisas, que levem o aluno a compreender e atuar em seu mundo vem de encontro aos objetivos proposto pela disciplina Geografia, uma vez que ambos, PPP e Geografia, caminham de forma interdisciplinar em sua intencionalidade de ensino aprendizagem. 
A lei 9394/96, pelo inciso I do artigo 12, atribui a escola à responsabilidade de elaboração e execução de sua proposta pedagógica. No inciso I do artigo 13 especifica-se que é incumbência dos docentes participar da elaboração da proposta pedagógica do estabelecimento de ensino. Para Veiga (2000), o Projeto Político Pedagógico não é um amontoado de planos de ensino com diversas atividades, mas sim um documento que reflita, analise e questione as limitações da escola na averiguação de alternativas viáveis à efetivação de sua intencionalidade:

O projeto busca um rumo, uma direção. É uma intencional, com um sentido explicito, com um compromisso definido coletivamente. Por isso, todo projeto pedagógico da escola é, também, um projeto político por estar intimamente articulado ao compromisso com a formação do cidadão para um tipo de sociedade. (VEIGA, 2000, p. 13).

\subsection{Plano de Ensino}

O Plano de Ensino/PE prenuncia a intenção e os afazeres da prática docente para um semestre ou um ano letivo, sendo um instrumento que aponta os objetivos específicos, conteúdos e desenvolvimento metodológicos (LIBÂNEO, 1994). Ou seja, o plano de ensino traz suporte ao professor na organização, coordenação e preparação das suas aulas. Assim possibilita alcançar as propostas contidas nos documentos norteadores: PCN, DCN e PPP. Para Turra et al (1995) o plano de ensino possibilita conduzir os alunos ao alcance das propostas e verificar o ritmo do processo educativo. Desse modo, sua elaboração proporciona maior segurança na concentração das metas previstas e com maior qualidade do ensino.

Para Piletti (1990), a elaboração de um plano exige estudo e posicionamento diante de um problema, no intuito de buscar a reflexão e análise para escolher as melhores possibilidades de ações, diante de objetivos que são limitados por certa realidade. A ação de planejar deve estar conectada com a prática. Entretanto, sabe-se que o planejamento de ensino às vezes mostra-se separado da realidade social, sendo percebido e praticado como uma ação involuntária e burocrática do professor, existindo pouca contribuição para o aumento da qualidade de ação pedagógica desenvolvida na escola Lopes (1991).

Hurtado \& Guillermo (1988) classificam o planejamento de ensino como uma conduta que parte da prática do educando, permitindo ao professor alguns pontos como: presumir, racionalizar, ensinar, coordenar, planejar, aperfeiçoar, e adequar os conteúdos às 
necessidades do processo de ensino-aprendizagem, oportunizando torná-lo eficiente, significativo e avaliável. Para Marques (1979), e Martinez \& Lahore (1977), o planejamento permite limitar os resultados, ou seja, prever o que se deseja conquistar em um intervalo de tempo, utilizando-se dos recursos materiais e humanos à custa de procedimentos, estratégias e técnicas. Assim, esse mecanismo permitirá ao professor analisar os objetivos traçados, possibilitando realizar previsões de tempo de execução de tarefa e avaliar a metodologia. Com isso o planejamento deve ser formulado no intuito de atender as imprescindibilidades que os alunos apresentam em sua vida cotidiana.

Baecker et al (1997) acrescentam que, para a elaboração de um planejamento, devese ter como orientação as concepções de sociedade, de homem e de educação, em razão da sociedade ser concebida como um meio onde o homem está agregado e edificador dessa sociedade, influenciando nas regras e normas que são concebidas. Regras que permitem serem repensadas e reformuladas pelos homens para atender a toda coletividade, auxiliando da mesma forma no planejamento.

Desta forma é possível entender que o plano de ensino ou planejamento da educação é um conjunto elaborado e ordenado de intenção de ações, que visam alcançar a efetivação de determinados objetivos, ou seja, é um ato em que se realiza uma antecipação do que se deseja alcançar, podendo ser criado em um determinado tempo, executado e ou reformulado em outro, mas sempre deve estar pautado na realidade de cada região. 


\section{Capítulo II - A Pesquisa Empírica}

O cidadão democrático, ativo, criativo e consciente de seus direitos políticos, sociais, culturais, individuais e territoriais precisa conhecer a cidade, compreendê-la com profundidade, decifrar seus símbolos, desenvolver um sentido ético e estético sobre ela, para que possa lutar e conquistar seus direitos cívicos e sociais e cumprir com seus deveres, individuais e coletivamente. Como afirma Santos (1987, p. 14), a cidadania se aprende. Sem essa aprendizagem, a torna-se impalpável. (CAVALCANTI, 2010).

\section{Metodologia}

A compreensão dos processos relativos ao ensino de Geografia, no sentido de identificar se o papel dessa área do conhecimento vem sendo cumprido na escolarização, desencadeia a necessidade de buscar os significados conferidos pelos professores a sua prática de ensino. Para o alcance dessa intenção, então, a abordagem qualitativa é a mais adequada. De acordo com Bauer \& Gaskell (2002, p. 23), "[...] a pesquisa qualitativa evita números, lida com interpretações das realidades sociais. O protótipo mais conhecido é, provavelmente, a entrevista em profundidade".

Haguette (1997), discute a importância da entrevista nas pesquisas sociais e aponta que é nesse tipo de coleta de dados que os pesquisadores procuram conseguir elementos objetivos e subjetivos. Ao analisar as contribuições de Haguette (1997) e Bauer \& Gaskell (2002), percebe-se que ambos compartilham das mesmas convicções a respeito da entrevista como metodologia de coleta de dados. Bauer \& Gaskell (2002) afirmam que esta é mais apropriada, possibilitando atingir os objetivos com mais profundidade:

Toda pesquisa com entrevistas é um processo social, uma interação ou um empreendimento cooperativo, em que as palavras são o meio principal de troca. Não é apenas um processo de informação de mão única passando de um (o entrevistado) para outro (o entrevistador). Ao contrario, ela é uma interação, uma troca de ideias e de significados, em que várias realidades e percepções são exploradas e desenvolvidas, Com respeito a isso, tanto o(s) entrevistado(s) como o entrevistador estão, de maneiras diferentes, envolvidos na produção do conhecimento. (BAUER \& GASKELL, 2002, p. 73).

Para Andrade a entrevista permite maior liberdade ao entrevistado e ao entrevistador: "Ocorre que a maior liberdade exige do pesquisador mais segurança, melhor preparo, mais presença de espírito, enfim, o resultado da entrevista vai depender, muito mais, da competência do entrevistador". (ANDRADE, 2010, p.137). 
Assim, a presente investigação busca identificar aqueles significados a partir de análise documental - PCN, CM/EB-DF, PPP CEF-28 -, questionários e entrevistas semi estruturadas com os professores participantes desta pesquisa. Nesse sentido, esta pesquisa constitui-se um estudo de caso, pois procura compreender a prática docente de uma disciplina em uma escola.

\begin{abstract}
O estudo de caso é o estudo de um caso, seja ele simples e específico, como o de uma professora competente de uma escola pública, ou complexo e abstrato, como o das classes de alfabetização (CA) ou o do ensino noturno. O caso é sempre bem delimitado, devendo ter seus contornos claramente definidos no desenrolar do estudo. O caso pode ser similar a outros, mas é ao mesmo tempo distinto, pois tem um interesse próprio, singular. Segundo Goode e Hatt (1968), o caso se destaca por se constituir numa unidade dentro de um sistema mais amplo. O interesse, portanto, incide naquilo que ele tem de único, de particular, mesmo que posteriormente venham a ficar evidentes certas semelhanças com outros casos ou situações. Quando queremos estudar algo singular, que tenha um valor em si mesmo, devemos escolher o estudo de caso. (LUDKE, 1986, p. 17).
\end{abstract}

Para Yin (2005), em concordância com Ludke (1986) esta metodologia é adequada à investigação de um acontecimento contemporâneo, dentro de seu contexto real, onde os limites entre o fenômeno e o contexto não são claramente percebidos. Nesse sentido, Gil afirma que:

Os propósitos do estudo de caso não são os de proporcionar o conhecimento preciso das características de uma população, mas sim o de proporcionar uma visão global do problema ou de identificação possíveis fatores que o influenciam ou são influenciados. (GIL, 2002, p.55).

Nesse contexto, a análise documental, a aplicação de questionários e a realização de entrevistas semiestruturadas serão os meios pelos quais as informações serão construídas.

Em relação à análise documental serão utilizados os Parâmetros Curriculares Nacionais de Geografia para o ensino fundamental II, Currículo em Movimento da Educação Básica do Distrito Federal na área do conhecimento de Geografia, Projeto Político Pedagógico do CEF-28 de Ceilândia e o Plano de Ensino dos professores de Geografia.

O questionário como método de coleta de dados poderá ser definido como técnica de investigação social, composta por questões que são submetidas a pessoas, com o propósito de obter informações sobre conhecimentos, crenças, sentimentos, valores, interesses, expectativas, aspirações, temores, comportamento presente ou passado (GIL, 2002). 
O questionário é um instrumento de coleta de dados composto por uma sequência de perguntas, e estas podem ser classificadas em perguntas abertas, fechadas ou mistas. De acordo com Marconi e Lakatos (2010, p. 184) os questionários "(...) devem ser respondidas por escrito e sem a presença do entrevistador”. Em suas próprias palavras:

\begin{abstract}
A elaboração de um questionário requer a observância de normas precisas, a fim de aumentar sua eficácia e validade. Em sua organização, devem-se levar em conta os tipos, a ardem, os grupos de perguntas, a formulação das mesmas e também "tudo aquilo que se sabe sobre percepção, estereótipos, mecanismos de defesa, liderança etc." [...] O processo de elaboração é longo e complexo: exige cuidado na seleção das questões, levando em consideração a sua importância, isto é, se oferece condições para obtenção de informações válidas. Os temas escolhidos devem estar de acordo com os objetivos geral e específicos. (MARCONI e LAKATOS, 2010, p. 185).
\end{abstract}

Desse modo, nesta pesquisa, esse instrumento foi utilizado para servir como elemento de comparação às respostas dos professores, na medida em que também passaram por entrevistas semiestruturadas.

As entrevistas semiestruturadas, de acordo com Ludke (1986), representam um dos instrumentos básicos para a coleta de dados e é vantajosa, notadamente em relação a outras técnicas, por permitir um apanhado imediato e fluente da informação desejada:

\begin{abstract}
O tipo de entrevista mais adequado para o trabalho de pesquisa que se faz atualmente em educação aproxima-se mais dos esquemas mais livres, menos estruturados. As informações que se quer obter, e os informantes que se quer constatar, em geral professores, diretores, orientadores, alunos e pais são mais convenientemente abordáveis através de um instrumento mais flexível. (LUDKE, 1986, p. 34).
\end{abstract}

\title{
2. Método
}

\subsection{O Contexto de Construção das Informações Empíricas}

A escolha do local da pesquisa foi decorrente da vivência do pesquisador, que tem seu exercício profissional na escola alvo de investigação, situada em área de vulnerabilidade social e com população proveniente de uma das maiores favelas brasileiras: o setor Sol Nascente, na Região Administrativa de Ceilândia/DF. Nesse contexto, o exercício do magistério permitiu a percepção que os alunos que estudam no CEF-28 de Ceilândia demonstram desconhecimento das problemáticas que envolvem sua comunidade e sequer se percebem como integrantes dessa e com potencial de se constituírem agentes de transformação social. Tal percepção é respaldada, de um lado, pelos resultados obtidos 
na disciplina Geografia, que foi aquela que mais reprovou os alunos no ano de 2013, e das constatações obtidas pelo próprio pesquisador em sua prática docente.

Tais impressões se constituíram motivo de reflexão, na medida em que o ensino de Geografia deveria promover, ao menos, uma leitura de mundo, da realidade vivida, por parte dos alunos (CALLAI, 2005). Em tese, esses deveriam compreender a dinâmica social onde estão inseridos, como princípio fundamental às possíveis ações, orientadas à melhoria das condições de vida a partir, por exemplo, da própria escola. Assim, surgiram questionamentos em relação ao ensino de Geografia, no que se refere ao cumprimento de seu papel: promover a compreensão de problemas de ordem global, a partir de uma escala local, contribuir para o desenvolvimento do pensamento crítico e possibilitar a construção da noção de cidadania.

Desse modo, esta pesquisa se constrói a partir do entendimento do lugar onde se insere a escola, no sentido de identificar suas principais características e suas possíveis relações com os objetivos de aprendizagem de Geografia. Em consequência, torna-se necessário desvelar, não somente tais características, como também o contexto onde se constitui essa dinâmica social.

\subsection{1 - O lugar da pesquisa: o Condomínio Sol Nascente, na Região Administrativa da Ceilândia/DF}

A construção/inauguração/consolidação de Brasília constituiu-se um importante fator de integração regional, na medida em que promoveu articulação do território nacional a partir da região Centro-Oeste. Em consequência, os fluxos migratórios, antes direcionados majoritariamente ao sudeste brasileiro, reorientaram-se à capital federal, conforme atesta Morelli:

\footnotetext{
Segundo levantamento feito em 1970, existiam quase 15.000 barracos nesta região, com uma população superior 80.000 pessoas. Este contingente representava $15 \%$ da população existente em Brasília. 0 processo de urbanização do DF, assim como no resto do país, passou, então, a ser marcado por intensa favelização. (MORELLI, 2002, p. 26).
}

Assim, Brasília atraiu expressivo contingente populacional, superando as expectativas em termos populacionais. Destinada à ocupação exclusiva do funcionalismo público federal e distrital, a história do Distrito Federal a partir de Brasília, efetiva-se pela segregação espacial, na medida em que aqueles que não tinham relação direta com o funcionalismo público, não tinham direito à moradia nos setores residenciais de Brasília 
(PAVIANI, 1996). Desse modo, ao redor dessa cidade foram aparecendo outras, denominadas satélites, para abrigar os demais habitantes, principalmente os migrantes, assinalando que o processo de segregação espacial se estabelece desde os primórdios de Brasília. Nesse contexto a gestão do território do DF sempre exigiu ações de contenção da migração de um lado, e de adoção de medidas para resolver o frequente processo de invasões de áreas públicas, também por meio de favelas, de outro. Nesse sentido, Ferreira \& Moreira afirmam que:

Havia uma preocupação com o crescimento demográfico em Brasília, onde poderia ocasionar a perda da identidade política-administrativa e cultural da nova capital, deste modo foram criadas três escalas de atuação sobre a área de influencia de Brasília: área de controle, área de contenção e escala regional. (FERREIRA \& MOREIRA, 2012, p.6).

Nesse panorama, de área de controle e contenção, se estabelece a campanha de erradicação de invasões/CEI, que dá origem a cidade de Ceilândia.

Segundo Silva (1983) a cidade de Ceilândia-DF surgiu em 1971, a partir da Campanha de Erradicação de Invasões realizada pelo então governador Hélio Prates da Silveira, com objetivo de resolver o problema das invasões que proliferaram em Brasília, desde os anos 1960. Essas, com toda sua extensa e complexa cadeia de problemas, não poderiam estar associadas à Capital Federal brasileira, centro do poder nacional. Em consequência o governo do Distrito Federal desenvolveu um plano de extensão territorial, onde se institui a criação da Ceilândia, para receber a população de baixa renda, que vivia em Brasília.

Assim, a cidade de Ceilândia nasce com o estigma de ser habitada por pessoas de baixa renda e distante da capital. De acordo com a pesquisa Distrital por Amostra de Domicílios/PDAD, realizada pela Companhia de Planejamento do Distrito Federal/CODEPLAN, de 2010/2011 a cidade possui 398.374 habitantes. Porém, em virtude de um processo de inchaço urbano, com a criação de novos setores habitacionais - Sol Nascente e Por do Sol - estima-se que a Ceilândia tenha cerca de 442.865 habitantes (CODEPLAN, 2013). 


\section{Imagem 1 - Ceilândia e Sol Nascente}

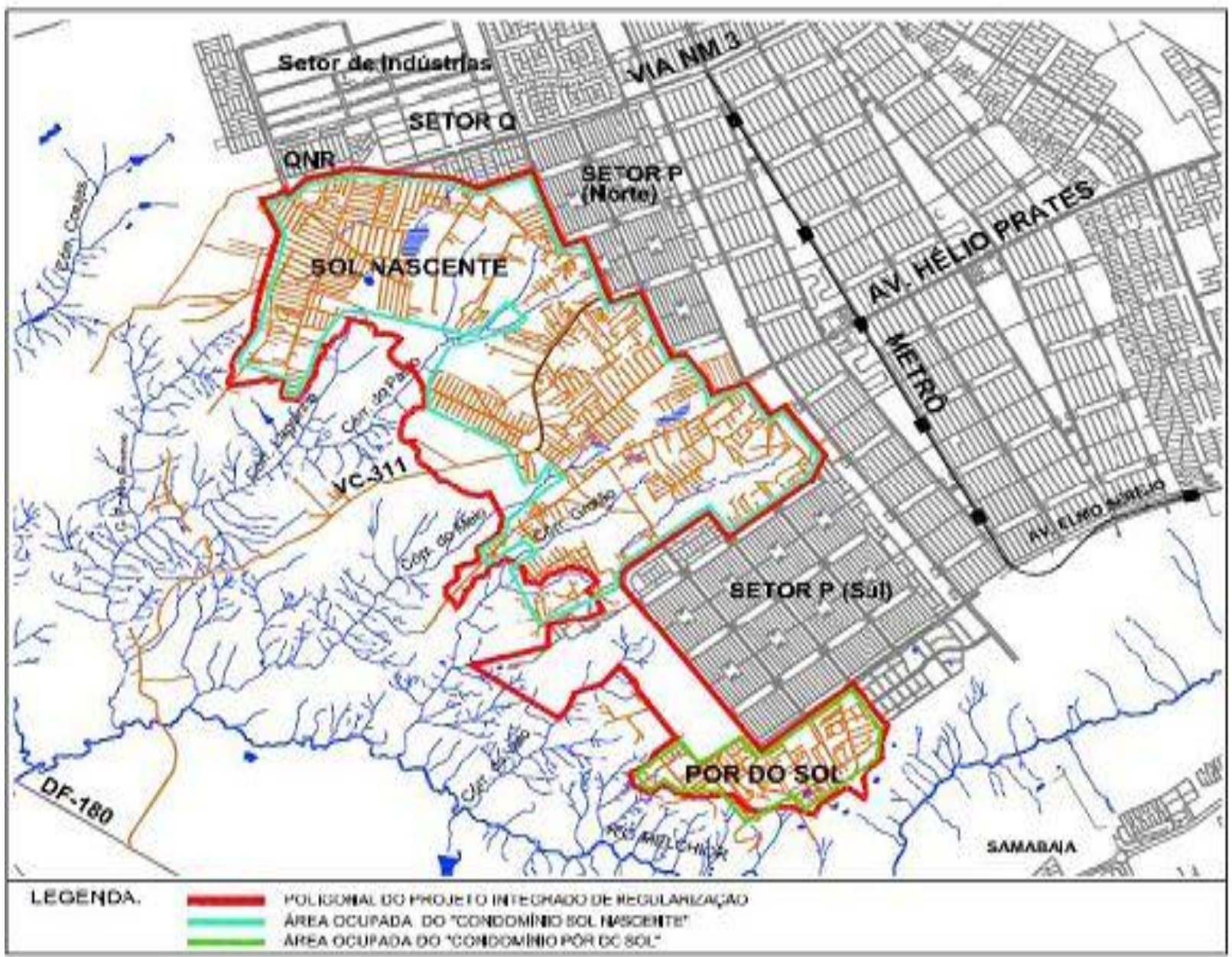

Fonte: CODEPLAN (2013)

Interessante observar que a política habitacional no DF apresentou basicamente duas faces, onde:

A primeira, de controle populacional, reduz a oferta de moradias, acreditando que isso reduziria o fluxo migratório para a cidade, fator que não ocorreu, sendo muito comum nos governos militares, que viam a necessidade de manter o perfil estratégico da cidade longe de grandes contingentes populacionais. E a segunda, com grande oferta de moradias nos períodos próximos às eleições, fundando assim uma política clientelista, realizada em grande parte durante os vários governos Roriz. (SANTOS, 2010, p. 31).

Por oportuno cumpre esclarecer que o governador Joaquim Roriz permaneceu no poder por treze anos intercalados - 1988/1990, 1991/1995, 1999/2006- período no qual implantou vários núcleos urbanos no entorno da Capital Federal para atender ao crescimento populacional do DF, os quais, futuramente, viriam a se constituir novas Regiões 
Administrativas, a saber: Samambaia, Santa Maria, Riacho Fundo, Recanto das Emas, São Sebastião. Importante ressaltar que o contingente populacional do DF, antes do período Roriz, era de aproximadamente 1.176.935 habitantes (IBGE, 1980), passando para 2.606.885 (IBGE, 2009) habitantes após suas gestões.

Esse é o contexto que assinala o surgimento do setor Sol Nascente, na Ceilândia, criado no terceiro mandato do governador Joaquim Roriz, em área que pertencia à Companhia Imobiliária de Brasília/Terracap. Tal localidade tem sua origem em 1984, quando a Fundação Zoobotânica do Distrito Federal, instituição com personalidade jurídica e administradora das terras rurais do DF em conjunto com a Companhia Imobiliária de Brasília/Terracap arrendaram parte destes terrenos, para a realização de práticas agropecuárias que desenvolviam no local. Tal situação fez com o local ficasse conhecido como Parque da Vaquejada.

Posteriormente, em 1998, começam a surgir os primeiros aglomerados subnormais ao lado do bairro QNQ de Ceilândia, e com rápido avanço em direção das chácaras arrendadas. Os arrendatários dividiram em terrenos menores, sendo vendidos com valores bem abaixo de preços de mercado e repassados com documento de Cessão de Direitos, qualificando a localidade como ocupação urbana desordenada, onde se destacam as práticas de invasão e grilagem. Esses processos, seguidos de aquisições de terras na localidade, juntamente com a contínua e crescente migração de pessoas, com mão de obra desqualificada para o atual mercado produtivo, foi aos poucos, porém, de uma forma agressiva, transformando o Setor Habitacional Sol Nascente na maior favela do Brasil, segundo dados da CODEPLAN (2013). Como tal, abriga população carente, notadamente de equipamentos públicos, conforme atesta o Relatório de Estudo de Impacto AmbientalEIA, realizado pela Progea Engenharia e Estudos Ambientais Ltda, encomendada pela TERRACAP em 2009. De acordo com esse documento, para que a população disponha de um mínimo de qualidade de vida, seriam necessários equipamentos públicos comunitários/EPC's, conforme atesta o quadro que se segue: 


\section{Quadro 1- Números de EPC's necessários para o Sol Nascente}

\begin{tabular}{|l|c|}
\hline Delegacia Circunscricional & 1 \\
\hline Posto Policial & 4 \\
\hline Companhia Regional de Incêndio & 1 \\
\hline Centro de Saúde & 2 \\
\hline Posto de Saúde Família & 11 \\
\hline Escola de Ensino Infantil & 54 \\
\hline Escola de Ensino Fundamental & 17 \\
\hline Escola de Ensino Médio & 3 \\
\hline Vila Olímpica & 2 \\
\hline Equipamento Cultura Local & 3 \\
\hline Equipamento Cultura Regional & 1 \\
\hline Parque de Bairro & 4 \\
\hline
\end{tabular}

Fonte: TERRACAP- EIA ${ }^{1}$ Ceilândia-DF (Organização: Silva, A. D).

A ausência de equipamentos sociais e infraestrutura para saneamento básico desencadeiam problemas de várias ordens, que afetam o cotidiano das pessoas, como por exemplo, ruas alagadas na época das chuvas, falta de luz, violência, entre outras. Essas ocorrências, por sua vez, ao afetar o cotidiano dos alunos podem repercutir nas questões relativas a escola e à escolarização. Nesse sentido, torna-se necessário apresentar o Centro de Ensino Fundamental 28 de Ceilândia, lugar desta investigação.

\subsection{2 - O Centro de Ensino Fundamental 28 de Ceilândia}

O Centro de Ensino Fundamental 28 de Ceilândia está localizado na Quadra Norte P - QNP 21 Área especial na cidade de Ceilândia.

\footnotetext{
${ }^{1}$ Estudos de Impactos Ambientais-EIA. Avaliação das ocupações irregulares nas bordas da cidade de Ceilândia-DF, volume I, TOMO III (parte 7), 2009, p. 717.
} 


\section{Mapa 1 - Localização do CEF-28 na Ceilândia}

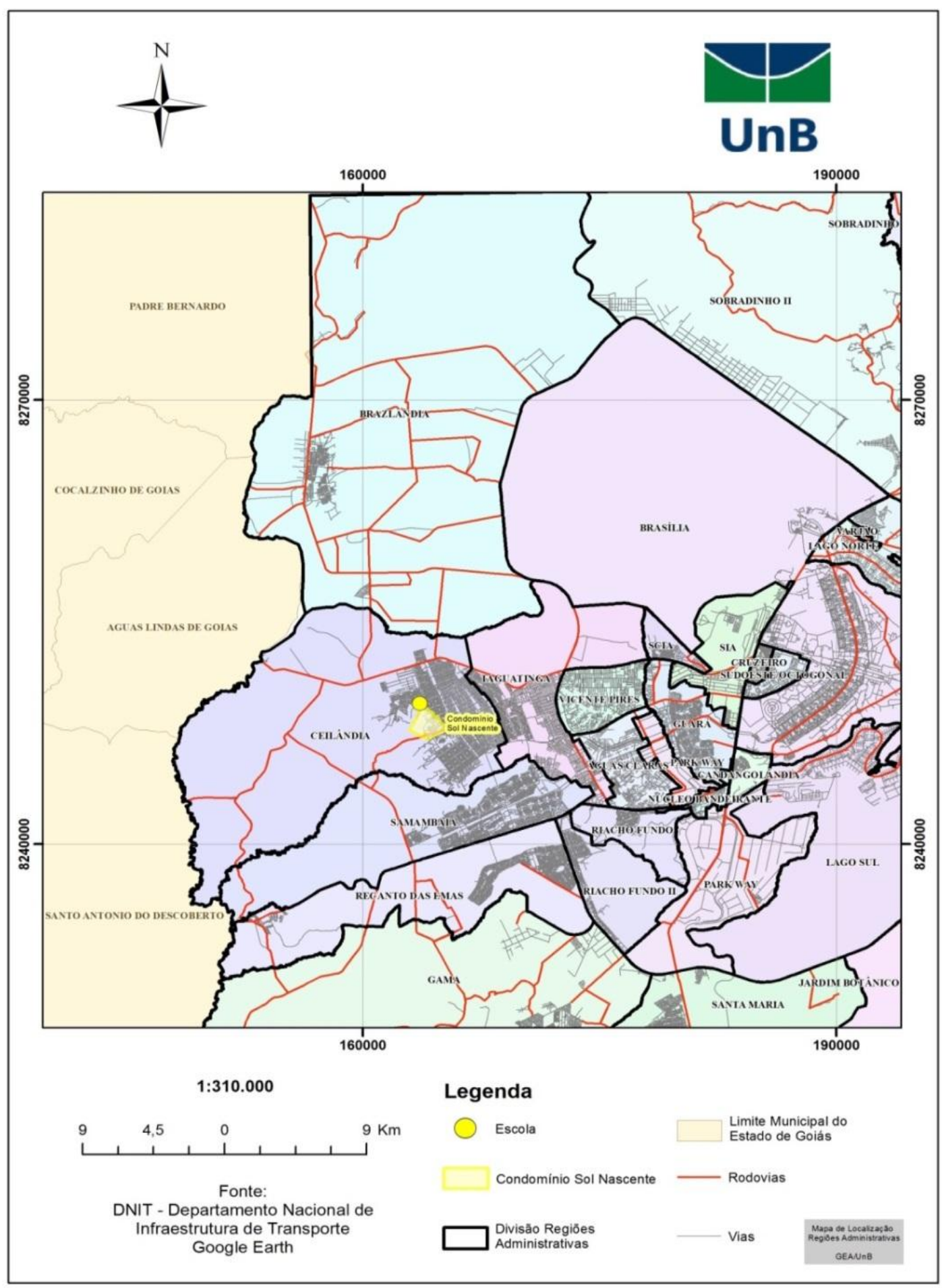

Fonte: Org. José Resende (2014). 
A escola foi criada pela portaria $\mathrm{n}^{\circ} \mathbf{2 8 2}$, de 28/07/2009, publicada no Diário Oficial do Distrito Federal no 145, de 29/07/2009. Por sua dinâmica e proximidade do Condomínio Sol Nascente recebe um grande número de estudantes provenientes dessa localidade. Nesse sentido, os alunos foram sendo transferidos de outras instituições para o CEF-28, com base no critério endereço.

A Secretaria de Estado e Educação e a Coordenação Regional de Ensino de Ceilândia alocaram para essa escola alunos e professores, sem que houvesse uma estrutura completa para recebê-los: falta de materiais básicos para o trabalho pedagógico e administrativo, tais como caneta, giz para quadro negro, papel $A 4$, e até mesmo água potável para se beber. Basicamente existiam somente carteira, quadro negro, alunos matriculados e um quadro restrito de professores efetivos recém-concursados, pois, havia turmas sem professores e a escola ainda estava na expectativa da SEE-DF enviar professores contratados para as vagas de carências definitivas. Enquanto isso os Coordenadores seriam obrigados a lecionar para essas turmas. Ou seja, havia problemas relativos à falta de infraestrutura física e humana, o que causava desespero, desorganização, confusões aos que ali estavam. Por conta de questões administrativas tanto da gestão da escola, quanto da gestão da SEE-DF, a escola ficou dois anos sem receber verbas do Programa Dinheiro Direto na Escola - PDDE $^{2}$ e também do Programa de Descentralização Administrativa Financeira - PDAF $^{3}$. Isso se deu em decorrência da inexperiência das gestões anteriores, contratempos internos, falta de disposição de pessoal e de ajuda da SEE-DF, para implementar um projeto diferenciado de distribuição de verbas para escolas situadas em bairros de vulnerabilidade social e recém inaugurada. Apesar das dificuldades as equipes gestoras se movimentaram com organização de bazares, eventos, rifas de bicicletas e celulares, festas juninas com vendas de alimentos. Tudo isso para

\footnotetext{
${ }^{2} \mathrm{O}$ PDDE tem por finalidade prestar assistência financeira, em caráter suplementar, às escolas públicas da educação básica das redes estaduais, municipais e do Distrito Federal e às escolas privadas de educação especial mantidas por entidades sem fins lucrativos, registradas no Conselho Nacional de Assistência Social (CNAS) como beneficentes de assistência social, ou outras similares de atendimento direto e gratuito ao público. (LEI № 11.947, DE 16 DE JUNHO DE 2009, 2009, p. 1).

3 O PDAF tem como objetivo contribuir na realização do projeto pedagógico, administrativo e financeiro das Instituições Educacionais e das Coordenadorias Regionais de Ensino. A forma de adesão acontece por meio de credenciamento formalizado junto às Coordenadorias Regionais de Ensino, por entidades de pessoa jurídica de direito privado, de fins não-econômicos, legalmente constituídas, e que tenham por finalidade apoiar as Instituições de Ensino - IE's e as Coordenadorias Regionais de Ensino-CRE's no cumprimento das suas respectivas competências e atribuições. Estas entidades são denominadas de Unidades Executoras (UEx), sejam: Associações de Pais e Mestres APM, Associações de Pais, Alunos e Mestres - APAM, Caixas Escolares e demais entidades similares. (PORTARIA N. 134 DE 14/09/2012 - ALTERADA PELA PORTARIA 71 DE 09/04/2013, 2013, p. 1).
} 
sobreviverem às dificuldades do dia-a-dia, como pequenos reparos prediais, conserto e substituições de torneiras, lâmpadas, tempero e sal para a merenda escolar e até mesmo materiais para o apoio pedagógico e administrativo.

Durante os três primeiros anos de funcionamento do CEF-28 teve grandes dificuldades com a aquisição do livro didático, pois, o fechamento do triênio de 2006, onde ocorreu a escolha dos livros didáticos para os anos de 2007, 2008 e 2009, não contemplou a expansão de novas escolas. Consequentemente as escolhas dos livros relativos ao final do triênio de 2009, para os anos 2010, 2011 e 2012, ocorreram entre 09 e 22 de junho de $2009^{4}$, ou seja, antes de inaugurar o CEF-28 de Ceilândia, o que deixou os alunos dessa escola sem apoio do livro didático por 3 anos.

Para solucionar tal situação, os professores que compunham o quadro docente, neste período, e a direção escolar, percorreram as escolas vizinhas, as da região central de Ceilândia, Taguatinga e até escolas de Brasília, em busca de livros, uma vez que essas escolas queriam se desfazer dos livros antigos, do triênio anterior, acumulados em seus depósitos. Desse modo, esses foram repassados ao CEF-28, aceitos pelos professores, na tentativa de minimizar o problema referente a sua falta.

Em relação às tecnologias de multimeios, nessa região de Ceilândia não possuía cobertura de serviços de internet. Em consequência, a escola também não disponha desse serviço e, até hoje, não dispõem de sala de informática equipada, que possa contribuir com as atividades docentes e discentes. Após cinco anos de funcionamento, a SEE-DF providenciou 20 computadores para a escola. Entretanto, com essa quantidade não seria possível atender uma turma, com média de 40 alunos. Nesse sentido, o uso do computador teria que ser partilhado por pares, simultaneamente.

No mês seguinte (novembro 2014) após a entrega de computadores da SEE-DF, o CEF-28 de Ceilândia recebeu um empresário condenado pela Justiça brasileira a prestar serviços comunitários. Esse contribuiu de forma significativa, pois resolveu o problema da insuficiência numérica dos computadores, mediante doação de mais 20 computadores, além de outros equipamentos. Assim, o Laboratório de Informática do CEF-28 de Ceilândia teria condições de atendimento dos 40 alunos por turma. Entretanto, até ao término dessa pesquisa, o laboratório não entrou em funcionamento, pois a escola aguarda o Departamento de Registro de Patrimônio da SEE-DF, para fazer o registro de identificação

\footnotetext{
${ }^{4}$ Informação extraída da página http://portal.mec.gov.br/ acessado em 12/12/2014.
} 
dos bens e a instalação das mesas de apoio para esses computadores. A foto que se segue apresenta o futuro Laboratório de Informática (imagem 2), com computadores sobre mesas escolares, cobertas por tecidos não tecidos-TNT.

\section{Imagem 2 - Futuro Laboratório de Informática do CEF-28.}

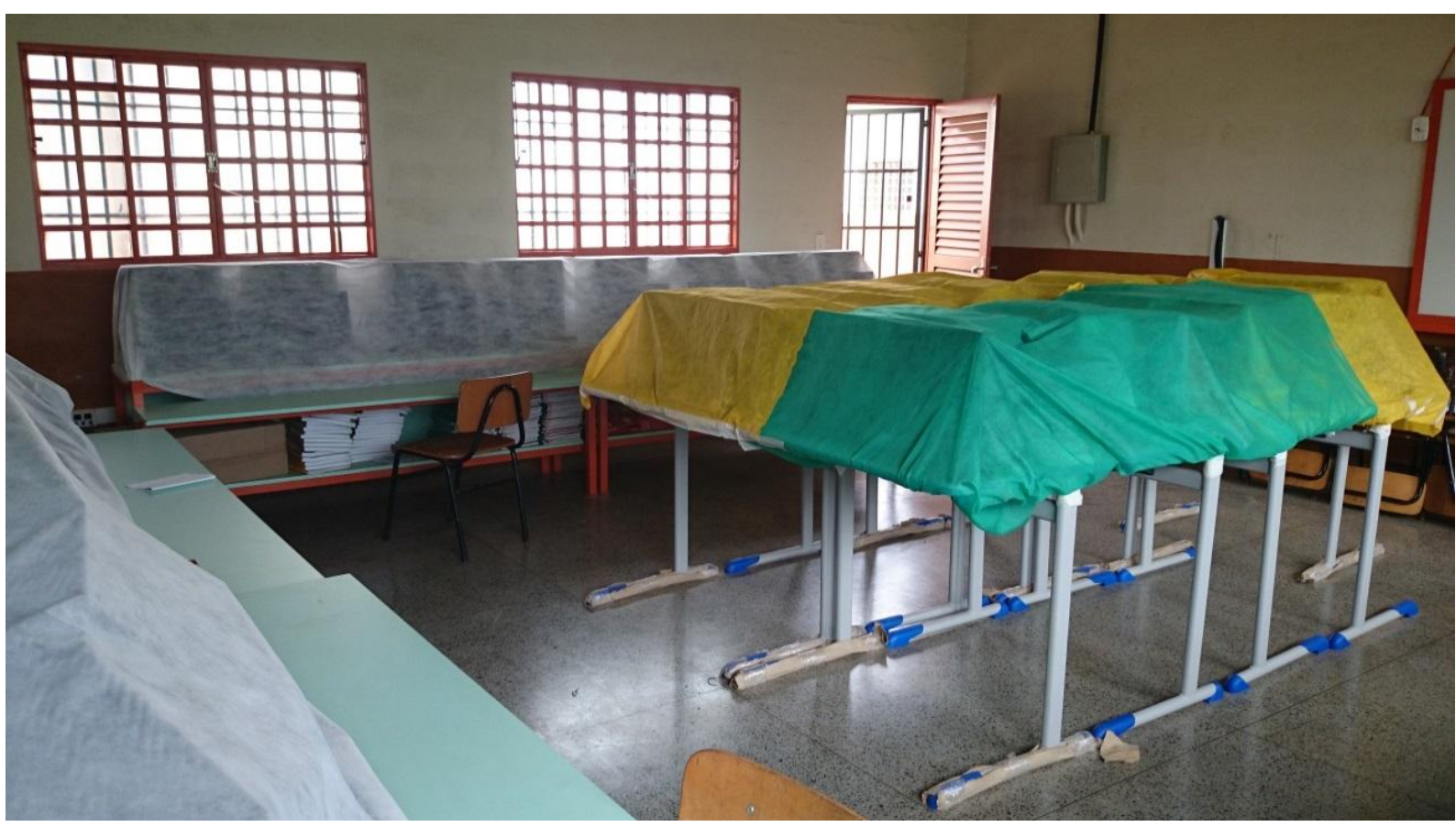

Foto: Silva, A. D (2014)

Outro fator referente às dificuldades da escola encontra-se o tema acesso. Esse, inclusive, constituiu-se um problema que contribuiu para a não permanência dos professores na escola, pois a estrada que conduz à escola não era asfaltada e tinha muitos buracos: muita poeira na época da seca e lama na época chuvosa, como pode ser constatado pelas fotos que se seguem (imagem 3): 


\section{Imagem 3 - estrada de acesso à escola.}

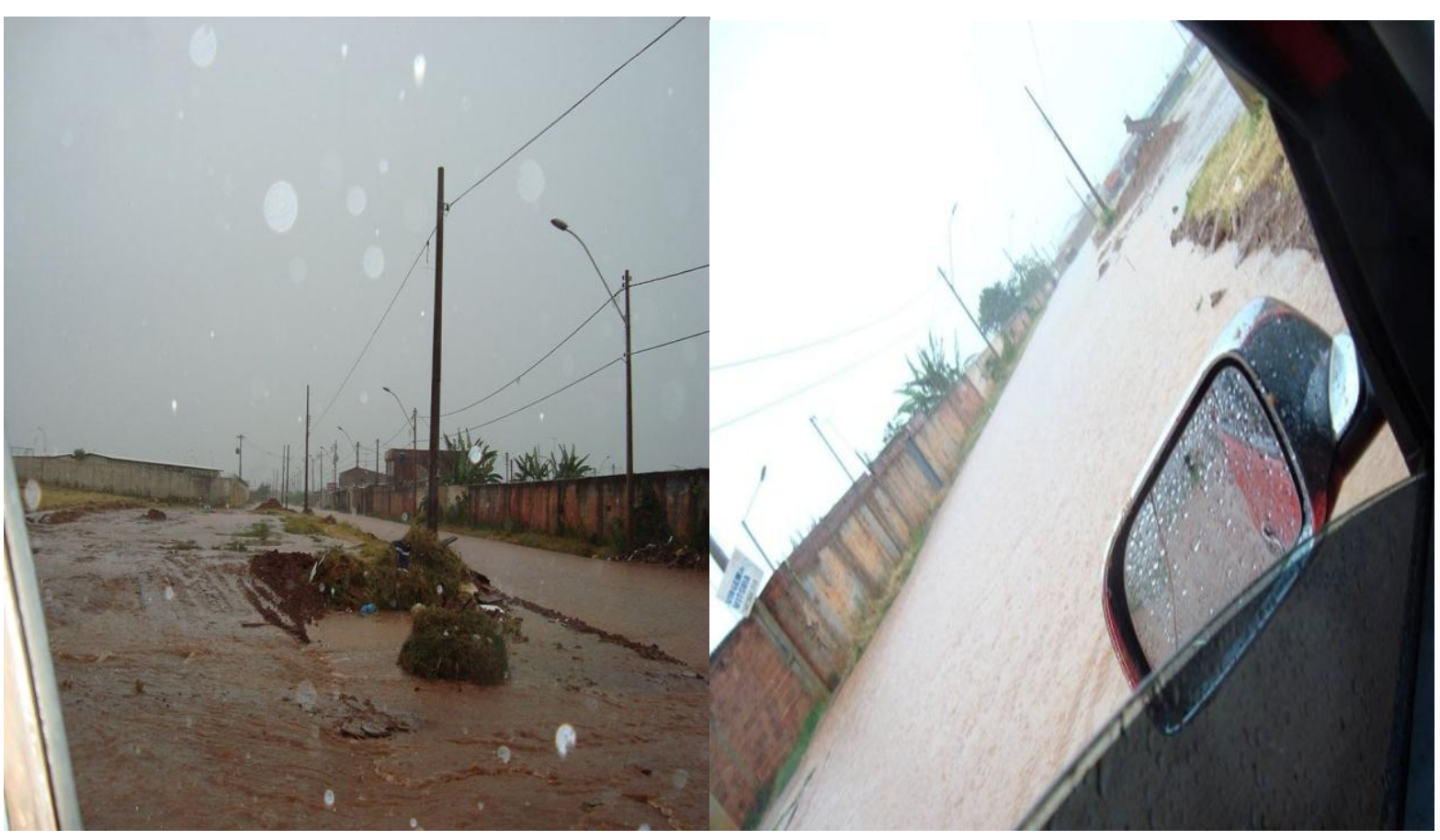

Fotos: Rejane Alencar (2011).

A escola começou a funcionar em Setembro de 2009, em pleno terceiro bimestre do ano letivo, sem nenhuma estrutura administrativa e pedagógica, conforme atestaram os professores que ali estavam. A ausência de estrutura administrativa e os problemas característicos de favela, na região, constituíram-se fatores de fragilidades, que repercutiram diretamente na instituição educacional. Além disso, e de acordo com Reis \& Silva (2013), a escola está próxima da rede de distribuição de narcóticos, o que evidencia a possibilidade de existência de relações sociais com colegas usuários de drogas dentro da escola e, talvez, traficantes. Há falhas, também, nas relações de cooperação entre família e escola. Tal situação, então, poderá desencorajar a permanência dos profissionais neste lugar, levando-os a permanecerem pouco tempo na instituição. Essas situações, por sua vez, repercutem diretamente na construção da identidade da escola.

$\mathrm{Na}$ perspectiva do desenvolvimento da educação, quanto à missão e objetivos institucionais, o Centro de Ensino Fundamental - 28 de Ceilândia:

Busca ofertar uma educação que respeite a cultura de cada aluno, desenvolvendo seu conhecimento acumulado e sua reflexão crítica acerca da realidade que o cerca, incentivando e desenvolvendo o interesse dos alunos pelo estudo e pela educação. Para tanto, busca-se uma mudança de 
concepção dos profissionais que nele atuam, no sentido de fazê-los entender que a escola é para todos e que não deve ser excludente, para tanto o profissional de educação envolvido nesse processo, devem buscar estratégias que possam, por meio da educação, incluir nossos alunos na sociedade. (PPP/CEF-28, 2013, p.11).

Para que aconteça a inclusão dos alunos na sociedade, o PPP/CEF-28 (2013) afirma que é indispensável desenvolver projetos que tornem as aulas mais agradáveis e dinâmicas. Além disso, propõe que o conteúdo trabalhado seja verdadeiramente significativo para o corpo discente, no sentido de viabilizar sua permanência na escola, distanciando-os das ruas e envolvimento com quaisquer outros problemas.

Desta forma, fica evidenciada que a missão do CEF-28 é a formação integral de cidadãos críticos e conscientes, que pensem sobre si e ajam com responsabilidade e respeito com o outro e com o mundo e, ainda, a preparação, não apenas para o mercado de trabalho, mas, principalmente, para a vida.

Em 2013 o Serviço Especializado de Apoio à Aprendizagem - SEAA composta por uma Pedagoga e uma Psicóloga realizou o Mapeamento Institucional que se tornou também um registro da história do CEF-28. Como tal, constituiu-se como importante fator de compreensão à dinâmica da escola, conforme pode ser constatado a seguir.

Quanto às instalações físicas, em conformidade com o Mapeamento Institucional, o CEF-28 de Ceilândia (mapa 2, imagens 4,5,6) dispõe de:

1. 04 Blocos contendo 06 salas de aula e perfazendo um total de 24 salas de aula;

2. 01 Bloco contendo dependências administrativas: 01 sala de Direção, 01 sala de apoio, 01 sala de Professores, 01 Banheiro Masculino e 01 Banheiro Feminino para os Professores, 01 Secretaria, 01 sala para Serviço Especializado de Apoio Pedagógico e 02 banheiros coletivos masculino e feminino para os alunos e 01 cozinha com 01 depósito de alimentos;

3. 01 Bloco com salas de apoio pedagógico: sala de vídeo, sala de ciências, sala de leitura, sala de coordenação para professores e sala de apoio para pessoal da limpeza;

4. O CEF-28 possui uma quadra para a prática de esportes e recreação, porém, a mesma não é coberta, o que dificulta muito a realização de atividades pedagógicas em tempo de sol ou de chuva; 
5. O CEF-28 possui um parquinho para o atendimento das crianças até o $3^{\circ}$ Ano Ensino Fundamental.

Imagem 4 - Bloco de sala de aulas.

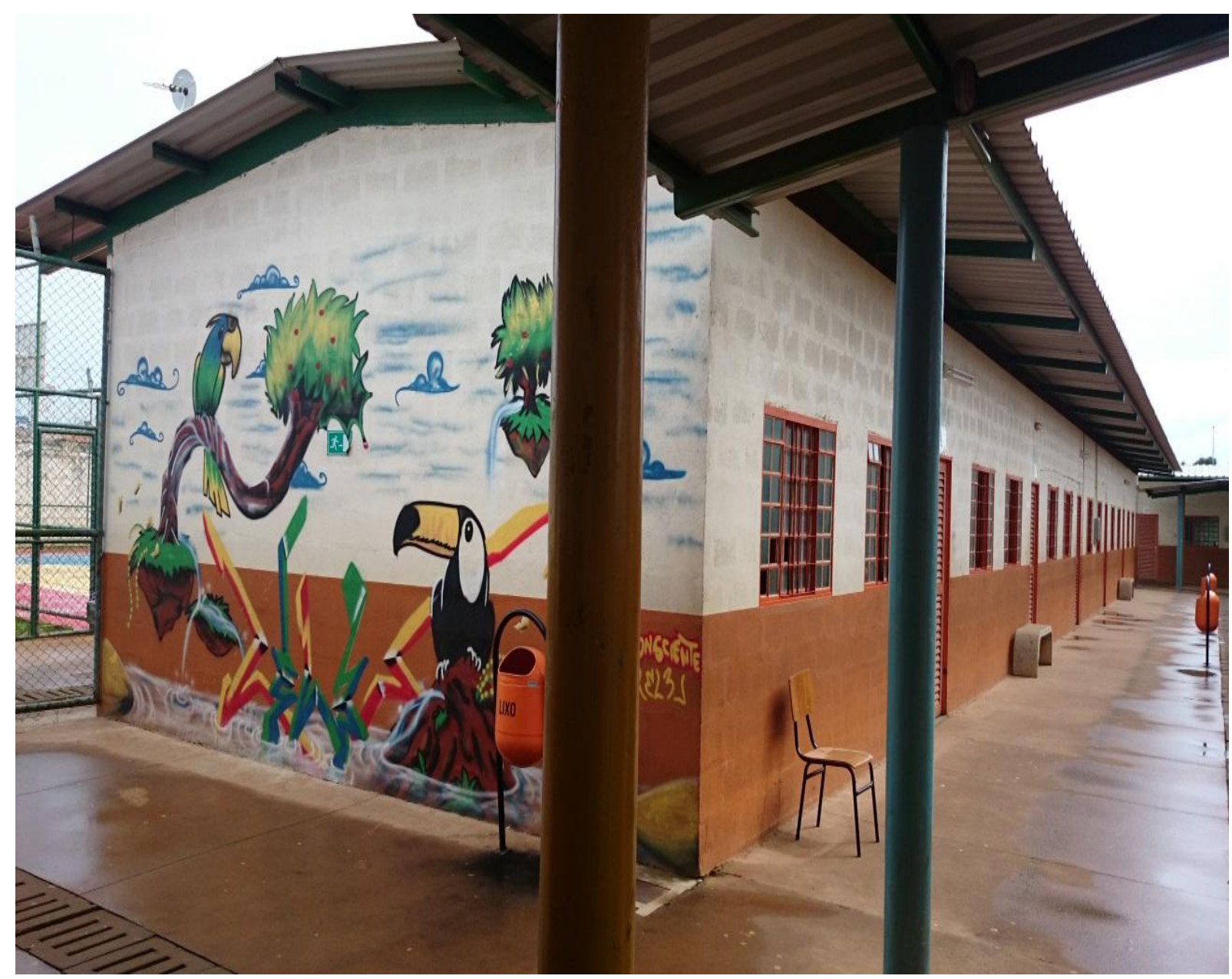

Foto: Silva, A. D (2014). 


\section{Imagem 5 - Espaçamento entre blocos}

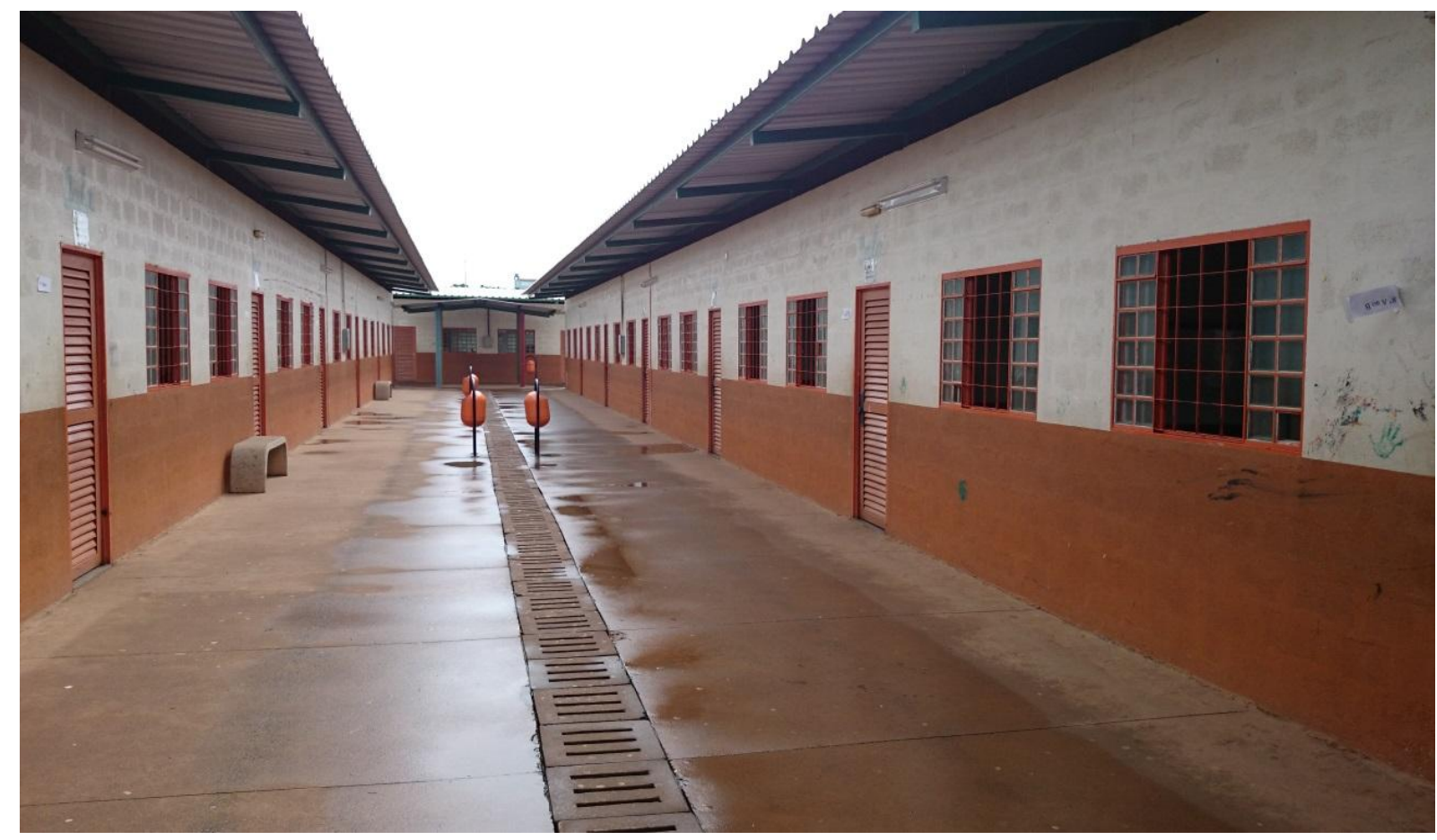

Foto: Silva, A. D (2014).

Imagem 6 - Disposição dos blocos do CEF-28 de Ceilândia.

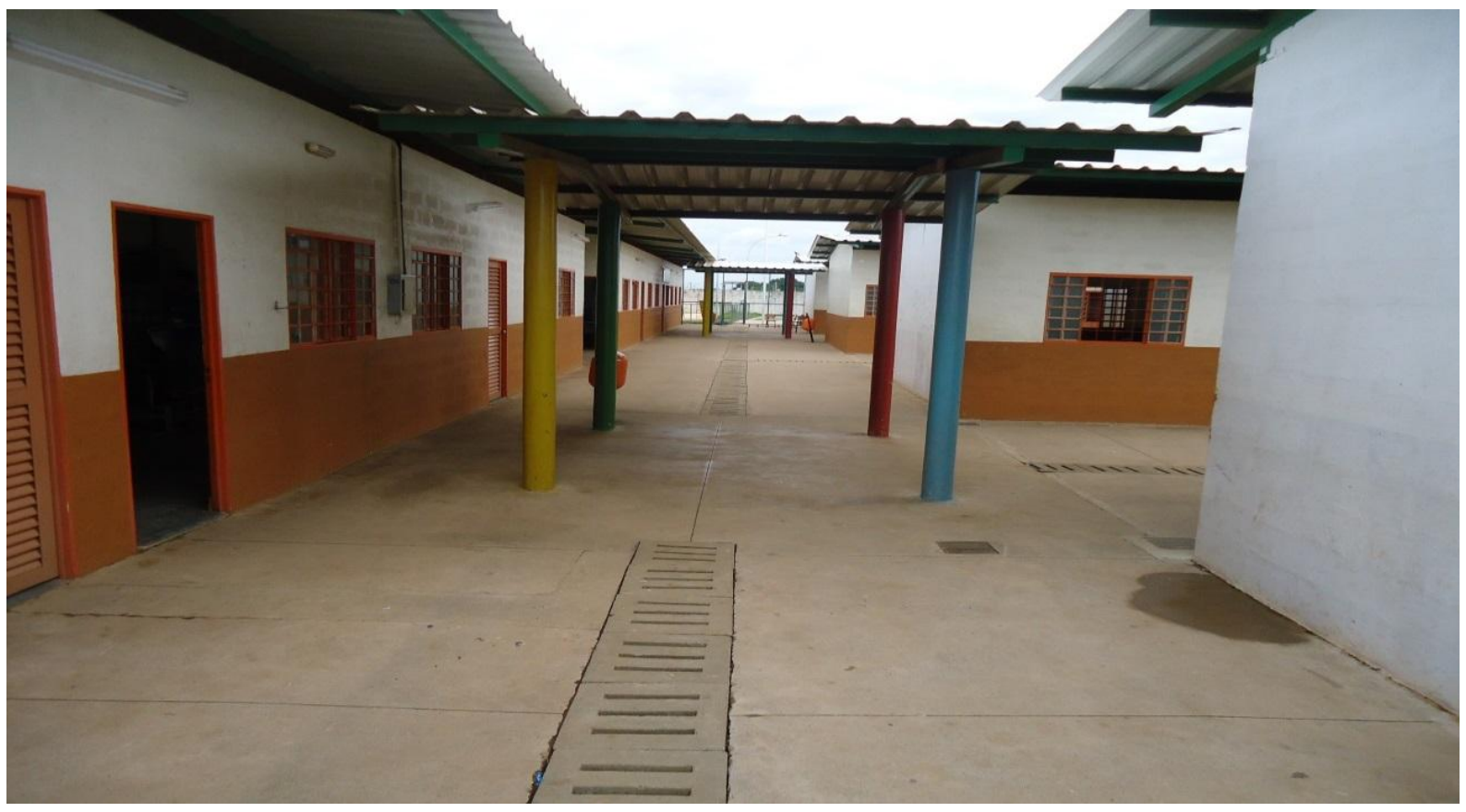

Foto: Silva, A. D (2014). 
Mapa 2- Área e disposição do Centro de Ensino Fundamental 28 de Ceilândia.

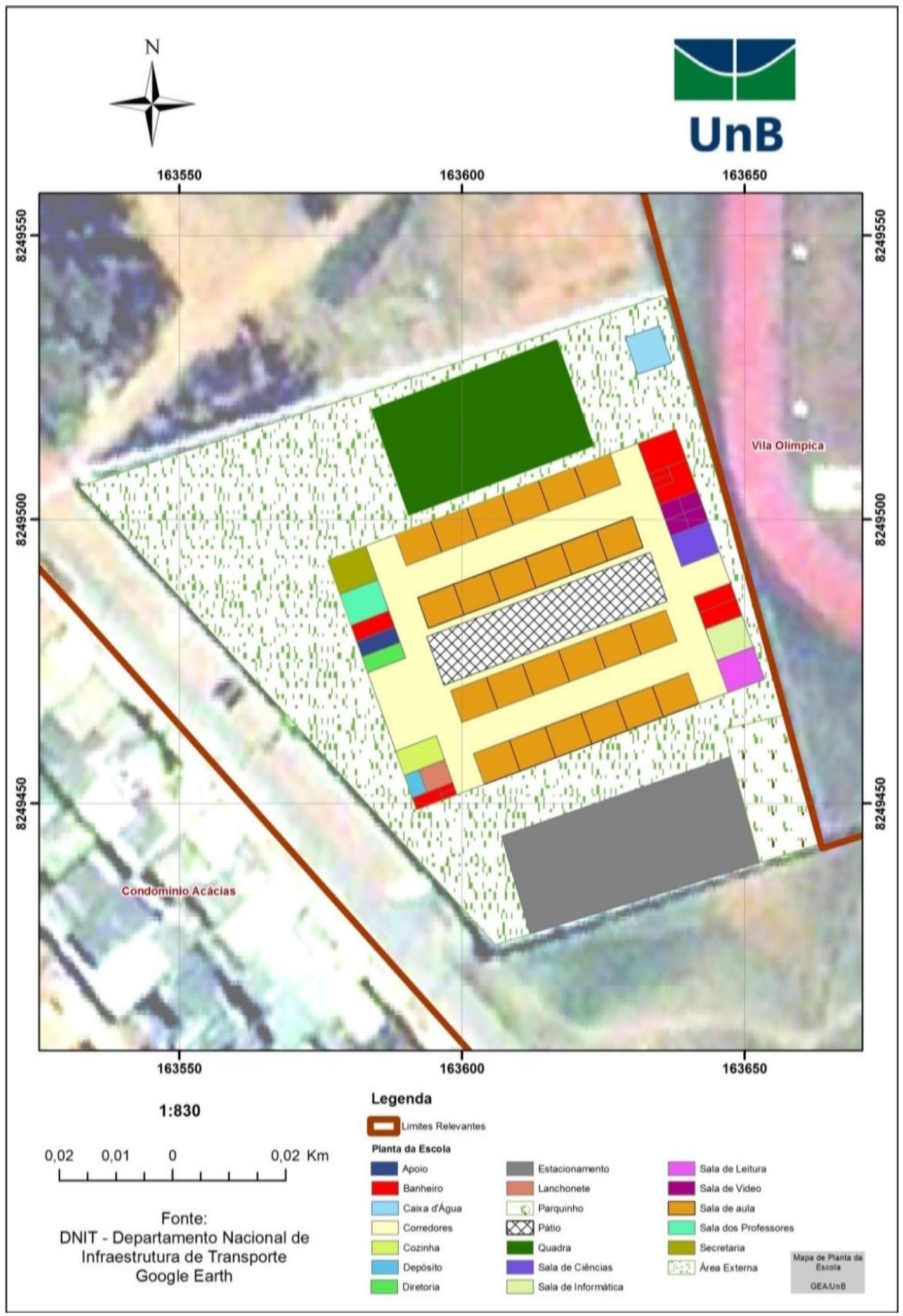

Org. José Resende (2014). 
O documento de Mapeamento Institucional aponta que:

Para uma escola recém construída, a estrutura física do CEF-28 apresenta uma disposição desfavorável para uma escola e não atende completamente às necessidades dos quase aproximadamente 1.400 alunos. $E$ a estrutura física também vem apresentando inúmeros problemas de construção que causam tumultos no dia a dia escolar, como: falta de água, problemas na condução da energia elétrica, portas que se estragam com facilidade, falta de local coberto para realização de atividades culturais e pedagógicas. (MAPEAMENTO INSTITUCIONAL DO CEF-28, 2014, p. 5).

Assim, é provável que os problemas relacionados à estrutura física da escola, à falta de recursos pedagógicos, à violência cotidiana e demais problemas ligados à pobreza do lugar, estejam relacionados à alta rotatividade de professores na escola, que ainda não dispõe de um corpo de profissionais efetivos. Tal ideia é endossada pelo mapeamento institucional:

[...] Nossa escola é nova na região, ainda estamos mapeando o perfil da clientela. Até o momento, houve um grande rodízio de profissionais na unidade escolar, por conta de muitos entraves administrativos, concursos, contratos temporários, rodízio de direção e muito medo por parte dos profissionais efetivos que não desejam viver essa realidade em seu cotidiano. (MAPEAMENTO INSTITUCIONAL DO CEF-28, 2014, p. 3).

A despeito dessa situação, percebe-se que apesar das dificuldades impostas ao dia a dia escolar, o Mapeamento Institucional do CEF-28 aponta uma esperança de cumprimento da função social da escola: a formação de cidadãos críticos, reflexivos, autônomos, conscientes de seus direitos e deveres e que possam entender a realidade de sua vivência e participar das decisões sociais, econômicas e políticas para melhoria do seu lugar.

Acreditamos que, em médio prazo, é possível atuar nas fragilidades do
CEF-28, uma vez que a equipe técnica, em sua maioria, compreende que a
escola é também um centro de intervenção social. Decerto, conhecer,
inicialmente, o perfil da nossa comunidade é um importante passo para
identificar não somente as suas fragilidades, mas também as suas
potencialidades e os seus objetivos. É preciso acreditar que, enquanto
mediadores, mas também referenciais para as nossas crianças e
adolescentes e, por meio da educação, há "uma luz no fim do túnel", uma
maneira de transpor a pobreza, a carência afetiva, a violência doméstica e
contribuir com as vidas dos alunos e de suas famílias. (MAPEAMENTO
INSTITUCIONAL DO CEF-28, 2014, p.5).

A composição de quantitativo de alunos e professores no período de 2013 e 2014, encontra-se especificado nos quadros que se seguem. 


\section{Quadro 2 - Quantitativo de professores do CEF-28 nos anos de 2013 e 2014.}

\begin{tabular}{|l|l|l|}
\hline Especificação & 2013 & 2014 \\
\hline Total de professores efetivos & 48 & 34 \\
\hline Total de professores contratados & 19 & 22 \\
\hline
\end{tabular}

Fonte: Mapeamento Institucional do CEF-28 / 2014. (Organização: Silva, A. D).

Quadro 3- Quantitativo de alunos por turmas do CEF-28 período de 2012 e 2013.

\begin{tabular}{|c|c|c|c|c|c|c|c|c|c|c|}
\hline Anos & $1^{\circ}$ & $2^{\circ}$ & 30 & $4^{\circ}$ & $5^{\circ}$ & $6^{\circ}$ & $7^{\circ}$ & $8^{\circ}$ & 9 & TOTAL \\
\hline 2012 & 110 & 86 & 106 & 76 & 50 & 344 & 193 & 150 & 86 & 1201 \\
\hline 2013 & 21 & 86 & 106 & 76 & 50 & 384 & 226 & 136 & 134 & 1219 \\
\hline
\end{tabular}

Fonte: Secretaria Escolar do CEF-28 / (Organização: Silva, A. D).

\section{Quadro 4 - Alunos ANEE ${ }^{5}$ e classes inclusivas do CEF-28 período de 2013.}

\begin{tabular}{|l|l|}
\hline \multicolumn{1}{|c|}{ Especificação } & \multicolumn{1}{|c|}{2013} \\
\hline Total de alunos ANEE séries iniciais & 08 \\
\hline Total de alunos ANEE TGD & 01 \\
\hline Total de turmas com integração inversa $^{6}$ & 02 \\
\hline Total de classe comum inclusiva $^{7}$ & 02 \\
\hline
\end{tabular}

Fonte: Mapeamento Institucional do CEF-28 / 2014. (Organização: Silva, A. D).

Na escola funciona uma Secretaria Administrativa que cuida da documentação da vida escolar dos alunos, com uma equipe composta por uma secretária e dois auxiliares.

\footnotetext{
${ }^{5}$ Os alunos ANEE são Alunos Portadores de Necessidades Especiais, que na SEE-DF possuem uma organização especial do processo de matrícula até a inserção e acompanhamento da aprendizagem dentro da instituição escolar.

${ }^{6}$ No DECRETO No 22.912, DE 25 DE ABRIL DE 2002 no Art. 2 inciso II afirma que, turmas com integração inversa são para atendimento, em caráter transitório, a alunos que apresentem dificuldades acentuadas de aprendizagem ou condições de comunicação e sinalização diferenciados dos demais alunos, e demandem ajudas e apoios intensos e contínuos. Classes de Integração Inversa, cuja constituição obedeça à proporção de $1 / 3$ de alunos normais, nas áreas de Deficiência Mental, Deficiência Auditiva, Deficiência Física e Condutas Típicas de Síndromes.

${ }^{7}$ De acordo com a Estratégia de Matrícula da SEE-DF 2013, a Classe Comum Inclusiva é constituída por estudantes com ou sem deficiências, Transtorno Global do Desenvolvimento (TGD) e altas habilidades/superdotação, conforme modulação para cada etapa de ensino.
} 
Ainda há as equipes de apoio aos professores e estudantes, composta de uma professora de Sala de Recursos, o Serviço Especializado de Apoio à Aprendizagem / SEAA, composto por uma Pedagoga e uma Psicóloga e uma Orientadora Educacional, sendo que os dois primeiros serviços, só atendem aos alunos de $1^{\circ}$ ao $5^{\circ}$ Ano.

Em relação ao desempenho escolar dos alunos é preocupante o cenário de reprovações, conforme pode ser constatado nos gráficos que se seguem. Importante esclarecer, que para fins desta pesquisa, procurou-se ilustrar o quadro de reprovações do total de alunos do CEF-28 nos anos letivos de 2012 e 2013.

\section{Gráfico 1- alunos reprovados em $2012^{8}$.}

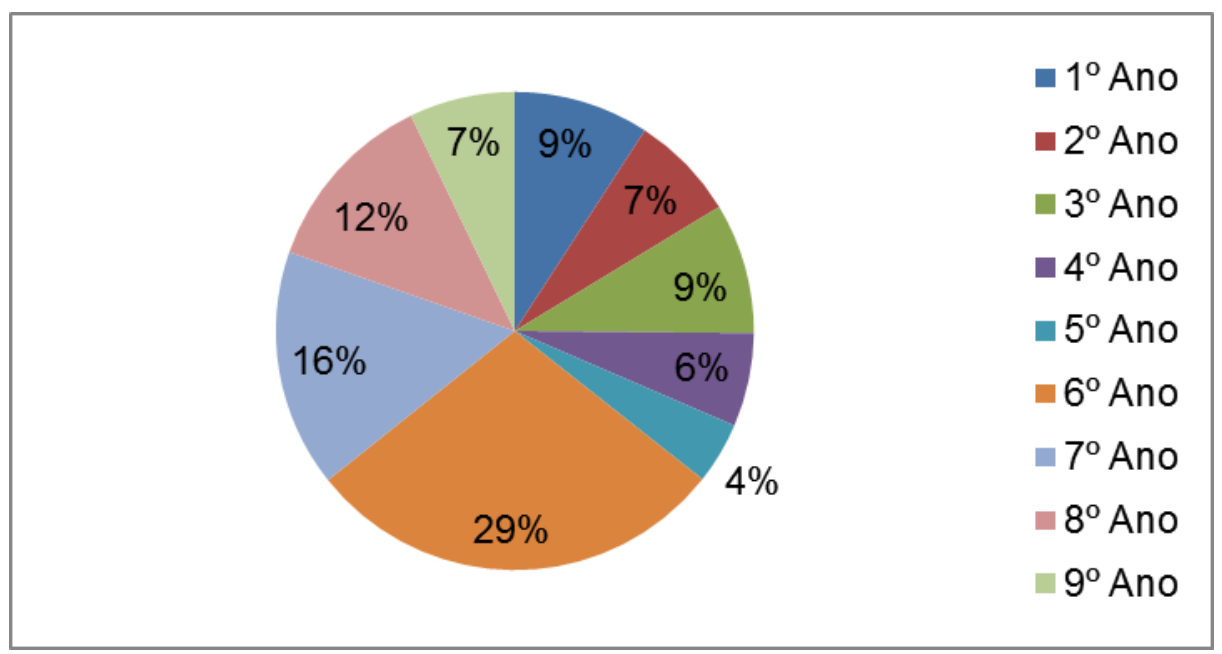

Fonte: Secretaria Escolar do CEF-28 / (Organização: Silva, A. D).

As taxas de reprovação dos anos iniciais são menores quando comparados às dos anos finais do Ensino Fundamental. Isso pode ser explicado pela política educacional aplicada aos anos iniciais desde 2006, inicialmente em Ceilândia e depois estendida para todas as outras Regionais de Ensino, principalmente por meio da implementação do Bloco Inicial de Alfabetização - BIA,

O BIA apresenta uma organização escolar em ciclos de aprendizagem, assim, preconiza uma unidade escolar que proporcione o avanço de todos com a qualidade de aprendizagem e respeito às questões individuais dessas aprendizagens. O Distrito Federal adotou a progressão continuada no Bloco defendendo a não retenção dos alunos nos anos iniciais da alfabetização, na direção do que é defendido e preconizado pelo Ministério da Educação. (DIRETRIZES PEDAGÓGICA DO BLOCO INICIAL DE ALFABETIZAÇÃO, 2012, p. 10).

\footnotetext{
${ }^{8}$ Nesta pesquisa os dados sobre o quantitativo de alunos reprovados em 2012, tem como propósito a comparação com as reprovações do ano de 2013.
} 
De acordo com o documento supracitado, a organização escolar para as séries iniciais consideram que o trabalho pedagógico deve estar voltado para as necessidades de aprendizagem de todos os estudantes e com a garantia de um processo contínuo de aprendizagem; que os estudantes no bloco têm progressão do $1^{\circ}$ ano para o $2^{\circ}$ ano, e deste para o 3ำ ano; uma garantia de respeito aos tempos de desenvolvimento do estudante nos primeiros anos escolares e, ainda, que a retenção só acontecerá ao final do ciclo, no 3ํano do BIA.

No intuito de comparação buscou-se, também, os índices de reprovação no ano letivo de 2013, apresentados no gráfico que se segue.

\section{Gráfico 2- Alunos reprovados em 2013}

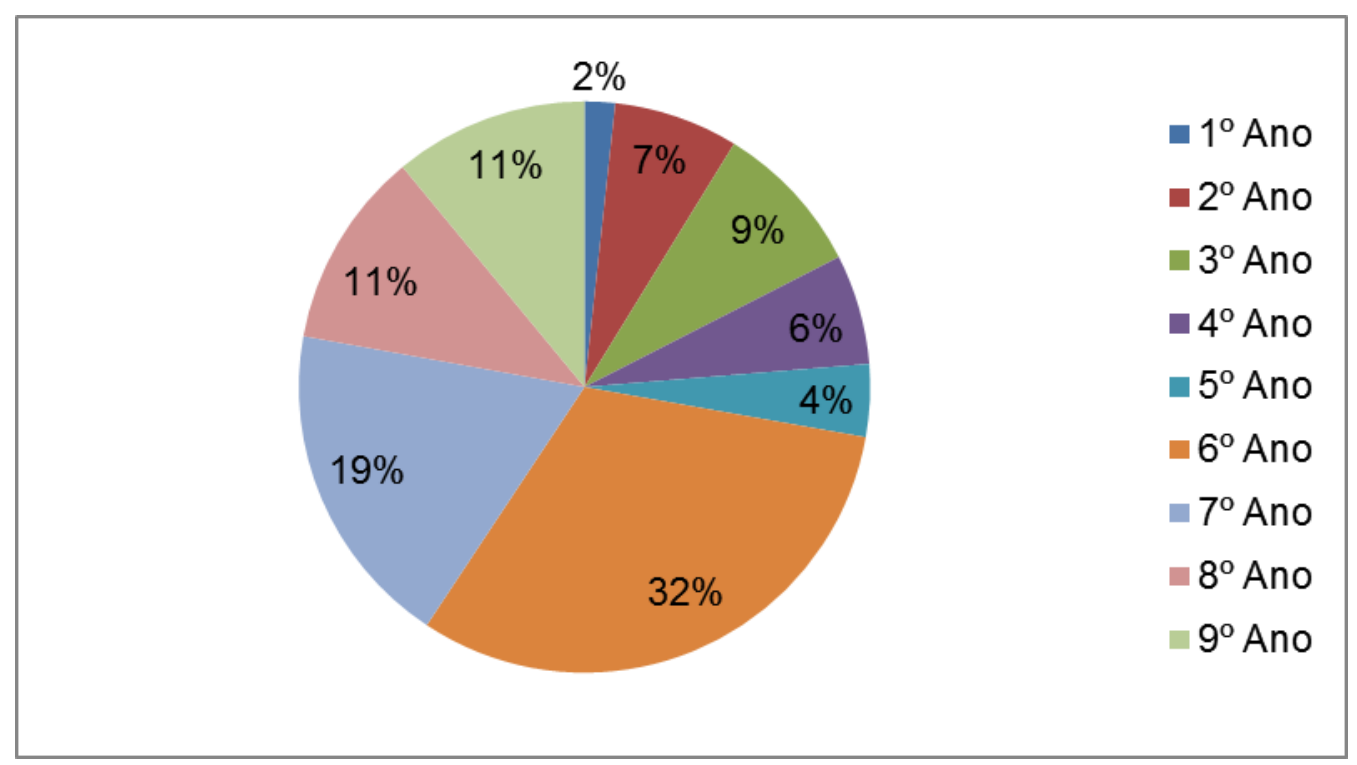

Fonte: Secretaria escolar do CEF-28 / (Organização: Silva, A. D).

De acordo com os gráficos 1 e 2 acima, pode-se constatar que houve um acréscimo na reprovação em relação 2012 a 2013, principalmente em relação ao 6ํano, momento em que os alunos enfrentam um mudança significativa no padrão de sua escolarização: dispõem, não mais, de apenas um(a) professor(a), mas de vários, para distintos campos disciplinares. 


\section{Quadro 5 - Taxa de reprovação por série e disciplina 2013.}

\begin{tabular}{|c|c|c|c|c|c|c|c|c|}
\hline Disciplina & Arte & Ciências & $\begin{array}{l}\text { Ed. } \\
\text { Física }\end{array}$ & Geografia & História & Inglês & $\begin{array}{l}\text { Língua } \\
\text { Portuguesa }\end{array}$ & $\begin{array}{l}\text { Matemá } \\
\text { tica }\end{array}$ \\
\hline \multicolumn{9}{|l|}{ Turmas } \\
\hline $6^{\circ}$ & $\begin{array}{l}24,74 \\
\%\end{array}$ & $26,04 \%$ & $19,8 \%$ & $29,4 \%$ & $25 \%$ & $22,9 \%$ & $29,68 \%$ & $29,16 \%$ \\
\hline $7^{\circ}$ & $\begin{array}{l}12,83 \\
\%\end{array}$ & $18,14 \%$ & $9,3 \%$ & $19,63 \%$ & $17,25 \%$ & $19,46 \%$ & $14,15 \%$ & $17,25 \%$ \\
\hline $8^{\circ}$ & $\begin{array}{l}14,70 \\
\%\end{array}$ & $34,55 \%$ & $7,35 \%$ & $13,60 \%$ & $42,64 \%$ & $28,67 \%$ & $30,88 \%$ & $15,44 \%$ \\
\hline $9^{\circ}$ & $9,7 \%$ & $13,43 \%$ & $6,71 \%$ & $8,8 \%$ & $14,92 \%$ & $12,68 \%$ & $14,17 \%$ & 8,20 \\
\hline
\end{tabular}

Fonte: Secretaria escolar do CEF-28 / (Organização: Silva, A. D).

Ao observar os quadros que trazem o quantitativo de alunos matriculados e taxa de reprovação por turmas em 2013, percebe-se que a turma de $6^{\circ}$ ano na disciplina de Geografia obteve a segunda maior taxa de reprovação, perdendo somente para a disciplina de matemática, o que reforça o comentário anterior, de mudança nos padrões de escolarização entre os anos iniciais e os anos finais de escolarização. Interessante destacar, ainda, o fato do $7^{\circ}$ ano apresentar a maior taxa de reprovação na disciplina Geografia.

Por fim, no processo de caracterização da escola, de seus professores e alunos, merece destaque o fato de que o CEF-28 apresenta elevadas taxas de desistência, conforme pode ser observado no gráfico que se segue.

\section{Gráfico 3 - Alunos desistentes}

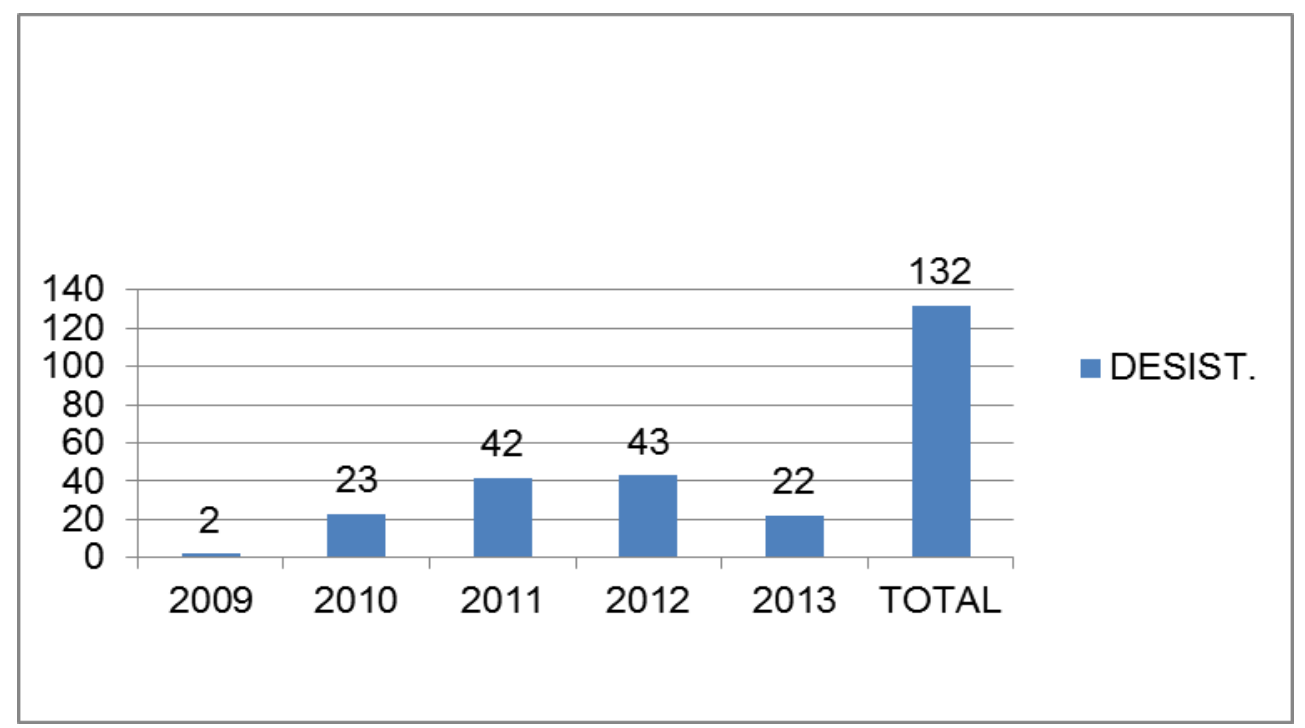

Fonte: Secretaria escolar do CEF-28 de Ceilândia / (Organização: Silva, A. D). 
A importância dessa informação reside no fato de que esses dados de desistência enquadram-se no elenco das estatísticas referentes à reprovação, de um lado, e evidenciam uma situação de vulnerabilidade social dos estudantes, de outro.

\subsection{3 - Participantes da pesquisa: os professores de Geografia do CEF- 28 e a sua rotina de trabalho.}

Os participantes desta investigação são professores de Geografia que lecionam para as turmas do $6^{\circ}$ ao $9^{\circ}$, conforme especificação que se segue:

\section{Quadro 6- Caracterização dos participantes da pesquisa}

\begin{tabular}{|c|c|c|c|c|c|c|}
\hline Especificação & Formação & \multicolumn{2}{|c|}{ Local } & $\begin{array}{c}\text { Situação } \\
\text { junto a } \\
\text { SEE-DF }\end{array}$ & $\begin{array}{c}\text { Tempo } \\
\text { de } \\
\text { serviço } \\
\text { na } \\
\text { escola }\end{array}$ & $\begin{array}{c}\text { Tempo de } \\
\text { experiência } \\
\text { com } \\
\text { educação }\end{array}$ \\
\cline { 3 - 6 } & $\begin{array}{c}\text { Nascimento } \\
\text { Professor 1 }\end{array}$ & $\begin{array}{c}\text { - - Gós } \\
\text { graduação } \\
\text { em } \\
\text { Orientação } \\
\text { Educacional }\end{array}$ & Gama-DF & $\begin{array}{c}\text { Ceilândia- } \\
\text { DF }\end{array}$ & Efetivo & 21 anos \\
\hline Professor 2 & $\begin{array}{c}\text { - Geografia } \\
\text { Professor 3 }\end{array}$ & $\begin{array}{c}\text { Santo André- } \\
\text { SP }\end{array}$ & $\begin{array}{c}\text { Vicente } \\
\text { Pires-DF }\end{array}$ & Efetivo & 6 meses & 15 anos \\
\hline Professor 4 & - Geografia & Araguaçu-TO & Ceilândia & Efetivo & 6 meses & 2 anos \\
\hline
\end{tabular}

Pode-se observar, que todos os professores de Geografia do CEF- 28 são efetivos da Secretaria de Educação e, majoritariamente, moradores de Ceilândia e com pouco tempo de exercício nesta escola. Também, pode-se perceber que nenhum teve como local de nascimento a região de seu trabalho. 
Para a realização desta pesquisa foram distribuídos quatro questionários e realizadas quatro entrevistas com aqueles professores (graduados em Licenciatura Plena em Geografia, concursados efetivos ${ }^{9}$ da SEE-DF, lotados no CEF- 28 da Ceilândia).

Os professores dessa escola, que foram pesquisados, trabalham do $6^{\circ}$ ao $9^{\circ}$ e tem, em média, seis turmas com aproximadamente 35 alunos distribuídos nos períodos matutino e vespertino.

Durante o ano letivo a evasão e a transferência de alunos é algo comum e as turmas podem ou não diminuir para 32 alunos. A movimentação de transferências e matrículas é constante e rotineira. O número total de alunos da escola se altera quase que diariamente. Esse dado se torna importante para este estudo, no sentido de possibilitar a compreensão da complexidade da migração das famílias e consequentemente dos alunos, que em sua maioria são compostas de famílias provenientes do Nordeste brasileiro, especialmente dos Estados do Maranhão, com 18,67\%, e Piauí, com 16,33\%, segundo dados da CODEPLAN (2013).

A rotina anual dos professores da SEE-DF é traçada por um calendário escolar aprovado pela SEE-DF e Conselho de Educação do DF, após passar pelo processo de consulta pública aos professores através do site do Sindicato dos Professores do Distrito Federal.

A rotina semanal do trabalho dos professores do DF contratados por 40 horas é assim demarcada: aulas no turno matutino das $7 \mathrm{~h} 30$ às $12 \mathrm{~h} 30$ e no turno vespertino das $13 \mathrm{~h}$ às 18hs. A carga horária anual é de 1000 horas/aula. Se o professor ministra aulas no turno matutino, no contra turno o seu tempo durante três manhãs, ou três tardes, por exemplo, será destinado à organização e planejamento pedagógico individual ou coletivo. Os dois outros dias ficam destinados ao trabalho pedagógico externo, isto é, fora do ambiente

\footnotetext{
${ }^{9}$ NOTA DO AUTOR: No CEF-28 de Ceilândia até o fechamento dessa pesquisa a escola encontra-se com alta rotatividade de professores substitutos e efetivos. A rotatividade dos substitutos se deve ao fato de não gerar vínculo empregatício e o mesmo acontece mediante a necessidade exclusiva para suprir a falta de docente da carreira por decorrência de vagas temporárias e afastamentos legais dos titulares. Os professores efetivos tem o direito de participar de concursos de remoção interna, que compreende a mesma Regional de lotação, ou externa, quando objetivam transferência para outra Regional. Vale ressaltar que o professor efetivo, no primeiro ano de posse do cargo público, não possui lotação definitiva, ou seja, todos devem participar do processo de remanejamento, para que, a partir do segundo ano, conquiste lotação definitiva na escola e Regional de Ensino de seu interesse. Entretanto, muitas vezes o docente não se adapta à realidade da escola escolhida e, no ano seguinte, volta a participar do processo de remanejamento. Dessa forma as escolas novas, notadamente as problemáticas, tem alta rotatividade de pessoal, o que dificulta a construção de sua identidade.
} 
escolar. Os professores são incentivados a participarem de cursos de formação continuada presenciais ou a distância, ofertados pela Escola de Aperfeiçoamento dos Profissionais da Educação/EAPE. Desse modo, podem utilizar uma de suas coordenações individuais para participação em cursos, uma estratégia que fortalece a qualidade da formação docente do Distrito Federal. Essa rotina é normatizada pela Portaria SEE-DF № 12 de 24 de Janeiro de 2014.

Durante o trabalho pedagógico semanal nas reuniões dos contra turnos, os professores se reúnem para realizar trabalhos de preenchimento de relatórios, diários, organização das notas de alunos, elaboração de avaliações, pesquisa bibliográfica, organização de material pedagógico para as aulas, entre outras atividades pedagógicas. Observa se que grande parte do trabalho do professor é dedicada ao preenchimento dos diários de classe, pois em sua maioria e dependendo da carga horária e das disciplinas, um professor chega a ter dez diários de classe, ou seja, em média, um professor possui em torno de 350 alunos.

Com relação à distribuição de carga horária das disciplinas no CEF-28, fica assim estabelecido: quatro aulas de Língua Portuguesa, quatro aulas de Matemática, duas aulas de Geografia, duas aulas de História, duas aulas de Inglês, duas aulas de Educação Física, duas aulas de Ciências Naturais, que fazem parte das disciplinas obrigatórias do currículo escolar. Existe ainda uma aula de Prática Diversificada/PD, disciplina ministrada por professores que não tiveram sua grade de carga horária fechada com sua disciplina de habilitação. Por exemplo, se na escola não houve turmas suficientes para fechar a carga horária obrigatória do professor de Geografia, ele, é obrigado a lecionar a disciplina de PD para completar sua carga horária. Nesta disciplina, o professor elabora projetos com Temas Transversais $^{10}$ importantes e necessários à formação do aluno. A escolha das turmas de cada professor é feita durante um concurso interno, no início do ano letivo, regido por critérios de uma portaria publicada anualmente pela SEE-DF.

Semanalmente os professores se reúnem em seu horário de contra turno, também para organizar o trabalho pedagógico coletivo, ou seja, organizar projetos pedagógicos em

10 Os Temas Transversais são assim qualificados por não pertencerem a nenhuma disciplina específica, mas atravessarem todas elas como se a todas fossem pertinentes. Eles fazem parte dos Parâmetros Curriculares Nacionais (PCN's), criados a partir do Plano Nacional de Educação (PNE), estabelecido em 1999, os quais não constituem uma imposição de conteúdos a serem ministrados nas escolas. São apenas propostas nas quais as secretarias e as unidades escolares poderão se basear para elaborar seus próprios planos de ensino. 
comum, festividades, ter momentos de formação e organização de documentos oficiais, necessários ao andamento e construção do projeto pedagógico escolar, como por exemplo, o PPP e os Planos de Ensino. Estas atividades em contra turno são apoiadas e organizadas juntamente com o Supervisor Pedagógico, que no CEF-28 de Ceilândia, é somente uma pessoa para um total de aproximadamente 1600 alunos (da Escola Classe, $1^{\circ}$ ao $5^{\circ}$ ano, e do Centro de Ensino Fundamental, 6ำ ao 9o ano). Na Escola Classe participam dessa organização a psicóloga e a pedagoga do SEAA, a Orientadora Educacional e a professora da Sala de Recursos, que atende aos alunos com necessidades especiais educacionais, e um coordenador pedagógico. Já para o Centro de Ensino Fundamental, participam das reuniões, além do Supervisor Pedagógico, três coordenadores pedagógicos e um Orientador Educacional. Não existem na SEE-DF equipes de apoio aos alunos com necessidades especiais.

Desse relato se depreende que os professores lotados no CEF-28 de Ceilândia, ao chegarem ali, precisam aprender a lidar com as peculiaridades e com as complexidades próprias da escola, que foram aumentadas em virtude do quantitativo de alunos, do número reduzido de pessoal de apoio extraclasse e também pela falta de apoio pedagógico aos alunos com necessidades especiais, com dificuldades disciplinares e com dificuldades de aprendizagem. O professor, sobrecarregado em suas funções, fica de pés e mãos atados para atender alunos com necessidades complexas, próprias dos adolescentes, como por exemplo, estabelecer vínculos pessoais para ajudá-los a superar suas reais dificuldades de aprendizagem.

A SEE-DF, por sua vez, trata as escolas da periferia e ou de áreas em setores com vulnerabilidade social, com as mesmas regras, normas, regulamentações e quantitativo de verbas que aquelas que não sofrem com essa complexidade. Desse modo, no CEF-28 de Ceilândia, por exemplo, não existe pessoal para apoiar os professores em projetos extraclasse, nem tampouco na organização da disciplina dos alunos durante recreios, festividades, entre outros.

Sobre o relacionamento pessoal e rotineiro com os alunos, os professores do CEF28 , procuram e são orientados a serem cautelosos, respeitosos e amigos, pois, a violência da região entra na escola e se manifesta sob a forma de ameaças de morte ou agressões, por parte de alunos que integram gangues que, porventura, se sintam ofendidos ou maltratados. 
Assim, pode se compreender as dificuldades reais que marcam o trabalho diário do professor do CEF-28 de Ceilândia, numa escola conhecida na região como lugar de violência e que por isso resulte em significativo rodízio de professores. Esses, ao chegarem e descobrirem os inúmeros problemas do cotidiano escolar, optam por não fazer parte do quadro efetivo de professores.

Por essas razões há enorme dificuldade em se construir um projeto político pedagógico coletivamente, e, até mesmo planos de ensino, pois, muitas vezes, os professores não se empenham, por não querer permanecer no local e aí estarem até o próximo concurso de remoção interna ou externa.

\subsection{Procedimentos de Construção das Informações Empíricas}

Os procedimentos para construção das informações empíricas utilizados nesta investigação foram questionários e entrevistas semiestruturadas, aplicados aos quatro professores do 6ำ ao 9o ano participantes da pesquisa. Além desses instrumentos, foi realizada a análise documental do PCN de Geografia (6ำ ao 9ำ Ano), o CM/EB-DF para a disciplina de Geografia, o PPP do CEF-28 e o PE dos professores de Geografia da Instituição.

\subsection{1- Os questionários e as entrevistas}

Os questionários foram elaborados com base nos objetivos específicos desta pesquisa e geraram as seguintes indagações:

a) Qual é o papel da Geografia na formação de seus alunos?

Esta pergunta buscou identificar a posição do professor sobre a importância do ensino de Geografia na formação dos alunos.

b) Que importância possui a Geografia para seus alunos?

Essa questão pretendeu verificar o nível de importância que o professor atribui a esta disciplina.

c) Que problemas você identifica nas relações de ensino/aprendizagem em Geografia? 
Objetiva-se identificar as dificuldades enfrentadas pelo professor nas relações de ensino/aprendizagem de seu cotidiano escolar, no CEF-28.

d) Como você insere o lugar de seus alunos no contexto de suas aulas?

Nesta questão pretendeu-se compreender como o lugar dos alunos é considerado nas aulas, no sentido de identificar se seu lugar de vivência se estabelece como parâmetro de comparação, para outros lugares não vividos.

e) O que você consulta para elaborar seu plano de ensino?

Esta indagação teve o propósito de obter informações referentes aos documentos que norteiam a prática dos professores do CEF-28 de Ceilândia-DF.

f) Quais destas atividades você utiliza em suas aulas?

Essa questão de múltipla escolha e também as questões (11, 12, 13 e 16 em anexo) teve o objetivo de verificar a prática pedagógica do professor. Nesse sentido, partiu-se do pressuposto que aulas onde prevalecem métodos tradicionais de ensino, filiam-se a uma concepção pedagógica liberal. E o contrário, a uma concepção progressista. Desse modo, no elenco de opções a serem assinaladas pelo professor, alternavam-se exemplos de práticas relacionadas a ambas as concepções.

g) Para você qual é o ponto mais importante na avaliação do aluno?

Esta pergunta buscou verificar se o professor, no processo de avaliação, opta pela compreensão ou memorização do conteúdo.

h) Você segue fielmente o livro didático?

Pretendeu-se verificar se o professor busca outros fundamentos que não o livro didático.

i) Você organiza aula de campo pelos setores onde os alunos moram?

Esta questão complementa aquela referente à consideração do lugar dos alunos. Nesse sentido, é importante ressaltar, que parte-se do pressuposto que trabalhos de campo constituem-se importantes elementos de construção de conceitos e significação à aprendizagem. Daí a importância de sua realização. 
j) Quais os instrumentos de avaliação você utiliza em sua rotina docente?

Questão complementar ao item f: pretendeu-se identificar a concepção pedagógica do professor em relação aos processos avaliativos de seus alunos.

As entrevistas foram realizadas dentro dos mesmos padrões dos questionários com base nos objetivos específicos desta pesquisa e foram utilizadas as questões dos itens ( $A$, $B, C, D, E$ e I) dos questionários. A opção de repetir as mesmas perguntas nas entrevistas, teve a intenção de colher elementos empíricos que não foram passíveis de serem auferidos por meio dos questionários.

Aproximadamente um mês após a aplicação dos questionários, foram realizadas as entrevistas com os professores de Geografia, na própria escola. Essas, individualizadas, duraram cerca de 30 minutos cada uma e foram feitas na sala do professor, onde foram gravadas para, posteriormente serem transcritas e sistematizadas.

\subsubsection{Análise Documental}

\subsubsection{A organização dos conteúdos de Geografia no PCN}

O PCN de Geografia o terceiro ciclo, que corresponde ao $6^{\circ}$ e $7^{\circ}$ ano do Ensino Fundamental, é dividido em quatro eixos temáticos, onde se inserem 10 temas e muitos conteúdos. Entre os eixos foram selecionados aqueles que desempenham um papel específico na formação para a cidadania e a valorização do lugar,

Nos eixos apontados para o terceiro e quarto ciclos encontram-se especificados 21 temas. Porém, para a presente análise, foram destacados somente aqueles que contribuem para a formação do aluno, na perspectiva do desenvolvimento de sua cidadania e valorização do lugar, conforme pode ser observado nos quadros 7 e 8 referente aos resultados.

Nessa etapa do processo ensino-aprendizagem, para a disciplina de Geografia, o tema e conteúdos proporcionam aos alunos entendimentos de como se constituem os espaços e lugares, bem como sua organização na sociedade capitalista. A compreensão de tal situação, então, apresenta o potencial de contribuir para que os alunos possam conquistar o seu espaço na sociedade e exercer, com responsabilidade, seus direitos e deveres de cidadãos. 
De acordo com os PCN's, o tema e conteúdos propostos para trabalhar cidadania e lugar, espera-se que os alunos façam um diálogo entre teoria e o seu espaço de vivência, na busca de perceber se os problemas sociais e ambientais integram a rotina de sua comunidade, além de terem a capacidade de apontar medidas que poderiam ser adotadas para minimizar ou excluir tais problemas.

Os PCN's de Geografia para o ensino fundamental para o quarto ciclo trazem proposta para o trabalho pedagógico que ampliem a percepção, compreensão e a valorização dos conteúdos de natureza mundial. No entanto, apreende-se que, o professor poderá ampliar os seus conteúdos para além do livro didático e dos PCN's para análise e comparação entre o mundo global e do lugar onde os alunos vivem.

A despeito dos PCN's do Ensino Fundamental terem sidos publicados em 1998 e com 17 anos após publicação, ainda é considerado um documento atual, por dispor de natureza aberta, com propostas flexíveis, passíveis de serem implementadas em consonância com as características regionais e a participação direta do professor.

\subsubsection{2 - Organização e objetivos apresentado no Currículo em Movimento da Educação Básica do Distrito Federal/CM/EB-DF para a disciplina de Geografia}

O Currículo em Movimento da Secretaria de Educação do Distrito Federal, elaborado com participação dos professores da rede pública de ensino, compreende a mesma natureza e similaridade dos PCN's, porém, não apresenta propostas flexíveis adequadas por anos que possibilita trabalhar a diversidade sociocultural da região. A partir dos referenciais norteadores encontrados no PCN de Geografia para o Ensino Fundamental, o Currículo em Movimento da Secretaria de Educação do Distrito Federal foi organizado em eixos transversais, no sentido de contemplar a Educação para a diversidade / Cidadania e Educação em e para os Direitos Humanos / Educação para a Sustentabilidade e, ainda, em eixos integradores, ludicidade e letramentos em Ciências Humanas.

Para $\circ 6^{\circ}$ ano apresenta os seguintes objetivos: compreender a importância da ciência geográfica e seus conceitos, desenvolvendo a interpretação da relação da sociedade com a natureza, questões ambientais e interação com seu espaço de vivência; localizar a Terra no universo; entender e utilizar a cartografia identificando suas técnicas de localização e de orientação; conhecer estrutura e dinâmica do planeta Terra. 
Para $07^{\circ}$ ano apresenta os seguintes objetivos: localizar e identificar o Brasil no Mundo; desenvolver conhecimento do espaço brasileiro, fatores que influenciam aspectos econômicos, políticos, sociais, culturais e ambientais, com ênfase nas diferenças regionais.

No 8ํano o CM/EB-DF apresenta objetivos e conteúdos orientados à compreensão do processo histórico de dependência econômico-político-cultural da América e da África na construção do mundo globalizado.

Do mesmo modo, no $9^{\circ}$ ano o CM/EB-DF apresenta objetivos e conteúdos voltados à compreensão do processo de desenvolvimento industrial, a revolução tecnológica e sua influência no mundo globalizado; conhecer e analisar aspectos físicos, ambientais, demográficos, políticos, sociais e econômicos da Europa, Ásia, Oceania e Antártida.

Durante o estudo deste documento pode-se compreender que as temáticas propostas e analisadas de cada ano apresentam possibilidades de serem consideradas para implementação de projetos pedagógicos que possam proporcionar a reflexão sobre semelhanças e diferenças vividas cotidianamente pelos alunos.

Para selecionar os dados do CM/EB-DF foi feita a leitura e análise do documento e em seguida foram elencados os conteúdos de Geografia pertinentes a cada ano e que possibilitassem o trabalho pedagógico embasados nas categorias Lugar e Cidadania. Assim, a partir desses dados, foi construído o quadro 9. Após a elaboração das tabelas procedeuse a comparação e análise dos dados.

\subsubsection{Projeto Político Pedagógico/PPP do Centro de Ensino Fundamental/CEF- 28 de Ceilândia}

E o PPP do CEF-28 de Ceilândia é um documento de 100 páginas e está dividido nos seguintes tópicos: Introdução, Origem Histórica, Natureza e Contexto da Instituição Educacional, Princípios Norteadores da Prática Educativa, Fundamentação / Princípios e Fins da Educação / Função da Escola, Missão e Objetivos Institucionais, Organização Pedagógica da Educação e dos Ensinos oferecidos, Normas Internas 2013 Referendadas pelo Conselho Escolar do CEF-28 de Ceilândia, Organização Curricular e Respectiva Matriz, Processo de Avaliação e Aprendizagem e das Execuções.

Este documento considera a escola como um espaço educativo, onde as ações não podem ser pensadas, nem realizadas no vazio e no inesperado. Ou seja, é necessário 
planejamento, para que a escola possa inovar sua prática pedagógica, na medida em que apresenta novos caminhos para as situações que devam ser modificadas.

Importante ressaltar, porém, que o PPP do CEF-28 ainda se encontra em processo de construção. Apesar de a escola possuir cinco anos de criação e funcionamento, a equipe ainda não conseguiu construir um PPP completo, que contemple propostas, objetivos e metas para todas as turmas e disciplinas do $6^{\circ}$ ao $9^{\circ}$ Ano. Nesse sentido, estão definidas, apenas, as questões relativas ao $2^{\circ}$ e $3^{\circ}$ anos. Os demais ainda não foram elaborados.

Durante o processo de coleta dos dados deste documento e em função da ausência dos conteúdos de Geografia do 6º ao 9a ano optou-se pela apresentação de quadros onde ficaram registrados os dados referentes a não existência desses conteúdos.

\subsubsection{4 - Plano de Ensino dos Professores de Geografia do CEF-28}

No contexto da análise documental, via de estruturação das informações empíricas subsidiares desta investigação, o Plano de Ensino dos Professores de Geografia do CEF-28 constitui-se importante elemento de pesquisa, por permitir a identificação das atividades realizadas no contexto das aulas, bem como compreender a lógica da prática de ensino realizada pelos professores, no dia a dia da escola. Nesse sentido, partiu-se do pressuposto que a identificação das intenções, objetivos e atividades a serem desenvolvidas no conjunto das aulas, possibilitariam inferir a conduta do professor, no sentido de evidenciar sua filiação às práticas tradicionais ou progressistas, por exemplo, entre outras questões.

Entretanto, para surpresa, constatou-se que os professores participantes desta pesquisa não elaboraram seus $\mathrm{PE}$, sob alegação de seu pouco tempo na instituição e, também, ausência de momentos de coordenação pedagógica, destinados a esse fim. Tal situação será considerada no item resultados e discussão.

No intuito de suprir essa lacuna de informação, buscou-se analisar o livro didático utilizado pelo professor.

\subsection{Procedimentos de Análise das Informações Empíricas}

Este tópico tem como objetivo explicitar os procedimentos de análise das informações empíricas desta pesquisa. Nesse sentido, optou-se por organizar tais 
informações em quadros, a partir das categorias Lugar e Cidadania, conforme pode ser identificado a seguir.

\subsubsection{Questionários}

Esta pesquisa incluiu a aplicação de questionários aos professores do CEF- 28 de Ceilândia com o objetivo de aprofundar na investigação referente ao papel da Geografia na formação, a identificação da importância da disciplina para os alunos e a inserção do lugar, aos problemas nas relações de ensino / aprendizagem, ao planejamento da aula, ao processo de avaliação, realização de trabalho de campo, da sua prática pedagógica, bem como das formas e materiais utilizados como base para o planejamento e execução de suas aulas.

As respostas coletadas foram organizadas em dois tópicos. No primeiro quadro apresentam-se as respostas individuais dos professores às questões propostas e no segundo quadro apresentam-se a síntese das respostas elencadas no primeiro quadro.

\subsubsection{Entrevistas}

Nesta pesquisa foram realizadas entrevistas com os professores, que foram gravadas, transcritas e sistematizadas em quadros, a partir das seguintes categorias: o papel e importância da Geografia; ensino aprendizagem; lugar e cidadania no trabalho pedagógico.

Posteriormente, as respostas das entrevistas, organizadas no quadro 15, foram comparadas com as respostas obtidas pelos questionários, no intuito de identificar e compreender as concepções pedagógicas de cada professor, bem como seus procedimentos metodológicos, notadamente, para inter-relacionar com as orientações estabelecidas pelos PCN's de Geografia, pelo CM/EB-DF e pelo Projeto Político Pedagógico da escola.

\subsubsection{Análise documental}

\subsubsection{PCN de Geografia}

Conforme já relatado elaborou-se um quadro identificando e explicitando os conteúdos da disciplina de Geografia e estabelecendo uma correlação entre conteúdo, 
categoria Lugar dentro de cada série (6ํㅜ ao $\left.9^{\circ}\right)$. Em seguida buscou-se correlacionar os conteúdos e o conceito de cidadania presente no PCN de Geografia.

Os PCN's apresentam o terceiro ciclo ( $6^{\circ}$ e $7^{\circ}$ ano) e o quarto ciclo ( $8^{\circ}$ e $\left.9^{\circ}\right)$ e organizam seus conteúdos em eixos. Os eixos são divididos em temas que por sua vez apresentam sugestões de sub temas para o trabalho em sala de aula. Nessa pesquisa, optou-se por selecionar entre os sub temas os conteúdos relacionados às categorias de pesquisa: Cidadania e Lugar.

\subsubsection{CM/EB-DF}

O CM/EB-DF apresenta de forma muita sintética os eixos integradores: Ludicidade e Letramentos / Ciências Humanas de Geografia, individualmente, para os 6ํㅜㄴ $7^{\circ} 8^{\circ}$ e $9^{\circ}$ anos e apresentam objetivos e conteúdos para cada série.

Assim, como procedimento metodológico, elaborou-se um quadro identificando e explicitando os conteúdos da disciplina de Geografia e estabelecendo uma correlação entre conteúdo, categoria Lugar e Cidadania dentro de cada série (6ํㅜ ao 9ํㅜ).

\subsubsection{PPP do CEF- 28 de Ceilândia}

Como procedimento de análise deste documento, elaborou-se um quadro identificando e explicitando os conteúdos da disciplina de Geografia e estabelecendo uma correlação entre conteúdos e categoria Lugar dentro de cada série. Em seguida buscou-se correlacioná-los ao conceito de cidadania presente no PPP do CEF-28 de Ceilândia para a disciplina de Geografia do 6ํㅜ ao 9․

Embora, não tenha sido possível coletar as informações neste documento conforme o estabelecido como procedimento metodológico, optou-se por elaborar o quadro para deixar registrado que nenhuma das informações foi encontrada no PPP do CEF-28 de Ceilândia.

\subsubsection{PE / LD}

A análise do PE seguiu o mesmo modo procedimental dos documentos anteriores. Elaborou-se um quadro identificando e explicitando os conteúdos da disciplina de Geografia e estabelecendo uma correlação entre conteúdo, categoria Lugar dentro de cada ano. Em 
seguida buscou-se correlacioná-los ao conceito de cidadania presente no PE dos professores do CEF-28 de Ceilândia para a disciplina de Geografia do 6ํㅜ ao 9ㅇ․

Devido a não existência desse documento optou-se por elaborar a tabela e deixar também registrado a não existência desse importante documento de planejamento.

Nessa perspectiva, optou-se por analisar os Livros Didáticos - LD, que foram escolhidos pelos professores, em virtude da importância dada pelos docentes, como currículo direcionador do trabalho pedagógico. 


\section{Capítulo III - Resultados da Pesquisa}

[...] Uma pesquisa pode nos levar a resultados mais ou menos claros e seguros, mas também nos pode levar a novos problemas, novas dúvidas e, naturalmente, a novas incertezas. Novas incertezas que motivarão novas pesquisas, nesse nosso destino de sempre estar descobrindo incertezas nas certezas alheias e tumulto onde outros só veem tranquilidade.

(PALACIOS, 2008, p. 1001).

\section{Resultados da Pesquisa}

Os resultados desta investigação, obtidos a partir da análise documental dos PCN's de Geografia para os anos finais do Ensino Fundamental, o CM/EB-DF, do PPP do CEF-28 de Ceilândia, o PE dos professores dessa escola, bem como a realização de entrevistas semiestruturadas e aplicação de questionários com aqueles professores, apresenta-se em forma de quadros. Nesse sentido, é importante esclarecer que toda a sistematização dessas informações foi efetuada com base nas categorias Lugar e Cidadania, conforme descrição no item 2.2. Assim, os itens que se seguem apresentam os quadros, resultado do processo de estruturação da base empírica desta pesquisa.

\subsection{Análise documental}

\subsubsection{PCN de Geografia}

Apresentam-se, a seguir, os quadros de análise dos conteúdos do PCN de Geografia inter-relacionados com a categoria Cidadania e Lugar.

\section{Quadro 7- Conteúdos do PCN de Geografia para trabalhar Cidadania}

\begin{tabular}{|l|l|l|l|}
\hline Categoria & Ciclos & \multicolumn{1}{|c|}{ Eixos } & \multicolumn{1}{c|}{ Conteúdos } \\
\hline Ciclo 3 & $\begin{array}{l}\text { A Geografia como uma } \\
\text { possibilidade de Leitura e } \\
\text { compreensão do mundo. }\end{array}$ & $\begin{array}{l}\text { As mudanças nas relaçães sociais } \\
\text { do trabalho e a separação entre } \\
\text { campo e a cidade; } \\
\text { O ambiente natural e as diferentes } \\
\text { formas de construção das moradias } \\
\text { no mundo; } \\
\text { A cidadania como a consciência de } \\
\text { pertencer, interagir e sentir integrado } \\
\text { com pessoas e lugares; } \\
\text { A segregação socioeconômica e } \\
\text { cultural como fator de exclusão } \\
\text { social e estímulo à criminalidade nas } \\
\text { cidades. }\end{array}$ \\
\hline
\end{tabular}




\begin{tabular}{|c|c|c|c|}
\hline \multirow{6}{*}{$\begin{array}{l}\text { C } \\
\text { I } \\
\text { D } \\
\text { A } \\
\text { D } \\
\text { A } \\
\text { N } \\
\text { I } \\
\text { A }\end{array}$} & & $\begin{array}{l}\text { O estudo da Natureza e } \\
\text { sua importância para o } \\
\text { homem. }\end{array}$ & $\begin{array}{l}\text { As cidades e as alterações } \\
\text { climáticas; } \\
\text { O lixo nas cidades: do consumismo } \\
\text { à poluição; } \\
\text { Modo de vida urbano e qualidade de } \\
\text { vida. }\end{array}$ \\
\hline & & $\begin{array}{l}\text { O campo e a cidade como } \\
\text { formações socioespaciais. }\end{array}$ & $\begin{array}{l}\text { As feiras livres como sobrevivência } \\
\text { do passado na moderna } \\
\text { urbanização; } \\
\text { Os sem tetos nas metrópoles e suas } \\
\text { relações com o processo de } \\
\text { modernização capitalista; } \\
\text { A sociabilidade entre as pessoas e } \\
\text { os grupos sociais no campo e na } \\
\text { cidade. }\end{array}$ \\
\hline & & $\begin{array}{lr}\text { A cartografia r como } \\
\text { instrumento na } \\
\text { aproximação dos lugares e } \\
\text { do mundo. }\end{array}$ & $\begin{array}{l}\text { Localização e representação das } \\
\text { posições na sala de aula, em casa, } \\
\text { no bairro e na cidade. }\end{array}$ \\
\hline & \multirow[t]{3}{*}{ Ciclo 4} & $\begin{array}{l}\text { A evolução das } \\
\text { tecnologias e as novas } \\
\text { territorialidades em redes. }\end{array}$ & $\begin{array}{l}\text { As políticas de transportes } \\
\text { metropolitanos: os transportes } \\
\text { coletivos, o metrô e o automóvel; } \\
\text { A internet, a comunicação } \\
\text { instantânea e simultânea e a } \\
\text { aproximação dos lugares; } \\
\text { A urbanização no período técnico- } \\
\text { científico informacional, a } \\
\begin{array}{l}\text { automação e o problema do } \\
\text { desemprego. }\end{array}\end{array}$ \\
\hline & & $\begin{array}{l}\text { Um só mundo e muitos } \\
\text { cenários geográficos. }\end{array}$ & $\begin{array}{l}\text { Os espaços das minorias nacionais, } \\
\text { étnicas e culturais; } \\
\text { Indicadores econômicos e sociais da } \\
\text { riqueza e do bem-estar e do } \\
\text { desenvolvimento humano; } \\
\text { Pobreza e exclusão social nos } \\
\text { países desenvolvidos } \\
\text { subdesenvolvidos; } \\
\text { O patrimônio cultural como fator de } \\
\text { integração latino-americano; } \\
\text { Formas de produção e relações de } \\
\text { trabalho no desenvolvimento } \\
\text { desigual do território; } \\
\text { As expressões culturais de origem } \\
\text { europeia, africana, indígena, asiática } \\
\text { e outras nas paisagens brasileiras; } \\
\text { Mobilidade da população } \\
\text { reprodução das desigualdades } \\
\text { socioespaciais nas cidades e no } \\
\text { campo. }\end{array}$ \\
\hline & & $\begin{array}{l}\text { Modernização, modos de } \\
\text { vida e a problemática }\end{array}$ & $\begin{array}{l}\text { As revoluções técnico-científicas, o } \\
\text { consumo de energia e outros }\end{array}$ \\
\hline
\end{tabular}




\begin{tabular}{|l|l|l|}
\hline ambiental. & recursos naturais e seus impactos \\
& no ambiente; \\
& Recursos naturais - esgotabilidade \\
e reversibilidade usar e recuperar; & Modo de vida urbano: consumo, \\
& lazer e hábitos urbanos; \\
Moradia urbana: habitações e \\
conforto urbano; \\
Ambiente urbano: água para todos; \\
O que é e para onde vai o lixo \\
urbano: tratamento e destino do lixo; \\
Saneamento básico: água e esgoto \\
e qualidade ambiental urbana; \\
Planejamento ambiental e políticas \\
publicas; \\
Conservação x preservação e \\
conflitos socioambientais; \\
Ecoturismo; \\
Urbanização e questão ambiental; \\
Soberania nacional e a legislação \\
ambiental brasileira.
\end{tabular}

Quadro 8 - Conteúdos do PCN de Geografia para trabalhar Lugar.

\begin{tabular}{|c|c|c|c|}
\hline Categoria & Ciclos & Eixos & Conteúdos \\
\hline \multirow{3}{*}{$\begin{array}{l}L \\
U \\
G \\
A \\
R\end{array}$} & \multirow[t]{3}{*}{ Ciclo 3} & $\begin{array}{l}\text { A Geografia como uma } \\
\text { possibilidade de Leitura e } \\
\text { compreensão do mundo. }\end{array}$ & $\begin{array}{l}\text { O ambiente natural e as diferentes } \\
\text { formas de construção das moradias no } \\
\text { mundo; } \\
\text { O lugar como a experiência vivida dos } \\
\text { homens com o território e paisagens; } \\
\text { O imaginário e as representações da } \\
\text { vida cotidiana; } \\
\text { O lugar como espaço vivido mediato e } \\
\text { imediato dos homens na interação } \\
\text { com o mundo; } \\
\text { A segregação socioeconômica e } \\
\text { cultural como fator de exclusão social } \\
\text { e estímulo à criminalidade nas } \\
\text { cidades. }\end{array}$ \\
\hline & & $\begin{array}{l}\text { O estudo da Natureza e } \\
\text { sua importância para o } \\
\text { homem. }\end{array}$ & $\begin{array}{l}\text { O clima no cotidiano das pessoas; } \\
\text { O lixo nas cidades: do consumismo à } \\
\text { poluição; } \\
\text { Áreas protegidas e espaços livres } \\
\text { urbanos. }\end{array}$ \\
\hline & & $\begin{array}{l}\text { O campo e a cidade } \\
\text { como formações } \\
\text { socioespaciais. }\end{array}$ & $\begin{array}{l}\text { As feiras livres como sobrevivência do } \\
\text { passado na moderna urbanização; } \\
\text { A sociabilidade entre as pessoas e os } \\
\text { grupos sociais no campo e na cidade. }\end{array}$ \\
\hline
\end{tabular}




\begin{tabular}{|c|c|c|}
\hline & $\begin{array}{lr}\text { A cartografia } & \text { como } \\
\text { instrumento } & \text { na } \\
\text { aproximação dos lugares } \\
\text { e do mundo. }\end{array}$ & $\begin{array}{l}\text { Orientações e mediações cartográfica; } \\
\text { Coordenadas geográficas. }\end{array}$ \\
\hline \multirow[t]{3}{*}{ Ciclo 4} & $\begin{array}{lr}\text { A evolução } & \text { das } \\
\text { tecnologias e as novas } \\
\text { territorialidades } \\
\text { redes. }\end{array}$ & $\begin{array}{l}\text { A internet, a comunicação instantânea } \\
\text { e simultânea e a aproximação dos } \\
\text { lugares. }\end{array}$ \\
\hline & $\begin{array}{l}\text { Um só mundo e muitos } \\
\text { cenários geográficos. }\end{array}$ & $\begin{array}{l}\text { Condicionantes naturais na } \\
\text { modelagem das paisagens brasileiras: } \\
\text { os processos interativos e a fisionomia } \\
\text { das paisagens; } \\
\text { Mobilidade da população e reprodução } \\
\text { das desigualdades socioespaciais nas } \\
\text { cidades e no campo. }\end{array}$ \\
\hline & $\begin{array}{l}\text { Modernização, modos de } \\
\text { vida e a problemática } \\
\text { ambiental. }\end{array}$ & $\begin{array}{l}\text { Recursos naturais - esgotabilidade e } \\
\text { reversibilidade usar e recuperar; } \\
\text { Modo de vida urbano: consumo, lazer } \\
\text { e hábitos urbanos; } \\
\text { Moradia urbana: habitações e conforto } \\
\text { urbano; } \\
\text { Ambiente urbano: água para todos; } \\
\text { O que é e para onde vai o lixo urbano: } \\
\text { tratamento e destino do lixo; } \\
\text { Espaços livres e paisagens urbanas: } \\
\text { áreas verdes nas cidades; } \\
\text { Ocupações de áreas de risco; } \\
\text { Saneamento básico: água e esgoto e } \\
\text { qualidade ambiental urbana; } \\
\text { Sistema de Áreas Protegidas; } \\
\text { Conservação x preservação e conflitos } \\
\text { socioambientais; } \\
\text { Ecoturismo; } \\
\text { Urbanização e questão ambiental; } \\
\text { Soberania nacional e a legislação } \\
\text { ambiental brasileira. }\end{array}$ \\
\hline
\end{tabular}

\subsubsection{CM/ED-DF}

Neste tópico, apresentam-se os conteúdos do documento CM/ED-DF para a disciplina Geografia, correlacionados com as categorias Cidadania e Lugar. 


\section{Quadro 9 - Conteúdos do CM/EB-DF da disciplina de Geografia para trabalhar Cidadania e Lugar.}

\begin{tabular}{|c|c|c|}
\hline Categoria & Anos & Conteúdos \\
\hline \multirow{4}{*}{$\begin{array}{l}C \\
I \\
D \\
A \\
D \\
A \\
N \\
I \\
A\end{array}$} & $6^{0}$ & $\begin{array}{l}\text { Relação do ser humano / Natureza /Sociedade; } \\
\text { O trabalho e a transformação do espaço geográfico; } \\
\text { Impactos Ambientais; } \\
\text { Preservação do meio ambiente; }\end{array}$ \\
\hline & $7^{0} \underline{0}$ & $\begin{array}{l}\text { Formação histórico-cultural do território brasileiro; } \\
\text { Análise do desenvolvimento sócio econômico brasileiro; } \\
\text { Características físicas e sócio econômico-culturais das regiões } \\
\text { brasileiras; } \\
\text { Processo e consequências da industrialização e modernização de } \\
\text { meios de produção e desigualdades sociais; } \\
\text { Migração da população: interna e externa; } \\
\text { Urbanização brasileira suas consequências, observando os } \\
\text { seguintes aspectos: emprego / desemprego, trabalho infantil, } \\
\text { direitos, e deveres de crianças e adolescente, moradia, } \\
\text { transporte, educação, segurança, saúde; } \\
\text { Meios de transporte e comunicações no Brasil - influências } \\
\text { sociais. }\end{array}$ \\
\hline & $8^{\circ}$ & $\begin{array}{l}\text { Diversidade étnica e social; } \\
\text { Cultura africana e influências no Brasil. }\end{array}$ \\
\hline & 9요 & Nenhum conteúdo que se refere a essa categoria. \\
\hline Categoria & Anos & Conteúdos \\
\hline \multirow{4}{*}{$\begin{array}{l}L \\
U \\
G \\
A \\
R\end{array}$} & $6^{\circ}$ & $\begin{array}{l}\text { O trabalho e a transformação do espaço geográfico; } \\
\text { Impactos Ambientais; } \\
\text { Preservação do meio ambiente; } \\
\text { Estudar o DF e o entorno destacando a Região Administrativa } \\
\text { (RA) de origem dos alunos. }\end{array}$ \\
\hline & $7^{0}$ & $\begin{array}{l}\text { Análise do desenvolvimento sócio econômico brasileiro; } \\
\text { Características físicas e sócio econômico-culturais das regiões } \\
\text { brasileiras; } \\
\text { Migração da população: interna e externa; } \\
\text { Urbanização brasileira suas consequências, observando os } \\
\text { seguintes aspectos: emprego / desemprego, trabalho infantil, } \\
\text { direitos, e deveres de crianças e adolescente, moradia, } \\
\text { transporte, educação, segurança, saúde; } \\
\text { Meios de transporte e comunicações no Brasil - influências } \\
\text { sociais. }\end{array}$ \\
\hline & $8^{\circ}$ & Nenhum conteúdo que se refere a essa categoria. \\
\hline & $9^{0}$ & Nenhum conteúdo que se refere a essa categoria. \\
\hline
\end{tabular}




\subsubsection{PPP}

Conforme já relatado, apresentam-se os dados do PPP, mesmo que inexistentes, em forma de quadro.

Quadro 10 - Conteúdos do PPP do CEF-28 de Ceilândia da disciplina de Geografia para trabalhar Cidadania e Lugar.

\begin{tabular}{|c|l|l|}
\hline Categoria & Anos & \multicolumn{1}{|c|}{ Conteúdos } \\
\hline C & $6^{\circ}$ & \\
I & $7^{\circ}$ & \\
D & $8^{\circ}$ & Nenhum conteúdo que se refere a essa \\
A & $9^{\circ}$ & categoria. \\
D & & \\
A & & \\
N & & \\
I & & \\
A & & \\
& $6^{\circ}$ & \\
L & $7^{\circ}$ & \\
U & $8^{\circ}$ & Nenhum conteúdo que se refere a essa \\
G & $9^{\circ}$ & categoria. \\
A & & \\
R & & \\
\hline
\end{tabular}

\subsubsection{PE}

Aqui se apresenta o quadro dos Planos de Ensino dos professores de Geografia do CEF-28 de Ceilândia, para demonstrar a proposta de metodologia de pesquisa. Em seguida demonstra-se a tabela de conteúdo do livro didático, conforme já explicitado nos procedimentos desta pesquisa.

Quadro 11 - Conteúdos do PE dos professores de Geografia do CEF-28 de Ceilândia para trabalhar Cidadania e Lugar

\begin{tabular}{|c|c|l|}
\hline Categoria & Anos & \multicolumn{2}{|c|}{ Conteúdos } \\
\hline C & & \\
I & & \\
D & $6^{\circ}$ & Nenhum conteúdo que se refere a essa \\
A & $7^{\circ}$ & categoria. \\
D & $8^{\circ}$ & \\
A & $9^{\circ}$ & \\
N & & \\
I & & \\
A & & \\
\hline
\end{tabular}




\begin{tabular}{|l|l|l|}
\hline$L$ & $6^{\circ}$ & \\
$U$ & $7^{\circ}$ & Nenhum conteúdo que se refere a essa \\
$G$ & $8^{\circ}$ & categoria. \\
$A$ & $9^{\circ}$ & \\
$R$ & & \\
\hline
\end{tabular}

\subsubsection{LD}

Como não foi possível analisar os PE dos professores de Geografia do CEF-28 de Ceilândia, buscou se identificar, nos Livros Didáticos - LD utilizados, algumas concepções que poderiam estar direta ou indiretamente relacionadas com esta pesquisa. Pesa nessa decisão o fato do livro didático ser, ainda, o principal elemento de construção da aprendizagem.

Desse modo, serão destacadas as orientações dos livros didáticos, referentes aos procedimentos atitudinais, estes incluem normas, valores, e atitudes que permeiam todo o conhecimento escolar, esperados para o alcance dos objetivos da aprendizagem.

\section{Quadro 12 - Cidadania e Lugar nos LD escolhidos pelos professores de Geografia do CEF-28 de Ceilândia}

\begin{tabular}{|c|c|c|}
\hline Categoria & Anos & Conteúdos \\
\hline \multirow{2}{*}{$\begin{array}{c}C \\
I \\
D \\
A \\
D \\
A \\
N \\
I \\
A\end{array}$} & $6^{\circ}$ & $\begin{array}{l}\text { A ação humana e a organização do espaço geográfico; } \\
\text { Associação das estações do ano com as atividades humanas } \\
\text { desenvolvidas nos lugares; } \\
\text { Os agentes modeladores da paisagem, tanto os naturais como os } \\
\text { decorrentes da ação humana; } \\
\text { Os recursos naturais necessários aos interesses dos seres } \\
\text { humanos; } \\
\text { Reflorestamento e melhoria do ar atmosférico; } \\
\text { As ações orientadas à superação dos problemas de desequilíbrio } \\
\text { ambiental, bem como as ações voltadas à preservação, } \\
\text { conservação, recuperacão do meio. }\end{array}$ \\
\hline & $7^{\circ}$ & $\begin{array}{l}\text { A diversidade étnica e cultural presente no território brasileiro; } \\
\text { Os fatores constitutivos das metrópoles; } \\
\text { As particularidades que distinguem as cidades dentro do espaço } \\
\text { urbano; } \\
\text { Os problemas urbanos mais significativos das regiões } \\
\text { metropolitanas e das cidades; } \\
\text { O processo de distribuição de terras em relação aos movimentos } \\
\text { sociais; } \\
\text { As diversas paisagens, resultado da relação entre os elementos } \\
\text { naturais e a ação humana; } \\
\text { A interferência da ação humana na natureza e suas } \\
\text { consequências em relação ao futuro; }\end{array}$ \\
\hline
\end{tabular}




\begin{tabular}{|c|c|c|}
\hline & & $\begin{array}{l}\text { Os principais problemas socioambientais relacionados às } \\
\text { atividades humanas no território brasileiro. }\end{array}$ \\
\hline & $8^{0}$ & $\begin{array}{l}\text { Os elementos que contribuem para a construção de uma } \\
\text { identidade nacional; } \\
\text { A língua e a religião como elementos culturais importantes na } \\
\text { identidade de uma nação; } \\
\text { O crescimento urbano e os problemas sociais gerados pela falta } \\
\text { de infraestrutura nas cidades; } \\
\text { A migração para as cidades e os processos de urbanização e } \\
\text { metropolização; } \\
\text { O desenvolvimento econômico, crescimento urbano e à formação } \\
\text { de metrópoles. }\end{array}$ \\
\hline & 9음 & $\begin{array}{l}\text { A importância da internet e das redes sociais para a divulgação } \\
\text { mundial dos acontecimentos locais e suas consequências sociais; } \\
\text { A importância da internet como meio de conexão e } \\
\text { compartilhamento de informações; } \\
\text { Os desafios dos países pobres ou em desenvolvimento para } \\
\text { eliminar as desigualdades sociais e elevar a qualidade de vida da } \\
\text { população. }\end{array}$ \\
\hline Categoria & Anos & \\
\hline \multirow[t]{3}{*}{$\begin{array}{l}L \\
U \\
G \\
A \\
R\end{array}$} & $6^{\circ}$ & $\begin{array}{l}\text { Identificação de elementos naturais e culturais da paisagem; } \\
\text { Comparação de paisagens e identificação de diferenças e } \\
\text { semelhanças, bem como suas transformações ao longo do } \\
\text { tempo; } \\
\text { Elaboração de hipóteses sobre a organização dos lugares; } \\
\text { Relação de determinados elementos da paisagem com a história } \\
\text { dos lugares; } \\
\text { A ação humana na paisagem, por meio das diferenças entre } \\
\text { modos de vida; } \\
\text { Associação das estações do ano com as atividades humanas } \\
\text { desenvolvidas nos lugares; } \\
\text { Os recursos naturais necessários aos interesses dos seres } \\
\text { humanos; } \\
\text { As ações orientadas à superação dos problemas de desequilíbrio } \\
\text { ambiental, bem como as ações voltadas à preservação, } \\
\text { conservação, recuperação do meio. }\end{array}$ \\
\hline & $7^{0}$ & $\begin{array}{l}\text { As particularidades que distinguem as cidades dentro do espaço } \\
\text { urbano; Os problemas urbanos mais significativos das regiões } \\
\text { metropolitanas e das cidades; } \\
\text { O processo de distribuição de terras em relação aos movimentos } \\
\text { sociais; } \\
\text { A interferência da ação humana na natureza e suas } \\
\text { consequências em relação ao futuro; } \\
\text { Os principais problemas socioambientais relacionados às } \\
\text { atividades humanas no território brasileiro; } \\
\text { O conceito de Unidades de Conservação Ambiental; } \\
\text { O processo de crescimento urbano. }\end{array}$ \\
\hline & $8^{\circ}$ & $\begin{array}{l}\text { Os conceitos de territorialidade, nação, território e Estado; } \\
\text { O crescimento urbano e os problemas sociais gerados pela falta } \\
\text { de infraestrutura nas cidades; } \\
\text { A migração para as cidades e os processos de urbanização e } \\
\text { metropolização; }\end{array}$ \\
\hline
\end{tabular}




\begin{tabular}{|l|l|l|}
\hline & $\begin{array}{l}\text { O desenvolvimento econômico, o crescimento urbano e à } \\
\text { formação de metrópoles. }\end{array}$ \\
\cline { 2 - 3 } & $\begin{array}{l}\text { A importância da internet e das redes sociais para a divulgação } \\
\text { mundial dos acontecimentos locais e suas consequências sociais. }\end{array}$ \\
\hline
\end{tabular}

\subsection{Organização das Respostas e Quadro Síntese dos Questionários}

Nesta etapa da pesquisa, apresentam se os quadros sínteses dos questionários respondidos pelos professores de Geografia do CEF- 28 de Ceilândia.

\section{Quadro 13 - Respostas dos professores por grupo de perguntas}

\begin{tabular}{|c|c|}
\hline \multicolumn{2}{|r|}{ O papel da Geografia na formação dos alunos. } \\
\hline Professor 1 & $\begin{array}{l}\text { O papel da Geografia é preparar os alunos para o } \\
\text { profissionalismo e para o mercado de trabalho, isto é, futuros } \\
\text { profissionais. }\end{array}$ \\
\hline Professor 2 & $\begin{array}{l}\text { Compreender, analisar, identificar e explicar os fenômenos } \\
\text { naturais, sociais, econômicos e culturais em escalas local e } \\
\text { global. }\end{array}$ \\
\hline Professor 3 & $\begin{array}{l}\text { Incitar nos alunos pensamentos críticos sobre a sociedade em } \\
\text { que vivem. }\end{array}$ \\
\hline Professor 4 & $\begin{array}{l}\text { Conectar as diversas realidades à realidade dos alunos de forma } \\
\text { a ensina-los a interpretar e compreender o que estudam. }\end{array}$ \\
\hline \multicolumn{2}{|r|}{ A importância da Geografia para seus alunos. } \\
\hline Professor 1 & $\begin{array}{l}\text { A importância é que meus alunos vão ter noções de tudo que fala } \\
\text { sobre a Terra, a população, agricultura meio de transporte } \\
\text { trabalho, etc. }\end{array}$ \\
\hline Professor 2 & $\begin{array}{l}\text { Nesta, o professor respondeu que essa pergunta poderia ser feita } \\
\text { aos alunos. }\end{array}$ \\
\hline Professor 3 & $\begin{array}{l}\text { Apresentar aos alunos informações para que eles possam ler e } \\
\text { interpretar as relações sociedade/natureza de forma crítica. }\end{array}$ \\
\hline Professor 4 & $\begin{array}{l}\text { E tratada como submatéria, sendo que outras disciplinas são } \\
\text { priorizadas. Venho observando algumas pequenas mudanças na } \\
\text { seriedade com que encaram a disciplina. }\end{array}$ \\
\hline \multicolumn{2}{|c|}{ A inserção do lugar de seus alunos no contexto de suas aulas. } \\
\hline Professor 1 & $\begin{array}{l}\text { O ambiente é propício para as aulas a serem dados, o problema } \\
\text { não é o local, mas sim a falta de recursos didáticos. }\end{array}$ \\
\hline Professor 2 & $\begin{array}{l}\text { Trabalhando a realidade socioeconômica deles com os } \\
\text { conteúdos ministrados. }\end{array}$ \\
\hline Professor 3 & Utilizando exemplos relacionados ao conteúdo trabalhado. \\
\hline Professor 4 & $\begin{array}{l}\text { Faço contrapontos dos conteúdos estudados com o local em que } \\
\text { os meninos moram. }\end{array}$ \\
\hline \multicolumn{2}{|c|}{$\begin{array}{c}\text { Problemas identificados pelos professores nas relações de } \\
\text { ensino/aprendizagem em Geografia. }\end{array}$} \\
\hline Professor 1 & $\begin{array}{l}\text { Inexistência de material didático específico (mapas, globos, } \\
\text { bússolas); } \\
\text { Falta de recursos didáticos. }\end{array}$ \\
\hline
\end{tabular}




\begin{tabular}{|c|c|}
\hline Professor 2 & $\begin{array}{l}\text { Infraestrutura precária da escola; } \\
\text { Inexistência de material didático específico (mapas, globos, } \\
\text { bússolas); } \\
\text { Inexistência de laboratório; } \\
\text { Laboratório de informática inadequado ao uso; } \\
\text { Alunos carentes; } \\
\text { Gestão ineficiente. }\end{array}$ \\
\hline Professor 3 & $\begin{array}{l}\text { Alunos carentes; } \\
\text { Desinteresse dos alunos pela escola. }\end{array}$ \\
\hline Professor 4 & $\begin{array}{l}\text { Alunos carentes; } \\
\text { Gestão ineficiente; } \\
\text { Falta de interesse dos alunos e de incentivos externo (família) } \\
\text { para que os alunos estudem. }\end{array}$ \\
\hline \multicolumn{2}{|r|}{ Material consultado na elaborar do plano de ensino. } \\
\hline Professor 1 & $\begin{array}{l}\text { Projeto Político Pedagógico CEF-28 de Ceilândia; } \\
\text { Livro didático. }\end{array}$ \\
\hline Professor 2 & $\begin{array}{l}\text { Diretrizes Curriculares Nacionais; } \\
\text { Parâmetros Curriculares de Geografia; } \\
\text { Currículo em movimento da Educação Básica; } \\
\text { Projeto Político Pedagógico CEF-28 de Ceilândia; } \\
\text { Livro didático. }\end{array}$ \\
\hline Professor 3 & $\begin{array}{l}\text { Currículo em movimento da Educação Básica; } \\
\text { Livro didático. }\end{array}$ \\
\hline Professor 4 & $\begin{array}{l}\text { Parâmetros Curriculares de Geografia; } \\
\text { Currículo em movimento da Educação Básica; } \\
\text { Livro didático. }\end{array}$ \\
\hline \multicolumn{2}{|r|}{ Atividades utilizadas pelos professores em suas aulas. } \\
\hline Professor 1 & $\begin{array}{l}\text { Exercício no livro didático; } \\
\text { Leitura no livro didático; } \\
\text { Questionários; } \\
\text { Análises de filmes; } \\
\text { Atividade em grupo; } \\
\text { Atividades individuais; } \\
\text { Análises de mapas; } \\
\text { Produção de textos; } \\
\text { Cópias; } \\
\text { Construção de legendas; } \\
\text { Construção de gráficos; } \\
\text { Cópias de mapas; } \\
\text { Análises de gráficos. }\end{array}$ \\
\hline Professor 2 & $\begin{array}{l}\text { Exercício no livro didático; } \\
\text { Leitura no livro didático; } \\
\text { Arguições; } \\
\text { Questionários; } \\
\text { Análises de músicas; } \\
\text { Análises de filmes; } \\
\text { Atividade em grupo; } \\
\text { Atividades individuais; } \\
\text { Análises de mapas; } \\
\text { Produção de textos; } \\
\text { Análises de gráficos. }\end{array}$ \\
\hline Professor 3 & Exercício no livro didático; \\
\hline
\end{tabular}




\begin{tabular}{|c|c|}
\hline & $\begin{array}{l}\text { Leitura no livro didático; } \\
\text { Questionários; } \\
\text { Análises de músicas; } \\
\text { Atividade em grupo; } \\
\text { Atividades individuais; } \\
\text { Análises de mapas; } \\
\text { Cópias; } \\
\text { Construção de gráficos; } \\
\text { Cópias de mapas; } \\
\text { Análises de gráficos. }\end{array}$ \\
\hline Professor 4 & $\begin{array}{l}\text { Exercício no livro didático; } \\
\text { Arguições; } \\
\text { Atividade em grupo; } \\
\text { Atividades individuais; } \\
\text { Análises de mapas; } \\
\text { Cópias. }\end{array}$ \\
\hline \multicolumn{2}{|c|}{$\begin{array}{c}\text { Pontos mais importantes considerados pelos professores na avaliação do } \\
\text { aluno. }\end{array}$} \\
\hline Professor 1 & $\begin{array}{l}\text { Compreensão do conteúdo; } \\
\text { Compreensão do texto do livro didático. }\end{array}$ \\
\hline Professor 2 & Compreensão do conteúdo; \\
\hline Professor 3 & $\begin{array}{l}\text { Memorização do conteúdo; } \\
\text { Compreensão do conteúdo; }\end{array}$ \\
\hline Professor 4 & Compreensão do conteúdo; \\
\hline \multicolumn{2}{|r|}{ Segue fielmente o livro didático? } \\
\hline Professor 1 & Em parte \\
\hline Professor 2 & Em parte \\
\hline Professor 3 & Em parte \\
\hline Professor 4 & Não \\
\hline \multicolumn{2}{|c|}{ Realização de aulas de campo pelos setores onde os alunos moram. } \\
\hline Professor 1 & Não \\
\hline Professor 2 & Não \\
\hline Professor 3 & Não \\
\hline Professor 4 & Não \\
\hline \multicolumn{2}{|c|}{ Instrumentos de avaliação utilizados na rotina docente. } \\
\hline Professor 1 & $\begin{array}{l}\text { Provas objetivas; } \\
\text { Provas subjetivas; } \\
\text { Trabalhos em grupos; } \\
\text { Relatórios; } \\
\text { Trabalhos extraclasse e pesquisa. }\end{array}$ \\
\hline Professor 2 & $\begin{array}{l}\text { Provas objetivas; } \\
\text { Provas subjetivas; } \\
\text { Arguições orais; } \\
\text { Trabalhos em grupos; } \\
\text { Relatórios. }\end{array}$ \\
\hline Professor 3 & $\begin{array}{l}\text { Provas objetivas; } \\
\text { Provas subjetivas; } \\
\text { Trabalhos em grupos; }\end{array}$ \\
\hline Professor 4 & $\begin{array}{l}\text { Provas objetivas; } \\
\text { Provas subjetivas; } \\
\text { Trabalhos em grupos; } \\
\text { Relatórios. }\end{array}$ \\
\hline
\end{tabular}


O quadro que se segue, elaborado a partir do anterior, representa a síntese do pensamento dos professores pesquisados do CEF-28 de Ceilândia.

\section{Quadro 14 - Síntese dos questionários}

\begin{tabular}{|c|c|}
\hline Perguntas & Síntese das respostas \\
\hline $\begin{array}{l}\text { Qual é o papel da Geografia na formação } \\
\text { de seus alunos? }\end{array}$ & $\begin{array}{l}\text { - O papel da Geografia é preparar os } \\
\text { alunos para o profissionalismo e para o } \\
\text { mercado de trabalho, isto é, futuros } \\
\text { profissionais; } \\
\text { - Compreender, analisar, identificar e } \\
\text { explicar os fenômenos naturais, sociais, } \\
\text { econômicos e culturais em escalas local } \\
\text { e global. } \\
\text { - Incitar nos alunos pensamentos críticos } \\
\text { sobre a sociedade em que vivem; } \\
\text { - Conectar as diversas realidades à } \\
\text { realidade dos alunos de forma a ensina- } \\
\text { los a interpretar e compreender o que } \\
\text { estudam. }\end{array}$ \\
\hline $\begin{array}{l}\text { Que importância possui a Geografia para } \\
\text { seus alunos? }\end{array}$ & $\begin{array}{l}\text { - A importância é que meus alunos vão } \\
\text { ter noções de tudo que fala sobre a } \\
\text { Terra, a população, agricultura meios de } \\
\text { transporte, trabalho, etc; } \\
\text { - Apresentar aos alunos informações para } \\
\text { que eles possam ler e interpretar as } \\
\text { relações sociedade/natureza de forma } \\
\text { crítica; } \\
\text { - E tratada como submatéria, sendo que } \\
\text { outras disciplinas são priorizadas. Venho } \\
\text { observando algumas pequenas } \\
\text { mudanças na seriedade com que } \\
\text { encaram a disciplina. }\end{array}$ \\
\hline $\begin{array}{l}\text { Como você insere o lugar de seus alunos } \\
\text { no contexto de suas aulas? }\end{array}$ & $\begin{array}{l}\text { - O ambiente é propício para as aulas a } \\
\text { serem dados, o problema não é o local, } \\
\text { mas sim a falta de recursos didáticos; } \\
\text { - Trabalhando a realidade } \\
\text { socioeconômica deles com os conteúdos } \\
\text { ministrados; } \\
\text { - Utilizando exemplos relacionados ao } \\
\text { conteúdo trabalhado; } \\
\text { - Faço contrapontos dos conteúdos } \\
\text { estudados com o local em que os } \\
\text { meninos moram. }\end{array}$ \\
\hline $\begin{array}{l}\text { Que problemas você identifica nas } \\
\text { relações de ensino/aprendizagem em } \\
\text { Geografia? }\end{array}$ & $\begin{array}{l}\text { - Inexistência de material didático } \\
\text { específico (mapas, globos, bússolas); } \\
\text { - Falta de recursos didáticos; } \\
\text { - Infraestrutura precária da escola; } \\
\text { - Inexistência de laboratório; } \\
\text { - Laboratório de informática inadequado } \\
\text { ao uso; }\end{array}$ \\
\hline
\end{tabular}




\begin{tabular}{|c|c|}
\hline & $\begin{array}{l}\text { - Alunos carentes; } \\
\text { - Gestão ineficiente; } \\
\text { - Falta de interesse dos alunos e de } \\
\text { incentivos externo (família) para que os } \\
\text { alunos estudem. }\end{array}$ \\
\hline $\begin{array}{l}\text { O que você consulta para elaborar seu } \\
\text { plano de ensino? }\end{array}$ & $\begin{array}{l}\text { - Diretrizes Curriculares Nacionais; } \\
\text { - Parâmetros Curriculares de Geografia; } \\
\text { - Currículo em movimento da Educação } \\
\text { Básica; } \\
\text { - Projeto Político Pedagógico CEF-28 de } \\
\text { Ceilândia; } \\
\text { - Livro didático. }\end{array}$ \\
\hline $\begin{array}{l}\text { Quais destas atividades você utiliza em } \\
\text { suas aulas? }\end{array}$ & $\begin{array}{l}\text { - Exercício no livro didático; } \\
\text { - Leitura no livro didático; } \\
\text { - Questionários; } \\
\text { - Análises de filmes; } \\
\text { - Atividade em grupo; } \\
\text { - Atividades individuais; } \\
\text { - Análises de mapas; } \\
\text { - Produção de textos; } \\
\text { - Cópias; } \\
\text { - Construção de legendas; } \\
\text { - Construção de gráficos; } \\
\text { - Cópias de mapas; } \\
\text { - Análises de gráficos; } \\
\text { - Arguições; } \\
\text { - Análises de músicas; }\end{array}$ \\
\hline $\begin{array}{l}\text { Para você qual é o ponto mais importante } \\
\text { na avaliação do aluno? }\end{array}$ & $\begin{array}{l}\text { - Compreensão do conteúdo; } \\
\text { - Compreensão do texto do livro didático; } \\
\text { - Memorização do conteúdo. }\end{array}$ \\
\hline Você segue fielmente o livro didático? & $\begin{array}{l}\text { - Em parte; } \\
\text { - Não. }\end{array}$ \\
\hline $\begin{array}{l}\text { Você organiza aula de campo pelos } \\
\text { setores onde os alunos moram? }\end{array}$ & - Não. \\
\hline $\begin{array}{l}\text { Quais são os instrumentos de avaliação } \\
\text { abaixo você utiliza em sua rotina } \\
\text { docente? }\end{array}$ & $\begin{array}{l}\text { - Provas objetivas; } \\
\text { - Provas subjetivas; } \\
\text { - Trabalhos em grupos; } \\
\text { - Relatórios; } \\
\text { - Trabalhos extraclasse e pesquisa; } \\
\text { - Arguições orais; }\end{array}$ \\
\hline
\end{tabular}

\subsection{Sistematização e Quadro Síntese das Entrevistas}

O quadro que se segue representa as respostas dos professores por grupo de perguntas das entrevistas. 


\section{Quadro 15 - Respostas dos professores por grupo de perguntas}

\begin{tabular}{|c|c|}
\hline \multicolumn{2}{|r|}{ O papel da Geografia na formação de seus alunos } \\
\hline Professor 1 & Preparar os alunos para o mercado de trabalho \\
\hline Professor 2 & $\begin{array}{l}\text { Tentar situá-los quanto os aspectos físicos, humanos, sociais, } \\
\text { econômicos e culturais. }\end{array}$ \\
\hline Professor 3 & $\begin{array}{l}\text { ldentificar o mundo em que vive e saber perceber as relações que } \\
\text { existem dentro dele, para compreender as relações em que estão } \\
\text { inseridos. }\end{array}$ \\
\hline Professor 4 & Trazer o que está fora da realidade deles pra realidade. \\
\hline \multicolumn{2}{|r|}{ Importância da Geografia para os seus alunos } \\
\hline Professor 1 & Conhecimento de tudo. \\
\hline Professor 2 & $\begin{array}{l}\text { Perceber que a Geografia vai ajudá-los socialmente; vai ajudá-los na } \\
\text { questão política, na questão social, na questão econômica, para o } \\
\text { entendimento; identificar problemas e encontrar soluções. }\end{array}$ \\
\hline Professor 3 & $\begin{array}{l}\text { Inserir o aluno no mundo crítico, que os mesmos percebam a relação } \\
\text { sociedade-natureza para construir um mundo melhor. }\end{array}$ \\
\hline Professor 4 & $\begin{array}{l}\text { Formar pessoas com olhar críticas para os acontecimentos } \\
\text { contemporâneos e que sejam capazes de contribuir para as melhorias. }\end{array}$ \\
\hline \multicolumn{2}{|c|}{ Problemas identificados nas relações de ensino-aprendizagem } \\
\hline Professor 1 & Falta material didático. \\
\hline Professor 2 & $\begin{array}{l}\text { Falta de infraestrutura e estrutura precária nas escolas, inexistência de } \\
\text { alguns materiais didáticos, ausência de laboratório de informática, falta } \\
\text { de apoio da família, gestão ineficiente. }\end{array}$ \\
\hline Professor 3 & ociar a importância dessa disciplina para o seu di \\
\hline Profes: & Desinteresse dos alunos, ausência de material didático. \\
\hline \multicolumn{2}{|r|}{ A inserção do lugar dos alunos no contexto das aulas } \\
\hline Professor 1 & O espaço insuficiente para realizar um trabalho. \\
\hline Professor 2 & o que eles vivenciam na prática. \\
\hline Professor 3 & Comparação entre conteúdo do livro com o lugar de vivência. \\
\hline Professor 4 & $\begin{array}{l}\text { Comparar a realidade deles com a realidade desses países que a gente } \\
\text { está estudando. }\end{array}$ \\
\hline \multicolumn{2}{|r|}{ Material consultado para elaborar o plano de ensino. } \\
\hline Professor 1 & Livros, internet, Jornais, revistas e vídeos. \\
\hline Professor 2 & $\begin{array}{l}\text { Parâmetros Curriculares da Geografia, Currículo em Movimento da } \\
\text { Educação Básica, o PPP da escola, o livro didático, revistas, periódicos. }\end{array}$ \\
\hline Professor 3 & Livro didático, Currículo em Movimento e as Diretrizes Curriculares. \\
\hline Professor 4 & Livro didático, PPP da escola, os PCN's. \\
\hline \multicolumn{2}{|c|}{ Realização de aula de campo pelos setores onde os seus alunos moram. } \\
\hline Professor 1 & Não. \\
\hline Professor 2 & Não. \\
\hline Professor 3 & Não. \\
\hline Professor 4 & \\
\hline
\end{tabular}

O quadro que se segue, elaborado a partir do anterior, representa a síntese do pensamento de cada professor. 


\section{Quadro 16 - Posição dos professores.}

\begin{tabular}{|c|c|}
\hline Professor 1 & $\begin{array}{l}\text { O papel da Geografia é preparar os alunos para o mercado de trabalho; } \\
\text { A importância da Geografia é fornecer uma visão geral do mundo; } \\
\text { Os problemas nas relações de ensino/aprendizagem relacionam-se à } \\
\text { falta de material didático; } \\
\text { Os espaços do lugar dos alunos são insuficientes para realizar um } \\
\text { trabalho; } \\
\text { Os materiais consultados para elaborar as aulas são: livros, internet, } \\
\text { Jornais, revistas e vídeos; } \\
\text { Não realiza aulas de campos pelos setores de seus alunos. }\end{array}$ \\
\hline Professor 2 & $\begin{array}{l}\text { O papel da geografia é tentar situar os alunos quanto os aspectos físicos, } \\
\text { humanos, sociais, econômicos e culturais; } \\
\text { A importância da Geografia é ajudar os alunos socialmente; vai ajuda-los } \\
\text { nas questões políticas, sociais, econômicas, na busca do entendimento } \\
\text { para identificar problemas e encontrar soluções; } \\
\text { Os problemas nas relações de ensino/aprendizagem são devidos os } \\
\text { espaços do lugar dos alunos e a falta de infraestrutura e estruturas } \\
\text { precária nas escolas, inexistência de alguns materiais didáticos, } \\
\text { ausência de laboratório de informática, falta de apoio da família, gestão } \\
\text { ineficiente; } \\
\text { A inserção do lugar dos alunos acontece com aulas teóricas e } \\
\text { relacionando o que eles vivenciam na prática; } \\
\text { Os materiais consultados para elaborar as aulas são: Parâmetros } \\
\text { Curriculares da Geografia, Currículo em Movimento da Educação Básica, } \\
\text { o PPP da escola, o livro didático, revistas, periódicos; } \\
\text { Não realiza aulas de campos pelos setores de seus alunos. }\end{array}$ \\
\hline Professor 3 & $\begin{array}{l}\text { O papel da geografia é identificar o mundo em que vive e saber perceber } \\
\text { as relações que existem dentro dele, para compreender as relações em } \\
\text { que estão inseridos; } \\
\text { A importância da Geografia é inserir o aluno no mundo crítico, que os } \\
\text { mesmos percebam a relação sociedade-natureza para construir um } \\
\text { mundo melhor; } \\
\text { Os problemas nas relações de ensino/aprendizagem são os alunos não } \\
\text { associarem a importância dessa disciplina para o seu dia-a-dia; } \\
\text { A inserção do lugar dos alunos acontece na comparação entre conteúdo } \\
\text { do livro com o lugar de vivência; } \\
\text { Os materiais consultados para elaborar as aulas são: livro didático, } \\
\text { Currículo em Movimento e as Diretrizes Curriculares; } \\
\text { Não realiza aulas de campos pelos setores de seus alunos. }\end{array}$ \\
\hline Professor 4 & $\begin{array}{l}\text { O papel da geografia é trazer o que está fora da realidade deles pra } \\
\text { realidade; } \\
\text { A importância da Geografia é formar pessoas com olhar críticas para os } \\
\text { acontecimentos contemporâneos e que sejam capazes de contribuir para } \\
\text { as melhorias; } \\
\text { Os problemas nas relações de ensino/aprendizagem são desinteresse } \\
\text { dos alunos, ausência de material didático; } \\
\text { A inserção do lugar dos alunos acontece ao comparar a realidade deles } \\
\text { com a realidade desses países que a gente está estudando; } \\
\text { Os materiais consultados para elaborar as aulas são: livro didático, PPP } \\
\text { da escola, os PCN's; } \\
\text { Não realiza aulas de campos pelos setores de seus alunos. }\end{array}$ \\
\hline
\end{tabular}




\section{Capítulo IV - Discussão dos Resultados}

"O sentido que têm as coisas, isto é, seu verdadeiro valor, é o fundamento da correta interpretação de tudo o que existe." (SANTOS, 2000).

\section{Discussão dos Resultados}

Neste capítulo serão apresentadas as reflexões sobre os resultados da pesquisa empírica. Optou se por analisar informação separadamente, no sentido de se obter maior clareza, evidenciar os pontos comuns, convergentes e divergentes.

\subsection{Questionários}

Analisando as respostas dadas pelos professores aos questionários, verificou-se uma expressiva heterogeneidade nas concepções pedagógicas e políticas de cada um. Nesse sentido, é reforçado o papel da coordenação pedagógica da escola, em promover oportunidades de planejamento coletivo e de formação continuada, para minimizar diferenças que podem por em risco a opção por um trabalho pedagógico integrado. Não é à toa que a própria SEE-DF por meio CM/EB-DF, propõe que o currículo seja vivenciado e reconstruído no cotidiano escolar, no intuito de que a organização do trabalho pedagógico da escola seja possível.

Há de se ressaltar, porém, que a situação enfrentada em muitas das escolas da rede pública não contribui para que ocorram momentos de coordenação pedagógica. Nesse sentido, o CEF-28 de Ceilândia sofreu com a troca do Supervisor Pedagógico: foram (seis) em quatro anos. Somente em 2012, a escola conseguiu contar com um profissional que foi lotada nesta escola. Essa situação coincidiu com o momento em que a SEE-DF realizou reuniões com os vários Supervisores Pedagógicos, para estudarem as propostas do Currículo em Movimento e orientar a organização do PPP das escolas. Além disso, é pertinente comentar, que em algumas escolas do DF e entre essas o CEF-28 de Ceilândia, houve grande resistência dos professores, do 6ำ ao 9ำ ano, ao novo currículo, que propunha a organização em Ciclos de Desenvolvimento Humano. Essa resistência se mostrou por meio de tumultos nas reuniões pedagógicas das escolas, protestos nas redes sociais e até denúncias ao Ministério Público e nesse contexto é que se deu o início da elaboração do atual PPP e que culminou com a saída da Supervisora Pedagógica. Portanto, é até compreensível que tal documento não contemple todos os anos do Ensino Fundamental. Assim, desmantelou-se no CEF-28 de Ceilândia, o trabalho pedagógico coletivo que estava sendo realizado. Como esse não havia sido retomado até o momento de finalização da 
coleta de informações empíricas para esta pesquisa, os professores continuaram realizando seu trabalho de forma individual e solitária, sem oportunidade de planejamento coletivo, que pudesse promover o crescimento da equipe de professores, por meio das discussões e reflexões e da formação em serviço.

No que se refere à compreensão do papel da Geografia na formação dos alunos, as respostas dos professores trazem a contradição entre formação para o mercado de trabalho e formação para a cidadania. Essa é expressa pela coexistência de concepções tradicionais e progressistas, na medida em que os argumentos dos professores transitam entre propostas ora são baseadas na concepção da Pedagogia Tradicional e ora nas concepções Progressistas. Assim, os professores alternam discursos de educação crítica e de educação tradicional. Um exemplo dessa situação é dado pela resposta ao principal papel da Geografia, que é "preparar o aluno para o mercado de trabalho". Nesse sentido, ao mesmo tempo em que demonstram discursos críticos referentes ao papel e a importância da Geografia na formação dos alunos, implementam ações pedagógicas que valorizam sobremaneira o livro didático e realizam atividades de cópias de textos, que são pouco significativas à reflexão sobre a realidade do aluno e sem nenhuma contribuição crítica à compreensão de seu lugar de vivência.

A atuação dos professores contrapõe e se destoa dos objetivos propostos pelos PCN e CM/EB-DF em relação à prática docente, na medida em que há a necessidade de fornecer e fortalecer, nos discentes, os instrumentos necessários para compreender e intervir na sua realidade social. Porém, na sua prática pedagógica, isso não ocorre. Assim, percebe-se que o papel da Geografia na formação dos alunos não é cumprido; as informações obtidas pelos questionários e entrevistas demonstram concepções confusas e destoantes daquelas que seriam adequadas a uma prática pedagógica que busca elevar o aluno à categoria de sujeito crítico e atuante em sua realidade social.

Pelas palavras dos professores fica evidenciado que o papel da Geografia é "preparar aluno para mercado de trabalho" (Prof.1), "identificar o mundo em que se vive" (Prof. 3), "trazer o que está fora da realidade deles para sua realidade" (Prof. 4). Esse discurso genérico, que oscila entre discurso crítico e um discurso tradicional, repercute diretamente no momento de se traduzir a concepção pedagógica em ação pedagógica adequada à formação da cidadania. 
Nos questionários, as respostas obtidas demonstram que o conteúdo de Geografia é desmotivador e superficial, a ponto de ser considerado como simples "informação" (Prof. 03). A esse respeito é interessante chamar a atenção para o fato de que formação é ato, efeito ou modo de formar, modo por que se constituiu uma mentalidade, um caráter (FERREIRA, 2010), Enquanto informação é ato ou efeito de informar, fatos conhecidos ou dados comunicados acerca de alguém ou algo. Então, o aprofundamento conceitual a partir do próprio conteúdo de Geografia, tem o potencial de ocasionar mudanças de comportamento nos indivíduos. Assim, se o professor considera a formação como informação, é compreensível que os conteúdos sejam desmotivadores e não despertem o interesse dos alunos.

Percebe-se que os professores de Geografia não fazem uso do lugar de vivência dos alunos. Desse modo, perdem a oportunidade de trabalhar questões inerentes a própria comunidade. Tal constatação é confirmada pelo fato de todos os professores não realizarem aulas de campo pelo Condomínio Sol Nascente, lugar dos alunos. A esse respeito é interessante observar que as respostas foram unânimes: "não realizam aula de campo, em virtude de pouco conhecimento acerca da comunidade, de um lado, e receio de violência, de outro".

Sobre as dificuldades encontradas pelos sujeitos professores para realizar seu trabalho foram relatadas causas externas à sala de aula como: falta de material didático, infraestrutura e estrutura precária, ausência de laboratório de informática falta de apoio da família, gestão ineficiente, desinteresse dos alunos, processo de migração constante, nível de escolaridade com defasagem escolar, baixo nível de escolaridade dos pais, baixo nível de leitura e escrita dos alunos que dificulta a aprendizagem e também a violência da comunidade que reflete na escola. E em decorrência disso a escola necessitou da presença permanente da Polícia Militar e ainda permanece em horários aleatórios até o momento no turno que compreende o Ensino Fundamental de 6으 ao 9ํano.

Podem-se apontar motivos e culpados para cada uma das dificuldades relatadas pelos professores do CEF-28. Porém, mais importante que isso é assumir que tais motivos são verdadeiros e interferem diretamente na qualidade de ensino, não somente da disciplina Geografia, como também em todas as disciplinas do currículo escolar e em todo o funcionamento da instituição. 
Esta pesquisa buscou, também, identificar as atividades utilizadas pelos professores em suas aulas. Nesse sentido, todos os pesquisados demonstraram pautar seu processo ensino-aprendizagem com base nas seguintes atividades: exercício do livro didático, cópias de textos, cópias de mapas, questionários. Tais atividades evidenciam uma maior preocupação com a variedade de noções, conceitos e informações, a serem apropriadas pelo aluno, em detrimento da formação do pensamento reflexivo. Essa postura, por sua vez, evidencia a preponderância de uma perspectiva tradicional sobre uma crítica.

Sobre a avaliação do aluno, os professores afirmam que os pontos mais importantes para serem avaliados referem-se à compreensão do conteúdo e sua memorização. Em nenhum momento houve considerações, acerca da reflexão sobre esses conteúdos. Isso pode ser considerado uma prática avaliativa estabelecida com base na Pedagogia Tradicional, onde a memorização do conteúdo é supervalorizada em detrimento da reflexão.

\subsection{Entrevistas}

A sistematização das entrevistas indicou similaridade com as respostas obtidas pelos questionários.

Em relação ao papel da Geografia observou-se a mesma dicotomia da formação pedagógica dos professores, traduzida pelo confronto entre educar para o mundo do trabalho ou educar para a cidadania. Do mesmo modo, observa-se a oscilação entre a Pedagogia Tradicional e Pedagogia Progressista, como se comprova pelas palavras de um dos professores entrevistados:

O papel da Geografia é preparar os alunos, né?!... a serem profissionais na área, né?! É... Educadores também! Preparar eles pra... pra ser educadores, para o mercado de trabalho; enfim, pra ter... pra obter uma vida melhor, né?! (PROFESSOR(a) 3, 2014, p. 1).

O papel da Geografia é de tentar situá-los, né?!... quanto os aspectos físicos, os aspectos humanos, né?!... dentro dos aspectos físicos, né?!... a questão do clima, do relevo, vegetação, hidrografia, dos seus aspectos econômicos, já passando pra parte de Geografia humana, fazendo uma correlação entre os aspectos físicos e os aspectos sociais e os aspectos econômicos, até mesmo os aspectos culturais, certo?!... da... do meio com a Geografia onde eles vivem! (PROFESSOR(a) 3, 2014, p. 3).

A Geografia, ela tem um papel importante de... de trazer... é... o aluno pra um... pra um plano crítico, né?! Identificar... a... o mundo em que ele vive e saber... a... criticar esse mundo, e saber perceber as relações que existem dentro dele, né?!... dentro da sociedade, pra compreender melhor as relações em que eles estão inseridos. (PROFESSOR(a) 3, 2014, p. 4). 
É a matéria que consegue integrar todos os conhecimentos de todas as áreas e trazer para o mundo real. Então, eu acho que o papel da Geografia na... na... na escola, para os meus alunos, é esse: tentar trazer o que está fora da realidade deles pra realidade... pra aprenderem a inter-relacionar essas realidades diferentes que existem! (PROFESSOR(a) 3, 2014, p. 6).

Em relação à importância da Geografia para os alunos, a análise das informações referentes às entrevistas, atesta que os professores consideram que a disciplina contribui para que o aluno efetue uma leitura crítica da realidade, como afirma um professor:

A importância da Geografia, ela está dentro desse contexto, né?!... de... inserir o aluno no mundo crítico; de perceber a relação sociedade-natureza e entre a sociedade em que ele está pra, talvez, até... construir um mundo melhor, daqui pra frente, já que eles são o futuro, né?! (PROFESSOR(a) 3, 2014, p. 4).

É importante ressaltar que os professores apresentam um discurso genérico, dentro do qual consideram que a Geografia ajudará o aluno em seu mundo local e na construção da sua cidadania. A despeito dessa afirmação, porém, tal intenção não se mostrou em sua prática pedagógica. Nesse sentido, tais discursos encobrem o fato de que, na prática, a matéria é considerada de pouca importância para vida, "é decoreba", e por isso os "alunos não se dedicam a ela:

(...) atualmente, ela ainda é vista como submatéria! Né?! Então, eles não dão muita importância... Não dão a importância à Geografia a mesma importância que eles dão à Matemática, ao Português, por exemplo! (PROFESSOR(a) 4, 2014, p. 6).

Os professores afirmam que os alunos não associam a disciplina ao seu dia-a-dia e por isso não conseguem compreender a importância da Geografia para suas vidas. Reclamam, ainda, não haver material didático na escola à disposição para as aulas. Sobre isso, compreende se que os professores não tem cumprido seu papel de trazer os conteúdos da Geografia para a vida do aluno, para que eles possam valorizá-la como um conteúdo importante e necessário as suas vidas.

A inserção do lugar dos discentes no contexto das aulas não é feito. Nesse sentido, ficou evidenciada a dificuldade dos entrevistados em compreender e relacionar qual a importância e a função social dos conteúdos de Geografia aos alunos. A consequência imediata disso aos alunos é a desmotivação e desinteresse pela Geografia, por parte dos alunos.

Pelas análises das entrevistas compreendeu-se que os professores valorizam a Geografia na formação dos alunos, como uma disciplina acadêmica, teórica e direcionada à 
apresentação de tópicos de forma "ideal", ou seja, são apresentados conteúdos sem uma problematização, que permita a associação entre o conteúdo e a realidade do lugar. A desconsideração dessa associação pode estar associada ao fato de $75 \%$ dos professores pesquisados não morarem e nem conhecerem o Sol Nascente, deslocando-se a escola apenas para trabalhar.

Embora os professores reconheçam que o ensino de Geografia possa contribuir para a formação dos alunos, observa-se, novamente, uma contradição entre seu discurso e sua prática pedagógica, pois essa se restringe ao uso do livro didático. Nesse sentido, o trabalho de mediação pedagógica a ser feito pelo professor incorporaria a responsabilidade de estabelecer correlações entre os conteúdos mais gerais, que retratam a Geografia do Brasil e do mundo, e o Sol Nascente.

Importante ressaltar que tais constatações evidenciam uma prática pedagógica tradicional, que não privilegia o processo de construção do conhecimento pelo aluno. Dessa forma, pode-se inferir, que o aluno não se sente motivado à aprendizagem, não se percebe no contexto dos conteúdos abordados, não desenvolve seu sentido de cidadania por meio da disciplina e não se reconhece como sujeito que integra uma coletividade, e assim, não constrói condições internas de participar das decisões para transformar sua realidade.

Esse mesmo processo acontece com o professor, que não sendo morador, distante da problemática social, econômica e geográfica do lugar, não consegue transcender as orientações e o conforto do livro didático, para elaborar um trabalho diferenciado com os alunos. Assim, o professor deixa de contribuir para uma aprendizagem que valorize os espaços de vivência, e desconsidera a luta por melhorias nas condições de vida da população com alto grau de vulnerabilidade social. Em consequência, não se contribui para o desenvolvimento da noção de cidadania.

\subsection{Análise Documental}

\subsubsection{PCN de Geografia}

A análise do PCN de Geografia revela que, pelo menos do ponto de vista legal, há uma preocupação com a formação da cidadania e a consideração do conceito de lugar, o que pode ser enquadrado como um avanço no tocante ao ensino, porque 
a Geografia é uma área de conhecimento comprometida em tornar o mundo compreensível para os alunos, explicável e passível de transformações. Neste sentido, assume grande relevância dentro do contexto dos Parâmetros Curriculares Nacionais, em sua meta de buscar um ensino para a conquista da cidadania brasileira. (PCN DE GEOGRAFIA, 1998, p.26).

A análise revelou, ainda, que os PCN's trazem orientações didáticas com objetivo de interferir diretamente na mudança e inovação das práticas pedagógicas dos professores, além de estabelecer orientações para a utilização do livro didático. Na realidade, porém, tais proposições não conseguem alcançar a prática dos professores, na medida em que esses não percebem que é possível incorporar temáticas locais aos processos de mediação pedagógica e à abordagem dos conteúdos. Desse modo, as orientações legais dadas pelos PCN's não se efetivam na prática e isso desencadeia a não consideração dos temas relativos ao Lugar Condomínio Sol Nascente. Em relação ao papel da Geografia, o PCN afirma que a aquisição de conhecimentos básicos de Geografia é importante para a vida em sociedade, principalmente no que se refere ao desempenho das funções de cidadania, por meio do conhecimento das características sociais, culturais e naturais do lugar onde vive o aluno. Tal documento, porém, ao especificar conteúdos a serem trabalhados, não indicam um momento para se trabalhar o Lugar. Nesse sentido, nos conteúdos propostos identificase uma orientação ao trabalho nas escalas nacional e global, em detrimento da escala local.

Pode-se afirmar, ainda, que o PCN de Geografia do Ensino Fundamental apresenta objetivos e expectativas de que os alunos adquiram competências e comportamentos com a construção da inter-relação entre cidadania e lugar. Entretanto, para que isso ocorra é necessário trabalhar a categoria cidadania em escala local, para depois ampliar conteúdos para escala nacional e global. Como resultado, constata-se a supressão da perspectiva local e, nesse contexto, perde-se a oportunidade de construir a noção de cidadania a partir do Sol Nascente. Além disso, a proposição de lugar nesse caso associa-se à escala nacional, o que dificulta a identificação e compreensão dos processos globais, que se materializam no lugar.

\subsubsection{CM/EB-DF}

O CM/EB-DF apresenta eixos transversais com ênfase à cidadania, com objetivos sucintos para cada ano; especificam, de forma breve, os conteúdos a serem trabalhados e inovam pela proposição dos eixos integradores Ludicidade e Letramento do $6^{\circ}$ ao $9^{\circ}$ ano. Nesse sentido a maior inovação é demonstrada por meio do eixo Letramento, que aponta a preocupação relativa à aprendizagem e desenvolvimento da leitura e a escrita. 
Nessa pesquisa optou-se por analisar os conteúdos de cada ano, inter-relacionandoos com as possibilidades de trabalho pedagógico a partir das categorias Cidadania e Lugar.

A análise dos conteúdos de cada ano revelou que à medida que aumenta a faixa etária dos alunos, diminui o número de conteúdos onde se podem inserir as categorias Cidadania e Lugar, conforme pode-se observar no quadro 9 do item 1.1.2 desta pesquisa. Tal diminuição é decorrente do aumento do nível de complexidade dos conteúdos, de um lado, e das questões relativas às temáticas de ordem global.

Os conteúdos do 9a ano o CM/EB-DF propõem conteúdos que não fazem parte da vida cotidiana do aluno. Nesse sentido, não propicia oportunidade de inserção daquelas categorias, tão importantes aos jovens alunos, para se perceberem como sujeitos de um espaço que, no local, expressa a materialização das situações de ordem global.

\subsubsection{PPP}

O PPP constitui-se um documento básico da escola, que é utilizado por seus professores para a elaboração de seu Plano de Ensino, conforme atestaram suas próprias respostas. Porém, a análise desse documento revelou que ele é inacabado, pois suas considerações referem-se aos anos iniciais de escolarização, até o $3^{\circ}$ Ano. Nesse sentido, não existem considerações que contemplem os anos finais, o que evidencia uma lacuna na orientação ao expressivo número de alunos (aproximadamente 1400) desses níveis de escolarização. Tal fato evidencia a perda de oportunidade de registrar uma orientação específica aos professores, para o trabalho com jovens em áreas de vulnerabilidade social, de um lado, e a reafirmação do papel social da escola frente a essa comunidade.

Ciente dessa lacuna buscou-se nas informações existentes, relativas ao $1^{\circ}, 2^{\circ}$ e $3^{\circ}$ ano do Ensino Fundamental, a identificação de ideias e proposições que permitissem um trabalho pedagógico interligado à cidadania e lugar. Nesse sentido, constatou-se que essa possibilidade aparece em dois objetivos específicos, que se referem à necessidade de "Resgatar valores de cidadania, atitudes de solidariedade, cooperação e respeito; Conscientizar a comunidade quanto à preservação do ambiente no qual está inserida".

Com exceção desses objetivos, não se vislumbra nenhuma outra possibilidade de abordagem das categorias cidadania e lugar nos documentos em questão. 


\subsubsection{PE/LD}

Conforme explicitado anteriormente, não foi realizada análise dos planos de ensino dos professores, conforme previsão metodológica, pelo fato de não terem sido elaborados. Consequentemente, por essa via, não foi possível identificar as atividades realizadas pelos professores, que possibilitassem o trabalho com as categorias em questão.

Entretanto, e considerando-se que as aulas são dadas, a despeito de não terem sidos planejadas por meio de um PE, emergem algumas indagações: os Planos de Ensino existiram em algum momento ou estão em construção? Como o grupo de professores de Geografia seleciona os conteúdos importantes ao trabalho pedagógico? Seria o livro didático o principal norteador da seleção dos conteúdos para a ação pedagógica?

Sabe-se que as orientações dos PCN's de Geografia embasam o livro didático. Nesse sentido, pode-se afirmar que de uma forma indireta são os conteúdos elencados no livro didático, que direcionam a ação pedagógica dos professores. É importante lembrar que o Currículo em Movimento da SEE-DF é um documento novo, construído processualmente durante o ano de 2012 e 2013 e foi apresentado à comunidade escolar nos anos de 2013 e 2014. Portanto, ainda está em vias de internalização pelos professores da rede pública de ensino. Desse modo, a principal orientação ao planejamento das aulas ainda é o livro didático.

Nessa perspectiva, e para superar o problema da ausência dos PE, optou-se pela análise das proposições dos LD's adotados pelos professores do CEF-28, no ano de 2013.

Assim a análise revelou que há grande similaridade dos conteúdos estabelecidos pelos LD's, com os conteúdos propostos pelos PCN de Geografia; ambos não consideram um trabalho pedagógico com base a categoria Lugar, no sentido desse expressar o local onde está inserida a escola. Porém, apresentam conteúdos amplos, em escalas que são distantes da vida do aluno, voltados à construção de uma noção de cidadania global, isto é, um currículo que propõe conteúdos direcionados para a aprendizagem de contextos de um Brasil e de um mundo muito distantes da categoria Lugar. Compreendeu-se cidadania global com estudos com base num currículo muito aleatório a vida do aluno e que nem sempre dá ao professor a capacidade de inter-relacionar esses conteúdos com a vida local. 


\section{Considerações Finais e Recomendações}

Esta pesquisa objetivou investigar a prática dos docentes de Geografia do CEF-28 de Ceilândia, para compreender se o papel formativo desta disciplina estava sendo cumprido. Nesse sentido, buscou fundamentação em autores que teorizam a respeito do ensino de Geografia e também em documentos oficiais do Brasil e do Distrito Federal, a saber: PCN de Geografia, CM/EB-DF, PPP e PE. Na inexistência do PE, foram analisados os livros didáticos escolhidos e adotados pelos professores da escola. Tal aporte documental foi direcionado à compreensão referente ao ensino de Geografia. A pesquisa empírica contextualizou o lugar da pesquisa, considerando-o como área de vulnerabilidade social, por se inserir em um contexto de favelização. Desse modo, assumiu-se que tal circunstância é relevante ao processo de ensino/aprendizagem e nesse contexto, a perspectiva do lugar assumiu significativa importância.

Desse modo, o lugar - CEF-28 da Ceilândia, situado nas proximidades do Condomínio Sol Nascente apresenta particularidades: uma região em constantes conflitos sociais, tais como grilagem e comercialização ilegal da terra, construções de moradias sobre as nascentes e em Áreas de Preservação Permanente. Diante das tentativas de expansão das invasões o Governo intervém com a retirada dos moradores e, às vezes, com uso da força policial. Tal situação interfere diretamente no fazer pedagógico da escola e, por conseguinte, na atuação do professor.

O processo de construção e implementação do CEF-28 de Ceilândia, num contexto de ausência e/ou insuficiência de infraestrutura física e humana da localidade onde está inserida a escola, repercutiu no agravamento da crise de qualidade de ensino naquela instituição, na medida em que houve alta rotatividade de profissionais. Além disso, os professores desse centro demonstraram contradições em suas práticas pedagógicas, ao mostrar um discurso progressista, conjugado com práticas tradicionais. Entretanto, a responsabilidade desses frente a este problema, pode ser minimizada em virtude da própria rotatividade de profissionais, onde se enquadram os supervisores pedagógicos, e ainda, a ausência de um processo de coordenação pedagógica e outros momentos de construção coletiva propiciada pela escola.

Assim, para essa escola pesquisada, valem ressaltar a importância de um processo efetivo de coordenação com a participação dos professores, planejamentos das aulas, 
valorização do lugar pelos docentes, realização de projetos e aulas de apoio nos contraturnos.

Do ponto de vista dos alunos, infere-se que esse cenário apenas corrobora com práticas tradicionais, repetitivas, superficiais e desmotivadoras, portanto, que pouco contribuem para a formação crítica, participativa.

Nessa proposição, é necessário que os professores dessa instituição que foram pesquisados, atualizem as suas práticas pedagógicas com cursos de formações continuadas para contribuir numa formação progressista e critica.

Observou-se que os conteúdos apresentados nos PCN, CM/EB-DF e nos livros didáticos apresentam, majoritariamente, temas e conteúdos relacionados a uma escala nacional e/ou global, que dificultam a identificação de sua materialização em escala local. Nesse sentido, os conteúdos aprendidos tornam-se distantes de vida do aluno, com poucos significados à construção de sua noção de cidadania. Importante ressaltar que esse é o momento em que o trabalho de mediação pedagógica do professor é mais relevante, pois o papel da mediação implica que o professor proponha atividades para inter-relacionar, interligar e interdisciplinar os conteúdos propostos no currículo, com os conteúdos que fazem parte da formação cidadã e, também, que possibilitem a construção da identidade vinculada ao local de vivência do aluno.

Esta pesquisa apontou, ainda, que o ensino/ aprendizagem da disciplina Geografia no CEF-28 da Ceilândia não tem alcançado seu objetivo primordial, que é a formação cidadã e a valorização da identidade junto ao lugar. Tal fato é comprovado pela inexistência de diálogo sobre um projeto de ensino para a disciplina, que enfoque o lugar com toda a sua problemática. Essa ausência é decorrente, provavelmente, da inexistência de oportunidades para construção coletiva do PPP, que poderia fortalecer o papel articulador da disciplina frente à comunidade Sol Nascente. Do mesmo modo é absurda a ausência de Planos de Ensino, pois as ações pedagógicas demandam planejamento e discussão. No presente caso, constatou-se que o planejamento da disciplina é estabelecido pelas orientações postas pelo livro didático adotado pelos professores. Assim, apesar das orientações da SEE-DF para realização de planejamento coletivo na escola, com periodicidade semanal, professores e equipe pedagógica seguem trabalhando solitários com o livro didático, que pouca ou nenhuma relação tem com o Lugar Sol Nascente. Em consequência, o aluno do CEF-28 de Ceilândia, por meio das aulas de Geografia, pouca motivação terá para conhecer 
seu lugar de vivência, como também é provável que não consiga estabelecer a ligação entre o seu dia a dia e os conteúdos ministrados, por serem amplos e distantes da realidade vivenciada pelos alunos.

A pesquisa mostrou que a equipe pedagógica e os professores lotados no CEF-28 de Ceilândia não pertencem à comunidade do Sol Nascente, por não serem moradores deste lugar. Nesse sentido, constatou-se que o conhecimento do lugar pelos professores é insignificante, na medida em que se deslocam para o Sol Nascente apenas para ficar dentro dos muros da escola. Desse modo, se os professores não conhecem a comunidade, não sabem explicar as características da vulnerabilidade social da região, como irão mediar com elementos da vida cotidiana dos alunos?

Para o CEF-28 de Ceilândia e lugares de vulnerabilidade social são necessários que os professores envolvidos no processo educativo não faça a desqualificação dos lugares dos alunos, e que os mesmos utilizem essas situações como ferramentas educativas para elevar a formação cidadão critica dos envolvidos. Também é necessário que os gestores das instituições façam apresentações das dificuldades e potencialidades que o lugar oferece para os novos professores.

A alta rotatividade de profissionais no CEF-28 de Ceilândia tem se constituído um problema, pois a maioria dos profissionais que chega à escola se apresenta para o Concurso de Remanejamento ao final do ano. Pela pesquisa pode-se identificar que os professores se sentem desmotivados com o lugar, em virtude das dificuldades relativas à vulnerabilidade social da região, com as restrições ao trabalho ali realizado e esperando o fim do ano para sair dali, em busca de um lugar melhor, com maior segurança e outro contexto de trabalho.

Enquanto a escola não tiver um trabalho de coordenação pedagógica consistente, no sentido de assegurar um melhor desempenho pedagógico aos professores, esse problema vai continuar. Assim, a SEE-DF precisa intervir neste processo, participando e auxiliando de formas diferenciadas na construção do processo educativo das escolas situados em lugares de vulnerabilidade social.

Outro problema decorrente da rotatividade de profissionais no CEF-28 de Ceilândia, relativo às dificuldades que interferem na prática pedagógica dos professores, refere-se à dificuldade para constituir corpo técnico efetivo, que possa continuar a proposição do PPP. Do mesmo modo, quaisquer outras ações pedagógicas, ficam reféns do processo de 
descontinuidade e ruptura, o que contribui para a não consolidação da identidade da própria escola e seu papel frente ao contexto social onde está inserida. Nesse contexto, é importante ressaltar, que a escola apresenta um número expressivo de pessoas que circulam diariamente em suas dependências - pais, alunos, visitantes - concomitante a um número diminuto de profissionais para atendê-los. Assim, a equipe composta pela Direção, Supervisão Escolar e Coordenadores está sempre lidando com situações urgentes tais como, disciplina e mediação de conflitos entre o grande número de alunos, crianças e adolescentes doentes; conflitos entre adolescentes, pais, professores e alunos e, também, atendimento das demandas da Secretaria de Educação, como reuniões nas Coordenações Regionais de Ensino e na SEE-DF, organização da merenda escolar, compras de materiais pedagógicos, entre outros. Nessa perspectiva, resta pouco tempo para a realização de projetos educacionais e de acompanhamento da prática pedagógica dos professores dessa instituição. Consequentemente, nessa Instituição, as questões de cunho urgente antecedem as de cunho pedagógico.

Diante do exposto, pode-se afirmar que esta pesquisa revelou que a dura realidade da jornada profissional vivida pelos professores do CEF-28 constitui-se um problema à prática pedagógica e contribui para que o ensino de Geografia não cumpra seu papel.

Por fim, compreendeu se que é complexo desvencilhar o fazer do professor do lugar onde ele está inserido e da sua (não) formação crítica. Nesse sentido, professor só poderá tornar-se efetivamente crítico, se conciliar na sua prática pedagógica a tríade cidadãoidentidade-lugar, para que se perceba participante do espaço em que vive e seja autor das transformações sociais que o lugar exige. 


\section{REFERÊNCIAS}

ANDRADE, Maria Margarida de. Introdução à metodologia do trabalho científico: elaboração de trabalhos na graduação. 10. ed. - São Paulo: Atlas, 2010.

BAECKER, Ingrid Mariane et al. Projeto construindo um planejamento para a disciplina Educação Física. In: Anais do X Congresso Brasileiro de Ciência do Esporte. Renovações, modismo e interesse do CBCE, Goiânia-GO, 1997. p. 146-154.

Boiko, Vanessa Alessandra Thomaz \& Zamberlan, Maria Aparecida Trevisan, A perspectiva sócio-construtivista na psicologia e na educação: o brincar na pré-escola. Psicologia em Estudo, Maringá, v. 6, n. 1, p. 51-58, jan./jun. 2001.

BRANDÃO, Carlos Rodrigues. O que é educação: Brasiliense, 1985, (Coleção Primeiros Passos; 45).

BRASIL, Lei no 9.394, de 20 de dezembro de 1996. Estabelece as diretrizes e bases da educação nacional. Diário Oficial da União. Brasília, 1996.

B823p Brasil. Secretaria de Educação Fundamental. Parâmetros curriculares nacionais:

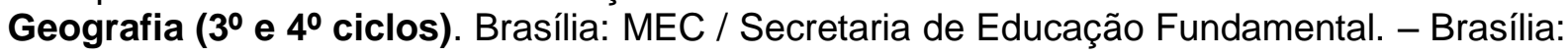
MEC/SEF, 1998. 126p.

B823p Brasil. Secretaria de Educação Fundamental. Parâmetros curriculares nacionais: terceiro e quarto ciclos do ensino fundamental: introdução aos parâmetros curriculares nacionais / Secretaria de Educação Fundamental. - Brasília: MEC/SEF, 1998. $174 \mathrm{p}$.

B823p Brasil. Secretaria de Educação Fundamental. Parâmetros curriculares nacionais: história, geografia / Secretaria de Educação Fundamental. - Brasília: MEC/SEF, 1997. $166 p$.

B823p Brasil. Secretaria de Educação Fundamental. Parâmetros curriculares nacionais: terceiro e quarto ciclos: apresentação dos temas transversais / Secretaria de Educação Fundamental. - Brasília: MEC/SEF, 1998. 436 p.

BAUER, M. W. \& GASKELL, G. Pesquisa qualitativa com texto, imagem e som: um manual prático. Petrópolis: Vozes, 2002.

CALLAI, Helena Copetti. Aprendendo a ler o mundo: a Geografia nos anos iniciais do ensino fundamental. Cad. Cedes, Campinas, vol. 25, n. 66, p. 227-247, maio/ago. 2005.

CALLAI, Helena Copetti. Estudar o lugar para compreender o mundo. In: CASTROGIOVANNI, Antônio Carlos (org.). Ensino de Geografia: Práticas e Textualizações no Cotidiano. Porto Alegre/RS: Ed. Mediação, 2000, p.83-134.

CARDOSO, Carlos Augusto de Amorin \& MEDEIROS, Lucy Sátyro de. A Geografia escolar nas várias perspectivas $10^{\circ}$ Encontro Nacional de Prática de Ensino em Geografia. 30 de agosto a 02 de setembro de 2009, Porto Alegre - RS.

CARLOS, Ana Fani Alessandri. O lugar no/do mundo. São Paulo: FFLCH, 2007. 
CAVALCANTI, Lana de Souza. "Concepções de Geografia e de Geografia Escolar no mundo contemporâneo". In: A Geografia Escolar e a Cidade: Ensaio sobre o ensino de Geografia para a vida urbana cotidiana. Campinas: Papirus, 2008, p.15-37.

Lana de Souza. A Geografia Escolar e a Sociedade Brasileira Contemporânea. In: TONINI, Maria Ivaine; et al (Org.) $\mathbf{O}$ ensino de geografia e suas composições curriculares. Porto Alegre: UFRGS, 2011. p. 77-96. $155-173$

Lana de Souza. O ensino de Geografia Escolar. Campinas: Papirus, 2012. p.

Lana de Souza. In: Geografia, Escola e Construção de Conhecimentos. Campinas: Papirus, 2006, p. 137-166.

Lana de Souza. A Geografia Escolar e a Cidadania: Ensaios sobre o Ensino de Geografia para a vida urbana cotidiana. 3. ed. - Campinas: Papirus, 2010.

CODEPLAN-DF Coletânea de informações socioeconômicas da região administrativa RA IX-Ceilândia Brasília, maio de 2007, pág. 08 - 11.

Pesquisa Distrital por Amostra de Domicílios - Setores Habitacionais Pôr do Sol e Sol nascente - PDAD 2013.

Distrito Federal - Síntese de Informações Socioeconômicas - SIS 2010.

Distrito Federal. Secretaria de Estado de Educação. Portaria № 254 de 01 de outubro de 2013. Brasília: Diário Oficial do Distrito Federal, ano XLIII № 204, terça-feira, 01 de Outubro de 2013.

Secretaria de Estado de Educação. Portaria no 12, de 24 de Janeiro de 2014. Brasília: Diário Oficial do Distrito Federal, ano XLIII no 21, terça-feira, 28 de Janeiro de 2014.

Secretaria de Estado de Educação. Diretrizes Pedagógicas Secretaria de Estado de Educação do Distrito Federal. Brasília, 2009/2013.

DINIZ FILHO, Luís Lopes Fundamentos epistemológicos da geografia. 1. ed. Curitiba: IBPEX, 2009 (Coleção Metodologia do Ensino de História e Geografia, v. 6), p. 84-87.

DISTRITO FEDERAL, Lei 4.751, de 7 de fevereiro de 2012, Dispõe sobre o Sistema de Ensino e a Gestão Democrática do Sistema de Ensino Público do Distrito Federal. Brasília: Diário Oficial do Distrito Federal, ano XLIII № 28, terça-feira, 07 de Fevereiro de 2012.

FERREIRA, Aurélio Buarque de Holanda. Mini Aurélio: o dicionário da língua portuguesa / 8. Ed. - Curitiba: Positivo, 2010. 960 p.: i.

FERREIRA, Jhônatas Silva \& MOREIRA, Rogério Rebouças. Brasília: um lugar central. 1ำ Seminário Dinâmica Econômica e Desenvolvimento Regional. Universidade Federal do Triângulo Mineiro - UFTM, Uberaba-MG. 2012.

FERREIRA, Luiz Felipe. Acepções recentes do conceito de lugar e sua importância para o mundo contemporâneo. Revista Território, Rio de Janeiro, ano V, n" 9, pp. 65.83, jul./dez., 2000. 
FERREIRA, Sueli. 0 ensino das artes: construindo caminhos. $3^{a}$ edição, Campinas: Papirus, 2001.

FRANCISCHETT, M. N. A cartografia no ensino de Geografia: construindo caminhos do cotidiano. São Paulo: UNICENTRO-UNICAMP, 2002.

Freire, Paulo. Pedagogia do oprimido. 11. ed. Rio de Janeiro: Paz e Terra, 1982.

GALVÃO, I. R. \& Bezerril, K. O. Friedrich Ratzel: uma Análise da Difusão de suas Ideias no Contexto da Geografia Brasileira. Sociedade e Território, Natal, v. 25, no 1, p. 19 - 29, jan./jun. 2013.

GIARDINO, Claudio... [et al].- Geografia nos dias de hoje. $6^{\circ}, 7^{\circ}, 8^{\circ}$ e $9^{\circ}$ ano. $1^{\circ}$ ed. - São Paulo: Leya, 2012. - (Coleção nos dias de hoje).

GIL, Antonio Carlos. Como elaborar projetos de pesquisa. 4. ed. São Paulo: Atlas, 2008.

GOMES, P. C. da C. Geografia e Modernidade. Rio de Janeiro: Bertrand Brasil, 1996.

GÔNGORA, Francisco Carlos, Tendências Pedagógicas na Pratica Escolar, Edições Loyola. São Paulo. 1985.

HAGUETTE, Teresa Maria Frota. Metodologias qualitativas na Sociologia. $5 a$ edição. Petrópolis: Vozes, 1997.

HURTADO, Melcherst; GUILLERMO, Jonhann Gustavo. O ensino da Educação Física, uma abordagem didático metodológica. Porto Alegre: Prodil, 1988.

INSTITUTO BRASILEIRO DE GEOGRAFIA E ESTÁTISTICA - IBGE. Resultado da Amostra do Censo demográfico, 2010. Disponível em: http://www.ibge.gov.br/cidadesat/ Acessado em 21/08/2014.

KAERCHE, Nestor André. Já é outubro! Te amo ainda mais! Eu desejo que você deseje me ouvir!. In: Pereira, Marcelo Garrido (Org). La opacidade del paisaje: formas, imágenes y tempos educativos. Porto Alegre: Imprensa Livre, 2013, p. 77-92.

LEFÈBVRE, Henri. La presénce et l'aucence contribution à la théorie de dês representations. Paris: Casterman, 1980 in CZESZAK, Wanderlucy A. Corrêa. O Conceito de Representação de Henri Lefebvre e a Questão do diálogo na relação professor/aluno. Revista Internet, ano III, nº 8.

LEITE, Cristina Maria Costa. Educação no contexto contemporâneo: as possibilidades do Lugar. V Colóquio Internacional "Educação e Contemporaneidade" São CristovãoSE/Brasil 21 a 23 de Setembro de 2011.

Cristina Maria Costa. Geografia no Ensino Fundamental. Espaço \& Geografia, Vol.5, № 2 (2002), 245:280.

LESTEGÁS, Francisco Rodríguez. A construção do conhecimento geográfico escolar: do modelo transpositivo à consideração disciplinar da Geografia. In: CASTELLAR, Sônia M. Vanzella. Munhoz, Gislaine, Batista (Orgs). Conhecimentos escolares e caminhos metodológicos. São Paulo: Xamã, 2012, p.13-27. 
LIBANEO, José Carlos. Didática. São Paulo: Cortez, 1994.

LOPES, Antonia Osima. Planejamento do ensino numa perspectiva crítica de educação. In: VEIGA, Ilma Passos Alcântara (Cood). Repensando a didática. Campinas: Papirus, 1991. p. 41-52.

LUDKE. Menga \& Marli E.D.A. André. Pesquisa em educação: abordagens qualitativas São Paulo: EPU, 1986. (Temas básicos de educação e ensino).

MARCONI, Marina de Andrade \& LAKATOS, Eva Maria. Fundamentos de metodologia científica. 7. ed. - São Paulo: Atlas, 2010.

MARIN, A. J. Educação Continuada: Introdução a uma análise de termos e concepções. Cadernos CEDES n. 36, Papiru. 1995.

MARQUES, Juracy C. A aula como processo: um programa de auto ensino. Porto Alegre: Globo, 1979.

MARTINEZ, Maria Josefina; LAHORE, Carlos E. Oliveira. Planejamento escolar. São Paulo: Saraiva, 1977.

MEDEIROS, Lucy Satyro de. O Currículo escolar de Geografia e a construção do conhecimento: um olhar para a prática pedagógica do professor de Geografia, Pernambuco. 2010. Dissertação (mestrado) - Programa de Pós-Graduação em Geografia. Universidade Federal de Pernambuco, João Pessoa-PB.

MIZUKAMI, Maria da Graça Nicoletti. Ensino: as abordagens do processo. São Paulo: EPU, 1986. (Temas básicos da educação e ensino).

MORAES, Antonio Carlos Robert. A Antropogeografia de Ratzel: indicações. In: Ratzel. MORAES, Antonio Carlos Robert (Org.). São Paulo: Editora Ática, pp. 07-27, 1990. 200p.

MORAES, Carolina Roberta. Motivação do aluno durante o processo de ensino aprendizagem. IN: Revista eletrônica de Educação. Ano I, №. 01, ago. / dez. 2007.

MORELLI, Ana L. F. Correio Braziliense: 40 anos - Do pioneirismo à consolidação, Distrito Federal. 2002. Dissertação (mestrado) - Programa de Pós-Graduação em Comunicação. Universidade de Brasília, Brasília-DF.

PAGNI, Pedro Ângelo. Do manifesto de 1932 a construção de um saber pedagógico: ensaiando um diálogo entre Fernando de Azevedo e Anísio Teixeira. ljui: Ed. UNIJUí, 2000. - 344 p. (Coleção fronteiras da educação).

PALACIOS, G.A. Perguntas autoritárias: a questão do método, as monografias e o filosofar. Educação e Filosofia, Uberlândia, v. 22, n. 44, p. 101-114, jul. / dez. 2008.

PAVIANI, A. A realidade da metrópole: mudança ou transformação na cidade. In: Paviani, Aldo. (Org.). Brasília: Moradia e Exclusão. 1 ed. Brasília: Editora UnB, 1996, v. 1, p. 213-229.

PONTUSCHKA, Nídia Nacib; PAGANELLI, Tomoko lyda; CACETE, Núria Hanglei. Para ensinar e aprender geografia. 3ed, São Paulo: Cortez, 2009. p. 9-383. 
PILETTI, Claudino. Didática geral. São Paulo: Ática, 1990.

REIS, L.C \& SILVA, A.D. Projeto de prevenção de uso de drogas do CEF-28 de Ceilândia-DF, p. 1-15, 2013.

RELPH, E. As bases fenomenológicas da Geografia. Geografia. Rio Claro, v. 4, n. 7, p. 125, abr. 1979.

RELPH, Edward. Place and placelessness. London: Pion. 1980, p. 41 apud FERREIRA, 2000: 68 .

REZENDE FILHO, J. R. G. Área e disposição do Centro de Ensino Fundamental 28 de Ceilândia. Departamento de Geografia da Universidade de Brasília-UnB. Brasília, 2014.

ROCHA, G.O.R. A trajetória da disciplina geografia no currículo escolar brasileiro (1837-1942). 1996. 297f. Dissertação (Mestrado em Educação: supervisão e currículo) Pontifica Universidade Católica de São Paulo, São Paulo, 1996.

SANTOS, Ricardo Fideles dos. 0 acesso a moradia por famílias de baixa renda sem respaldo das políticas de habitação do governo do Distrito Federal: uma abordagem do Núcleo Habitacional Sol Nascente - Brasília: UnB, 2010.

SANTOS, Milton. Por uma outra globalização: do pensamento único à consciência universal / Rio de Janeiro: Record, 2000.

SAVIANI, Dermeval. Tendências e correntes da educação brasileira. MENDES, D. T. (Coord.) Filosofia da Educação Brasileira. 3 ed. Rio de Janeiro: Civilização Brasileira, 1987.

SEAA. Mapeamento Institucional do Centro de Ensino Fundamental 28 de Ceilândia, Brasília: 2014 (mimeo.).

SILVA, Ernesto. História de Brasília: Um Sonho, Uma esperança, Uma Realidade. Brasília: CDL, 1983.

SOUSA NETO, M. F. O Compêndio Elementar de Geographia Geral e Especial do Brasil. Terra brasilis, Rio de Janeiro, v. 1, n. 1, p. 08-51, 2000.

STRAFORINI, R. Ensinar geografia nos anos iniciais: o desafio da totalidade mundo. Dissertação (Mestrado). Instituto de Geociências, Universidade Estadual de Campinas, Campinas. 2001. $155 \mathrm{fls}$.

TUAN, Yi Fu . Espaço e lugar: a perspectiva da experiência. São Paulo: DIFEL, 1983.

Topofilia: Um estudo da percepção, atitudes e valores do Meio Ambiente. Tradução: Lívia de Oliveira, São Paulo: Difel, 1980.

TURRA, Clódia Maria Godoy et al. Planejamento de ensino e avaliação. Porto alegre: Sagra, 1995.

VEIGA, IIma P.A. (org.) O Projeto Político Pedagógico da Escola: Uma construção possível. $11^{\underline{a}}$ ed. Campinas, Papirus, 2000. 
VESENTINI, José William. O ensino de Geografia no Brasil: uma perspectiva histórica. In: VESENTINI, José William (Org.). 0 ensino de Geografia no século XXI. São Paulo: Papirus, 2004. p.187-218.

WETTSTEIN, G. Subdesenvolvimento e Geografia. São Paulo: Contexto, 1992.

YIN, R.K. Estudo de caso: planejamento e métodos. 3. ed. Porto Alegre: Bookman, 2005.

\section{CONSULTAS ELETRÔNICAS}

Blogspot. Disponível em: <http://hudsongiovanni.blogspot.com> Acesso em 28 de Novembro de 2014.

Editora Saraiva. Disponível em: $\quad<$ http://sites.editorasaraiva.com.br/portalgeografia /default.aspx?mn=184\&c=199\&s=0\&friendly=textos-de-apoio $>$ Acesso em 28 de Novembro de 2014

GADOTTI, Moacir. "Nós podemos reinventar o mundo" - Entrevista concedida a Revista Nova Escola, Novembro de $1993 . \quad$ Disponível em: http://acervo.paulofreire.org/xmlui/bitstream/handle/7891/1414/FPF OPF 07 005.pdf acessado em 09/02/2015.

Issuu. Disponível em: <http://issuu.com/sedf/docs/4-ensino-fundamental-anos-finais $>$ Acesso em 30 de Novembro de 2014.

Laptop. Disponível em: <http://wiki.laptop.org/go/Atividades de Geografia para $1^{\circ}$ e $2^{\circ}$ ciclos $>$ Acesso em 28 de Novembro de 2014.

Ministério da Educação. Disponível em: <http://portal.mec.gov.br/seb arquivos/pdf/geografia.pdf> Acesso em 28 de Novembro de 2014.

Sinpro DF. Disponível em: <http://www.sinprodf.org.br/wp-content/uploads/2014/01/ PORTARIA-№-12 do-dia-24.01.14.pdf> Acesso em 25 de Novembro de 2014.

Unicamp. Disponível em: <http://www.lite.fe.unicamp.br/papet/2003/ep145/pesq.htm> Acesso em 28 de Novembro de 2014.

Webartigos. Disponível em: <http://www.webartigos.com/artigos/a-educacao-ambiental-noensino-da-geografia/50506> Acesso em 28 de Novembro de 2014. 


\section{ANEXO 1}

\section{QUESTIONÁRIO}

1) Onde você nasceu?

2) Onde você mora?

3) Qual é o seu tempo de serviço na escola?

4) Qual é o seu tempo de experiência com a educação?

5) Qual a sua situação junto a Secretaria de Educação?

( ) Efetivo

( ) Contrato Temporário

6) Qual é a sua formação?

( ) Bacharel em Geografia - (especificar local de graduação)

( ) Licenciado - (especificar local de graduação)

( ) Outro - (especificar curso e local de graduação)

( ) Pós graduação - (especificar curso e local de graduação)

7) Qual é o papel da Geografia na formação de seus alunos?

8) Que importância possui a Geografia para seus alunos?

9) Que problemas você identifica nas relações de ensino/aprendizagem em Geografia?

( ) infraestrutura precária da escola

( ) inexistência de material didático específico (mapas, globos, bússolas)

( ) inexistência de laboratório

( ) laboratório de informática inadequado ao uso

( ) alunos carentes

( ) gestão ineficiente

( ) Outros (especificar) 
10) Como você insere o lugar de seus alunos no contexto de suas aulas?

11) O que você consulta para elaborar seu plano de ensino?

( ) Diretrizes Curriculares Nacionais

( ) Parâmetros Curriculares de Geografia

( ) Currículo em movimento da Educação Básica

( ) Projeto Político Pedagógico CEF-28 de Ceilândia

( ) Livro didático

( ) Outros (especificar)

12) Quais destas atividades você utiliza em suas aulas?

( ) Exercício no livro didático

( ) Leitura no livro didático

( ) Arguições

( ) Questionários

( ) Análises de músicas

( ) Análises de filmes

( ) Análises de obra de arte

( ) Atividade em grupo

( ) Atividades individuais

( ) Análises de mapas

( ) Produção de textos

( ) Cópias

( ) Construção de legendas

( ) Construção de gráficos

( ) Cópias de mapas

( ) Análises de gráficos

13) Para você qual é o ponto mais importante na avaliação do aluno?

( ) Memorização do conteúdo

( ) Compreensão do conteúdo

( ) Memorização do texto do livro didático 
( ) Compreensão do texto do livro didático

14) Você segue fielmente o livro didático?

( ) Sim

( ) Não

( ) Em parte

15) Você organiza aula de campo pelos setores onde os alunos moram?

( ) Sim

( ) Não

16) Quais os instrumentos de avaliação abaixo você utiliza em sua rotina docente?

( ) Provas objetivas

( ) Provas subjetivas

( ) Arguições orais

( ) Trabalhos em grupos

( ) Pesquisa de campo

( ) Relatórios

( ) Outros (especificar) 


\section{ANEXO 2}

\section{DE C L A R A Ç Ã O}

Declaro, para os devidos fins, ter ciência que as entrevistas concedidas a Antonio Dias da Silva, correspondem aos procedimentos de coleta de dados para sua pesquisa de mestrado, ora em curso, no Departamento de Geografia da Universidade de Brasília.

Nesse sentido, tenho conhecimento que a proposta de estudo foi submetida à direção do CEF-28, e foi aprovada por não se constituir prejudicial ao bom andamento dos trabalhos dos professores envolvidos, como também não apresentar possibilidade de danos à imagem do professor e da escola.

Por fim, atesto que aprovo a transcrição das conversas gravadas, desde que preservada a identidade do professor no computo final das análises.

Nome:

Assinatura: 